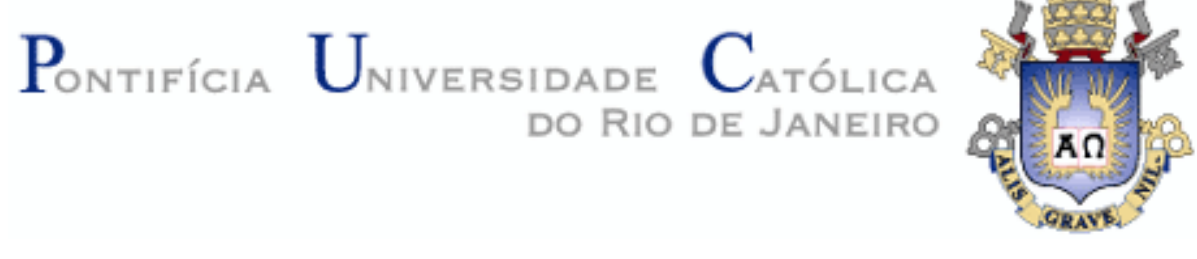

Andréa de Melo Cassinelli

\title{
Estruturação e Financiamento da Indústria Cinematográfica Brasileira: a ambição de uma trajetória autossustentável
}

Dissertação de Mestrado

Dissertação apresentada como requisito parcial para obtenção do grau de Mestre pelo Programa de Pós-Graduação em Engenharia de Produção do Departamento de Engenharia Industrial da PUCRio.

Orientador: Prof ${ }^{a}$. Fernanda Maria Pereira Raupp

Rio de Janeiro

Outubro de 2012 


\title{
Andréa de Melo Cassinelli
}

\author{
Estruturação e Financiamento da Indústria \\ Cinematográfica Brasileira: a ambição de uma \\ trajetória autossustentável
}

Dissertação apresentada como requisito parcial para obtenção do grau de Mestre pelo Programa de Pós-Graduação em Engenharia de Produção PUC-Rio. Aprovada pela Comissão Examinadora abaixo assinada.

\author{
Profa. Fernanda Maria Pereira Raupp \\ Orientador \\ Departamento de Engenharia Industrial - PUC-Rio \\ Prof. Fabio de Silos Sá Earp \\ Instituto de Economia - UFRJ \\ Prof. Eduardo Figueiredo Bastian \\ Instituto de Economia - UFRJ
}

Prof. José Eugênio Leal

Coordenador Setorial do Centro Técnico Científico - PUC-Rio

Rio de Janeiro, 17 de outubro de 2012. 
Todos os direitos reservados. É proibida a reprodução total ou parcial do trabalho sem autorização da universidade, do autor e do orientador.

\section{Andréa de Melo Cassinelli}

Graduou-se em Ciências Econômicas na Universidade Federal do Rio de Janeiro e Université de Paris XII. Atualmente atua como analista financeira da área internacional do Banco BTG Pactual.

Ficha Catalográfica

Cassinelli, Andréa de Melo
Estruturação e financiamento da indústria
cinematográfica brasileira: a ambição de uma trajetória
autossustentável. / Andréa de Melo Cassinelli ; orientador:
Fernanda Maria Pereira Raupp - 2012.
104 f.: il. (color.); $30 \mathrm{~cm}$
Dissertação (mestrado) - Pontifícia Universidade
Católica do Rio de Janeiro, Departamento de Engenharia
Industrial, 2012.
Inclui bibliografia
1. Engenharia Industrial - Teses. 2. Indústria
cinematográfica. 3. Indústria audiovisual. 4. Políticas públicas.
5. Agência reguladora. 6. Mecanismos de financiamento. I.
Raupp, Fernanda Maria Pereira. II. Pontifícia Universidade
Católica do Rio de Janeiro. Departamento de Engenharia
Industrial. III. Título.

CDD: 658.5 
À minha mãe, in memorian. 


\section{Agradecimentos}

Ao meu pai, presença forte e onipresente em todas as etapas da minha vida. Não há forma de agradecimento suficiente para expressar o reconhecimento pela sua presença como um mastro de navio que não cede a nenhuma tempestade.

À minha mãe, que a despeito da ausência física anda de mãos dadas comigo e não me deixa esquecer das certezas que me fazem continuar a caminhar.

À minha família, dispersa entre as Minas Gerais e a França, pelas histórias incríveis e vontade de escrever episódios de vida inesquecíveis, como os que me foram contados desde a mais jovem infância.

Ao Pedro, pela companhia querida em todos os momentos da minha vida.

Aos meus irmãos Fernando, Léandro e Denis, pelo exemplo de força transmitido cada um à sua maneira, mas que me incitam a seguir em frente sempre.

À minha orientadora Fernanda Raupp, pela compreensão, suporte e confiança depositados em mim.

Ao meu professor e amigo, Fabio Sá Earp, pelo apoio a todo o momento e pelo profissionalismo e dedicação investidos neste tema de estudo que é a minha verdadeira inspiração: o Cinema. A ele, juntamente ao saudoso Fabio Erber, o agradecimento sincero pelo incentivo em continuar o tema iniciado no trabalho de conclusão do Bacharelado em Economia no Programa de Mestrado de Engenharia de Produção.

Aos amigos queridos que souberam neste como em outros momentos ser compreensivos face a ausência.

À Renata Gomes, Paula Faria, Michelle Engelhardt pelo companheirismo e amizades sinceras surgidas como presentes surpresa deste curso de Mestrado. 
Ao corpo docente do Departamento de Engenharia Industrial da PUC.

À CAPES, pelo suporte financeiro.

A todos que contribuíram para que esta etapa tão sonhada fosse cumprida. 


\section{Resumo}

Cassinelli, Andréa; Raupp, Fernanda Maria Pereira (orientador). Estruturação e Financiamento da Indústria Cinematográfica Brasileira: a ambição de uma trajetória autossustentável. Rio de Janeiro, 2012. 104 p. Dissertação de Mestrado - Departamento de Engenharia Industrial, Pontifícia Universidade Católica do Rio de Janeiro.

O desenvolvimento e consolidação da atividade cinematográfica enquanto indústria resultou de um processo longo e complexo de ações por parte de agentes tanto privados como governamentais do mundo todo, no intuito de encontrar um equilíbrio industrial, financeiro e social para esta atividade altamente onerosa e arriscada, porém estratégica para a maioria dos países. Com o advento das novas mídias no início do século XX e consequente aparecimento de uma nova indústria, mais complexa e abrangente - a indústria do audiovisual; foram levantadas fortes incertezas e gerados novos desafios para a atividade cinematográfica. No Brasil, o desenvolvimento da cadeia produtiva cinematográfica ainda é fortemente balizado por políticas públicas que fomentam a indústria e estas não tem sido suficientes para inserir o cinema nacional em uma trajetória de mercado. O objetivo da presente dissertação é analisar os processos de estruturação e consolidação da atividade cinematográfica, com respaldo na hegemônica cinematografia de Hollywood e transpor esta experiência para o caso brasileiro, tentando compreender as razões do insucesso em erguer uma proposta de desenvolvimento sustentável para a indústria cinematográfica nacional.

\section{Palavras-chave}

indústria cinematográfica; indústria audiovisual; políticas públicas; agência reguladora; mecanismos de financiamento 


\section{Abstract}

Cassinelli, Andréa; Raupp, Fernanda Maria Pereira (Advisor). Structuring and Financing of Brazilian Film Industry: the ambition of a selfsustaining path. Rio de Janeiro, 2012. 104 p. Master Science Dissertation Departamento de Engenharia Industrial, Pontifícia Universidade Católica do Rio de Janeiro.

The development and consolidation of cinema activity as an industry is the result of a long and complex number of actions from both private and governmental agents around the world, which aim to find an industrial, financial and social balance to this costly and risky activity. With the emergence of new media in the early twentieth century and the consequent emergence of a new, more complex and vast industry - the audiovisual industry; uncertainties have arisen and new challenges were generated in the movies activity. In Brazil, the development of the productive chain of filmmaking still remains dependent on strong public policies that promote the film industry and these policies have not been sufficient to integrate the film industry into a consistent market path. The purpose of this dissertation is to analyze the structuring and consolidation processes of the film activity, with the backing support of Hollywood filmmaking hegemony and transpose this experience for the Brazilian case in an attempt to understand the reasons for the failure in raising a proposal for sustainable development for national film industry.

\section{Keywords}

film industry; audiovisual industry; public policies; regulatory agency; financial mechanisms 


\section{Sumário}

1 INTRODUÇÃO 14

1.1 RELEVÂNCIA E JUSTIFICATIVA DO TEMA 18

$\begin{array}{llr}1.2 & \text { FormulaÇÃo do PROBLEMA } & 19\end{array}$

$\begin{array}{lll}1.3 & 19\end{array}$

1.3.1 Objetivo geral 19

1.3.2 Objetivos específicos 19

1.4 METOdOLOGIA APLICADA 20

1.5 ESTRUTURA DO TRABALHO 21

\section{A INDÚSTRIA CINEMATOGRÁFICA:}

\section{UMA APRESENTAÇÃO 23}

2.1 CARACTERÍSTICAS ECONÔMICAS E FINANCEIRAS DOS AGENTES CHAVE DA

CADEIA 23

2.1.1 O Produtor 24

2.1.2 O Distribuidor 26

2.1.3 O Exibidor 30

2.2 RECEITAS E REMUNERAÇÃo dos AGENTES DA CADEIA 35

2.2.1 O ciclo da Receita 36

2.3 DIFICULDADES DE PREVISÃO DOS RESULTADOS DAS OBRAS 39

2.3.1 Os interventores no plano de financiamento e os riscos incorridos 39

2.4 MODELOTEÓRICO 42

3 INSUSTENTABILIDADE DA INDÚSTRIA DO CINEMA?

O ADVENTO DA INDÚSTRIA AUDIOVISUAL E SUAS CONSEQUENCIAS

3.1 JUSTIFICATIVA HISTÓRICA DO SISTEMA DE AUXÍLIO À PRODUÇÃO CINEMATOGRÁFICA

3.1.1 Características estruturais da economia do cinema 46

3.2 EVOLUÇÃO HISTÓRICO-ESTRUTURAL DA INDÚSTRIA CINEMATOGRÁFICA: DA HEGEMONIA FRANCESA À HEGEMONIA NORTE-AMERICANA E À CONVERGÊNCIA AUDIOVISUAL

3.3 A APARIÇÃO DE NOVOS SUPORTES E A CONSTITUIÇÃO DA INDÚSTRIA AUDIOVISUAL

3.3.1 As novas janelas de exibição 


\section{CONSOLIDAÇÃO DA INDÚSTRIA CINEMATOGRÁFICA}

BRASILEIRA: INEFICÁCIA NO DESENVOLVIMENTO DE UMA TRAJETÓRIA SUSTENTÁVEL

4.1 AS PRIMEIRAS INICIATIVAS EM PROL DA INDÚSTRIA DO CINEMA BRASILEIRO

4.2 A ERA EMBRAFILME

$\begin{array}{lll}4.3 & \text { A RETOMADA } & 70\end{array}$

4.4 PROGRAMAS E MECANISMOS DE FOMENTO AO SETOR

CINEMATOGRÁFICO BRASILEIRO NA RETOMADA 72

4.4.1 ANCINE 72

4.4.2 Lei do Audiovisual 73

4.4.3 FUNCINES 75

4.4.4 Fundo Setorial do Audiovisual (FSA) 76

4.4.5 PROCULT 77

4.4.6 Cota de Tela 78

4.4.7 Lei da TV Paga 78

4.5 PANORAMA DOS ELOS DA CADEIA CINEMATOGRÁFICA BRASILEIRA NOS DIAS ATUAIS $\quad 81$

4.5.1 Posicionamento do elo da Produção 81

4.5.2 Posicionamento do elo da Distribuição 82

4.5.3 Posicionamento do elo da Exibição 85

4.6 ANÁLISE DOS RESULTADOS DOS PROGRAMAS E MECANISMOS DA RETOMADA $\quad 86$

5 CONCLUSÃO 91

6 REFERÊNCIAS BIBLIOGRÁFICAS 93

7 APÊNDICE 101 


\section{Lista de Tabelas}

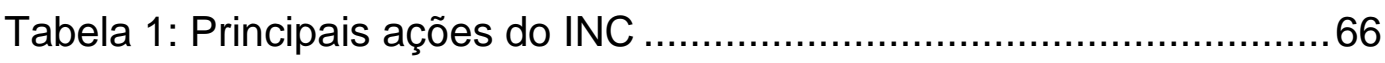

Tabela 2: Objetivos da ANCINE .................................................... 72

Tabela 3: Dotação orçamentária PROCULT (por subprograma)...............77

Tabela 4: Público e Renda de Filmes Nacionais por Ano (Todos gêneros) 80

Tabela 5: Dados gerais do mercado brasileiro ......................................101

Tabela 6: Dados básicos do mercado cinematográfico brasileiro ...........102

Tabela 7: Três principais bilheterias por ano $(1995$ - 2010) .................. 103 


\section{Lista de Figuras}

Figura 1 : Fluxograma de lançamento de uma obra cinematográfica.......29

Figura 2: Estrutura básica da ascensão das receitas ...............................38

Figura 3: Filme Exemplo: Demonstrativo de Resultados (em Reais) .......38

Figura 4: Cadeia da indústria do audiovisual........................................54

Figura 5: Conformação da indústria cinematográfica e convergência

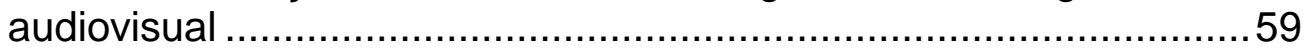

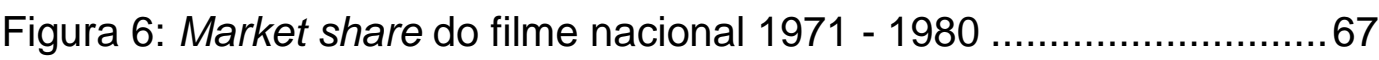

Figura 7: Mecanismo do artigo 1ำ da Lei do Audiovisual..........................73

Figura 8: Mecanismo do artigo $3^{\circ}$ da Lei do Audiovisual ..........................74

Figura 9: Evolução do número de salas no país 1971 - 2010 ................... 80

Figura 10: Evolução do market share do filme nacional 1995-2010 ........81

Figura 11: Evolução do público do filme nacional 1995-2010 …...............81

Figura 12: Market share das distribuidoras - Público e Renda ..................83

Figura 13: Market share das distribuidoras - Público e Renda filmes

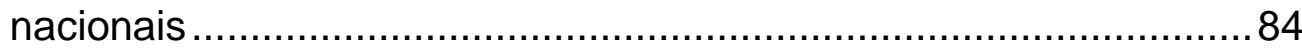

Figura 14: Dispersão das salas de exibição no país ................................ 85

Figura 15: Mapa de distribuição dos complexos multiplex no Brasil .........86

Figura 16: Conformação da indústria cinematográfica brasileira...............89 


\section{INTRODUÇÃO}

Desde o seu nascimento, o cinema distingue-se por duas características fundamentais. Por um lado, trata-se de uma forma de expressão cultural e artística excepcional, uma combinação mágica de luz e, posteriormente de som, projetada sobre uma tela em um ambiente que incita a plena utilização dos sentidos. Por outro lado, mais objetivo, o cinema constitui um dos melhores exemplos da aplicação de práticas industriais à produção e à distribuição de bens culturais.

O cinema implica, na esmagadora maioria das circunstâncias, na mobilização de vultosas somas de dinheiro além de exigir uma complexa divisão de tarefas necessárias à viabilização de uma obra e sua posterior difusão junto ao público. Devido a características intrínsecas à indústria do cinema, notadamente no tocante ao aspecto extremamente oneroso da atividade, a intervenção governamental se faz muitas vezes necessária de modo a garantir a sua manutenção e perenidade.

No Brasil, desde o início da década de 1990, a indústria cinematográfica vem assistindo, em maior ou menor grau de intensidade de acordo com o período, à transformação de todos os seus setores. Este processo tem resultado em uma notável melhoria na qualidade e profissionalismo no tocante à organização e mobilização de forças desta indústria, impactando desde a produção até a exibição.

O rompimento da antiga lógica dos mecanismos de financiamento, que até então se davam de forma direta, criou um novo impulso à produção, a partir da implementação de mecanismos de financiamento indiretos fundamentados sobre instrumentos de renúncia fiscal.

O elo da distribuição também assistiu a mudanças significativas. O abandono do modelo estatal e as novas associações com distribuidoras privadas, notadamente as estrangeiras, propiciaram um novo cenário de atuação para a distribuição, na medida em que as empresas deste ramo passaram a ser igualmente elegíveis aos mecanismos de incentivo coordenados pelo Governo. 
A abertura ao capital estrangeiro também propiciou uma profunda transformação do parque exibidor nacional, que após anos de atrofiamento e declínio da frequentação, assistiu à elevação do número de salas bem como à sua modernização.

Estas mudanças mercadológicas, conjugadas à transformação da forma de enxergar a cultura no país propiciaram a expansão e fortalecimento da atividade cinematográfica brasileira e da sua reafirmação enquanto indústria, estimulando a formação de mais profissionais para o setor e dando nova vida àqueles já consagrados.

O desenvolvimento e melhorias observados em todas as etapas de produção, desde maiores investimentos na realização dos roteiros até a formatação final das películas, permitiu aos filmes brasileiros atingir um grande aprimoramento técnico que, embora ainda muito aquém do nível de sofisticação de algumas cinematografias - notadamente a de Hollywood, foi capaz de colocar a produção nacional lado a lado com grandes produções internacionais e de inserir os filmes brasileiros nos principais circuitos do cinema.

Internamente, as produções nacionais passaram a contar com os dispositivos de dedução de impostos que possibilitaram às grandes empresas distribuidoras estrangeiras instaladas no Brasil, também conhecidas como majors, realizar investimentos em projetos cinematográficos brasileiros e receber em retorno o benefício fiscal.

Com as novas perspectivas de coprodução com empresas estrangeiras a partir da implementação dos benefícios fiscais indiretos, as produções brasileiras atingiram uma dimensão mercadológica bem mais robusta e ambiciosa, na medida em que passaram a contar com a infraestrutura destas consolidadas distribuidoras internacionais, tais como a Buena Vista, Columbia, Fox e Warner (ALMEIDA; BUTCHER, 2003).

O setor da exibição nacional por sua vez, foi o único dos três setores constituintes fundamentais da indústria cinematográfica que se desenvolveu sem o incentivo de instrumentos de benefício fiscal. A vultosa entrada de investimentos estrangeiros direcionada à introdução do novo conceito de exibição em voga nos anos 90 - o multiplex, engendrou um contexto de forte concorrência e 
impulsionou o setor exibidor brasileiro a reagir, realizando investimentos próprios e adequando-se à nova realidade da atividade de exibição. A união em um mesmo espaço de diversas salas de exibição, todas equipadas com o mais elevado padrão de conforto e com inovadora tecnologia de projeção e transmissão de som, constituiu o novo e inevitável conceito do setor de exibição e representou um marco na evolução da qualidade e na percepção do cinema enquanto forma de entretenimento.

$\mathrm{O}$ aparecimento da televisão na primeira metade do século $\mathrm{XX}$ colocou a indústria cinematográfica mundial em situação de forte desconforto, gerando profunda incerteza quanto ao seu futuro. Este marco, conjugado ao surgimento e evolução das novas mídias e instrumentos de entretenimento domésticos tais como vídeo e TV por assinatura só fizeram atrofiar a frequentação às salas de cinema e aprofundar o estado de decadência da indústria cinematográfica.

O surgimento e implementação do conceito do multiplex desempenhou nos Estados Unidos, Europa e posteriormente no Brasil um papel fundamental na reinvenção e reestruturação da atividade, possibilitando a renovação do hábito de frequentar o cinema como forma de lazer e abrindo um novo horizonte para a indústria.

Este constitui um esboço da situação da indústria cinematográfica brasileira nos últimos anos. Se o cinema iniciou a última década do século XX com poucas perspectivas de reestruturação e com um projeto indefinido de posicionamento e atuação na economia, ao final dos anos 90 conseguiu, com o incentivo e respaldo de políticas públicas de fomento, reerguer-se e dar nova dinâmica aos setores de produção, distribuição e exibição encontrados até então em estado de atrofia.

A despeito deste novo fôlego encontrado não se observou no país o desenvolvimento de um programa estratégico que aprimorasse o elo entre a indústria cinematográfica e os demais elos da indústria audiovisual, gerando sinergias entre a produção voltada para a exibição nas telas e a sua continuidade nos demais suportes de difusão. Como resultado desta inobservância e não adaptação à evolução da lógica audiovisual, o elo da distribuição e a comercialização das obras realizadas esbarram de forma permanente em 
dificuldades que só tendem a se agravar.

A presente dissertação se baseia na hipótese de que historicamente as políticas federais de fomento à indústria de cinema no Brasil não têm sido adequadas no intuito de melhorar a competitividade dos filmes brasileiros e inserir a atividade cinematográfica nacional em uma trajetória autossustentável. A questão da distribuição e comercialização dos filmes nacionais constitui um gargalo que atravessa décadas e, a despeito das diversas tentativas de implementação de programas de fomento à atividade cinematográfica nacional, observa-se que as iniciativas para regular a indústria do cinema e provocar a convergência entre esta e os demais elos da indústria do audiovisual nacional são insuficientes. Em não desenvolvendo o elo da distribuição e não provocando a convergência entre os elos da cadeia do audiovisual, as políticas federais não têm sido bem sucedidas na ambição de desenvolver uma indústria cinematográfica nacional forte e consolidada.

A presente dissertação pretende analisar o processo de consolidação da indústria cinematográfica no Brasil e avaliar se esta poderia lograr no objetivo de inserir-se em uma trajetória autossustentável.

Serão expostos os agentes atuantes na atividade e apresentadas as características inerentes ao setor que tornam compulsória a atuação de organismos externos à coordenação do mesmo. Será exposta a evolução vivenciada pela indústria do cinema desde seu estágio embrionário na Europa do século XIX até o aparecimento da indústria do audiovisual com o surgimento das novas janelas de difusão e avaliados os impactos provocados por estas na já frágil indústria cinematográfica. Em seguida será feita uma análise das políticas implementadas desde a primeira metade do século XX no Brasil no intuito de introduzir e desenvolver uma cinematografia nacional. Serão expostas as políticas que antecederam a criação da Embrafilme, a atuação da estatal até a sua extinção durante o Governo Collor percorrendo as tentativas de solidificação da atividade cinematográfica brasileira até os Governos Lula, atentando para a ausência de um programa que buscasse criar sinergias entre a indústria do cinema e as novas janelas de exibição. Por fim, serão analisados os principais mecanismos postos em prática no sentido de garantir o financiamento da atividade de produção nos dias atuais dada a nova conjuntura com a presença de diferentes suportes de difusão. 
Cabe ressaltar que a autossustentabilidade consiste em desafio muito difícil e ambicioso, tendo sido alcançado somente por duas indústrias de cinema: a norte-americana, comumente chamada de Hollywood, e a indiana, ou Bollywood. Por razões de metodologia de pesquisa, a presente dissertação adotará como métrica de comparação as indústrias norte-americana e francesa de cinema. Aquela primeira, devido ao processo de construção sinergético de sua indústria audiovisual que possibilitou a constituição de uma indústria cinematográfica forte e de presença global; esta segunda, devido ao seu pioneirismo na estruturação da indústria de cinema enquanto tal e às semelhanças no que toca a dependência de auxílios governamentais para a perenidade da atividade.

\subsection{Relevância e Justificativa do tema}

O cinema é conhecido pelos seus custos elevados e pelo aspecto imprevisível dos resultados do produto final, o filme. A despeito disso, a indústria cinematográfica, a qual está inserida dentro da economia criativa, possui um invejável potencial de geração de renda e emprego, além de ser um instrumento estratégico de registro, manutenção e divulgação da soberania cultural de um país tanto interna como externamente, de maneira que a compreensão e exploração desta indústria suscitam particular interesse a governos e grupos privados.

O conceito de economia criativa tem sua origem no termo indústrias criativas, resultado do desenvolvimento, na Austrália em 1994, do projeto Creative Nation. Este projeto defendia a importância do trabalho criativo, destacando sua contribuição para a economia do país, e o papel das tecnologias como aliadas da política cultural, dando margem à posterior inserção de setores tecnológicos no rol das indústrias criativas (COUTO, 2011).

Alguns anos mais tarde, no Reino Unido, o governo do primeiro ministro Tony Blair se deparando com uma competição econômica global crescente, estimulou a formação de uma força-tarefa multissetorial encarregada de analisar as contas nacionais do país, as tendências de mercado e as vantagens competitivas nacionais (FIRJAN, 2008).

O governo adotou uma iniciativa pioneira ao dar destaque ao que mais tarde se denominou indústrias ou economias criativas, buscando identificar a força geradora de empregos e renda dentro do terceiro setor. O dínamo encontrado nesta 
nova economia foram as atividades criativas, responsáveis por uma parcela cada vez mais importante da atividade econômica. A partir daí, foi estabelecida uma força tarefa no intuito de mapear esse setor identificando a sua participação no PIB, número de empregados, investimentos públicos e privados, entre outros dados econômicos.

Esse mapeamento estimulou inúmeros países e organizações a estudar o setor criativo e a buscar a captura da renda potencial das suas atividades. É importante notar, no entanto, que a definição do setor varia em cada estudo, e não há padronização nos dados divulgados, o que ainda dificulta a comparação internacional (FIRJAN, 2008).

O estudo das políticas de fomento e mecanismos de financiamento empregados a favor da indústria do cinema cujos orçamentos de projetos são, de modo geral, bastante elevados, é fundamental para se avaliar suas necessidades, possibilidades, deficiências e limitações e para viabilizar a elaboração de um projeto de estruturação que possa contribuir para o desenvolvimento e crescimento do país.

\subsection{Formulação do Problema}

A questão levantada inicialmente nesta dissertação foi:

É possível inserir a Indústria Cinematográfica brasileira em uma trajetória autossustentável?

A partir da análise da trajetória de estruturação da Indústria do Cinema no Brasil buscar-se-á julgar em que medida a constituição de um programa capaz de gerar sinergias entre os diferentes elos da indústria do audiovisual seria eficaz na proposta de inserir a cinematografia brasileira em uma trajetória autossustentável.

\subsection{Objetivos}

\subsubsection{Objetivo geral}

Avaliar a viabilidade da elaboração de uma proposta autossustentável para a indústria cinematográfica brasileira.

\subsubsection{Objetivos específicos}

- Analisar a trajetória de composição e afirmação da indústria 
cinematográfica brasileira, e identificar, a partir desta análise, os elementos mal sucedidos das políticas de fomento que se tornaram gargalos para a consolidação definitiva desta indústria.

- Identificar os elementos necessários à elaboração de um modelo de estruturação das políticas de fomento à indústria cinematográfica brasileira no intuito de fortalecer a atividade e inseri-la em uma trajetória de mercado sustentável.

\subsection{Metodologia aplicada}

Do ponto de vista da forma de abordagem, o estudo dos conceitos, do método, das práticas avaliadas e as análises sobre o potencial relacionamento entre Estado e indústria de cinema, a pesquisa é de caráter qualitativo. Os métodos qualitativos desempenham, segundo Godoy (1995), um importante papel no campo dos estudos organizacionais. Por não se apresentar como uma proposta de estruturação rígida de pesquisa, a abordagem qualitativa possibilita que os investigadores se valham com maior liberdade da imaginação e criatividade e proponham enfoques inovadores a seus objetos de pesquisa. A dinâmica de funcionamento das políticas de desenvolvimento da indústria do cinema é analisada e uma proposta de direcionamento das políticas de fomento elaborada, dentro do escopo metodológico do trabalho.

Do ponto de vista dos procedimentos técnicos, a presente dissertação fundamenta-se em pesquisa bibliográfica, pois procura em estudos, artigos publicados e nos sites institucionais das organizações regulatórias da indústria cinematográfica, documentos que demonstrem experiências e conclusões acerca do tema (GODOY, 1995).

Do ponto de vista de seus objetivos, essa pesquisa é exploratória, pois busca, através da análise de experiências bem e mal sucedidas e resultados estatísticos, mapear os pontos fortes e fracos da elaboração de políticas de fomento para a indústria cinematográfica nacional (STEBBINS, 2001). 


\subsection{Estrutura do trabalho}

O trabalho está organizado em quatro capítulos. O primeiro apresenta a Introdução do trabalho. $\mathrm{O}$ segundo faz uma exposição da indústria cinematográfica, através da apresentação dos principais aspectos econômicos, gerenciais e artísticos da atividade e dos três elos que compõem a cadeia, sejam o Produtor, o Distribuidor e o Exibidor. Ainda no capítulo 2 é feita uma análise de aspectos que são próprios ao setor cinematográfico, tais como a necessidade de importante mobilização de recursos e a sujeição, por parte dos agentes, a elevados riscos justificados pela incerteza no tocante aos resultados finais.

No capítulo 3 é feita uma análise histórica da evolução estrutural da indústria cinematográfica desde a composição da hegemonia francesa até a consolidação da hegemonia norte-americana no pós I Guerra e do aprofundamento do processo de convergência audiovisual iniciado com o surgimento da televisão no início do século XX. Finalmente, são expostos os impactos causados à indústria cinematográfica após a aparição e desenvolvimento das novas janelas de difusão e comentadas as necessidades de adaptação dos agentes da indústria em face de tais mudanças.

O capítulo 4 realiza uma exposição das políticas implementadas ao longo das últimas décadas no Brasil pelos diferentes Governos e sob diferentes regimes no intuito de constituir e solidificar a atividade cinematográfica nacional enquanto indústria geradora de empregos e agregadora de valores físicos e intangíveis à sociedade. São apresentados os principais mecanismos de fomento de caráter tanto privado como estatal adotados no Brasil na atualidade. A última seção do capítulo presta-se a fazer uma avaliação dos mecanismos apresentados, julgando em que medida foram capazes de atingir seu objetivo de promover o desenvolvimento do elo da produção de filmes bem como apresentando suas limitações no desenvolvimento dos demais elos da cadeia e notadamente em convergir as necessidades e rumos da atividade cinematográfica àqueles dos demais elos da indústria audiovisual.

O estudo geral da indústria é importante para entender algumas particularidades da atividade cinematográfica. A análise histórica é relevante para possibilitar o julgamento da viabilidade das medidas e políticas implementadas 
considerados o contexto histórico e a conjuntura político-econômica nos quais o país estava inserido bem como para identificar os erros no acompanhamento das novas dinâmicas da indústria audiovisual, notadamente após o aparecimento da TV. Por fim, é feita a apresentação da principal instituição reguladora da atividade cinematográfica brasileira, a ANCINE, e dos mecanismos de fomento empregados na conjuntura atual visando a possibilitar o desenvolvimento dos filmes tendo em vista a presença das novas janelas de difusão. 


\section{A INDÚSTRIA CINEMATOGRÁFICA: UMA APRESENTAÇÃO}

Este capítulo tem por objetivo fazer uma apresentação da indústria do Cinema. Para tanto, o presente está dividido em quatro seções, a saber: características econômicas e financeiras dos agentes chave da cadeia; receitas e remuneração dos agentes e as principais dificuldades enfrentadas pela indústria cinematográfica, notadamente no que diz respeito à forte incerteza, atrelada de forma inexorável à atividade. Na primeira, descreve-se o papel desempenhado pelos principais agentes da referida indústria. Em seguida, analisa-se a forma como se dão a geração e redistribuição de receitas, dadas as peculiaridades inerentes ao setor no que tange tais processos. Na seção 2.3 é debatida a questão das dificuldades dos agentes atuantes na atividade cinematográfica em prever o resultado de seus projetos e da indústria cinematográfica como um todo em estabelecer uma trajetória autossustentável de desenvolvimento. Por fim, é apresentado um modelo teórico estruturando as características da Indústria do Entretenimento e explicitando fatores que podem ser aproveitados, sempre que possível, no intuito de mitigar o risco de retorno das obras.

\subsection{Características econômicas e financeiras dos agentes chave da cadeia}

Esta seção visa a apresentar as entidades econômicas que compõem o núcleo da indústria cinematográfica. São elas: a Produção, a Distribuição e a Exibição. Tais atividades se articulam e influenciam mutuamente de maneiras variadas, porém sempre dentro de uma lógica de coerência, representada pelo desenvolvimento do produto final, o filme. O Produtor, o Distribuidor e o Exibidor agregam, cada um a seu turno, valor ao produto final. Cada elo apresenta estrutura e custos próprios, os quais determinam, ao final do processo, a rentabilidade e a remuneração de cada um, conforme será apresentado a seguir. 


\subsubsection{O Produtor}

O produtor desempenha ao mesmo tempo um papel artístico e de engenharia financeira (SANDOT, 2006, p.5). Responsável pela concepção do projeto, ele deve reunir e combinar o conjunto de elementos necessários à realização do filme, de modo a tornar viável a sua execução. Cabe ao produtor aliar recursos humanos, financeiros, comerciais, artísticos e técnicos, gerindo-os individual e coletivamente de forma a garantir a coerência necessária para concretizar cada uma das fases do projeto.

Se por um lado a viabilização e coordenação financeira representam o núcleo central da atividade realizada pelo produtor, não se pode, por outro, resumir o seu papel à figura de um mecenas. O produtor deve estar ciente do trabalho realizado em cada etapa e por cada uma das equipes envolvidas na produção do filme. Ele deve acompanhar a elaboração do roteiro, a escolha do elenco, os locais de gravação e seus aluguéis - quando for o caso; e outros aspectos técnicos e logísticos ligados ao processo, de modo que sua atuação, conforme já mencionado anteriormente, vincula-se, inexoravelmente, ao aspecto artístico da obra. Neste sentido a metáfora de um maestro de orquestra se adéqua à perfeição ao papel desempenhado pelo produtor na medida em que sua presença e atuação são determinantes na conjugação e harmonização corretas dos elementos constituintes da obra.

De modo geral, os produtores não mobilizam recursos próprios para a realização de seus projetos; o financiamento sendo feito, na maioria dos casos, com fundos captados de terceiros. Cabe ressaltar, no entanto, que a responsabilidade em caso de perdas financeiras é atribuída ao produtor ou à sociedade à qual este é vinculado. Observa-se, não raro, a constituição de coproduções, ou ainda, a vinculação a parceiros econômicos os quais recebem uma parte dos direitos sobre o filme em troca dos recursos disponibilizados para a realização do projeto.

Se considerarmos uma sociedade de produção, alguns custos não dependem do número de filmes produzidos. Os custos fixos, tais como material técnico, e outros custos gerais, são tanto mais diluídos quanto maior o número de filmes produzidos, devido à obtenção de economias de escala. Embora seja possível observar tais fenômenos - de diluição de custos e da geração de economias de escala; a elaboração de 
uma estrutura precisa de custos fixos e variáveis por filme constitui tarefa de difícil execução (SANDOT, 2006, p. 5). Este aspecto justifica-se pela enorme variabilidade dos custos observada em cada projeto.

Excetuados os casos de projetos pequenos e de baixo orçamento, a figura do produtor aparece raramente sozinha, sendo, na maioria das circunstâncias, acompanhada por uma equipe técnica e artística, cujo tamanho varia de acordo com o tipo de filme produzido e com a amplitude do orçamento do projeto. Conforme assinala Forest (2002),

"O número de técnicos pode variar fortemente de um tipo de filme a outro, indo de uma quinzena de pessoas para um curtametragem a quarenta pessoas para um longa-metragem clássico [...]. Este número pode se estender consideravelmente para filmes com orçamento mais importante, notadamente em casos de efeitos especiais, reconstituição de cenário (filmes de época), filmes de ação". (p. 77) ${ }^{1}$

Vale destacar, ainda, que de acordo com o país ou região onde atua, o produtor tem atribuições distintas tanto em grau como em forma. Conforme ressalva Farchy (2004), um produtor norte-americano trabalha, na maioria dos casos, para grandes estúdios, ou seja, grandes empresas de produção associadas a bancos e outros organismos financeiros de maior porte. Um produtor europeu ou latino-americano por outro lado, trabalha, na maior parte das circunstâncias, dentro de uma estrutura limitada tanto em termos de recursos técnicos quanto financeiros, devendo contar com recursos de organismos menores que se acumulam ou com ajudas do Governo (FARCHY, 2004, p. 89).

O cinema constitui uma arte altamente onerosa e a sua rentabilização, dados os aspectos imprevisíveis dos resultados dos filmes, é em grande medida aleatória. $\mathrm{Na}$ etapa inicial do projeto, ou seja, no momento em que os aspectos primários do filme são debatidos, este risco é máximo, devido à incerteza no que toca a sua concretização. Esta depende, em grande parte, da capacidade do produtor em atrair capital o suficiente para

\footnotetext{
${ }^{1}$ Traduzido do original pela autora.
} 
o financiamento do filme. Uma vez os recursos disponibilizados, o produtor fica com a incumbência de gerí-los e de conjugá-los ao conjunto de recursos humanos e artísticos acessíveis, de maneira a finalizar a obra (FOREST, 2002).

O produtor deve atingir o elo da distribuição com um pacote composto pela obra cinematográfica. Assumindo que da elaboração deste pacote resultam despesas de aquisição de direitos sobre uma obra literária e do desenvolvimento do projeto, a primeira questão que o produtor irá tratar será a barganha junto ao distribuidor do pagamento dos custos incorridos desde o início do projeto. Tais custos abarcam não somente custos de aquisição de direitos autorais, confecção do roteiro, mas também gastos de pré-produção tais como locação de estúdios, propriedades etc, adiantamento de taxas legais dentre outros conforme mencionado anteriormente.

Conforme apontam Baumgarten et al. (2004), como raramente o contrato entre produtor e distribuidor comtempla o desenvolvimento de propriedade intelectual ou roteiro, a maioria dos distribuidores remunera o produtor baseado unicamente no sucesso do desenvolvimento do projeto. Em outras palavras, somente se o filme é concluído, o produtor receberá a integralidade do pagamento acordado junto ao distribuidor. Se o projeto não for concluído o produtor recebe um pagamento limitado, ou não recebe nada, dependendo dos serviços realizados ao longo do período de desenvolvimento do projeto ou dos termos firmados contratualmente entre as partes. Além disso, é relevante mencionar que não raro, os crontatos são sujeitados a modificações e adendos ao longo da vida da obra. (BAUMGARTEN et al., 2004, p. 76)

\subsubsection{O Distribuidor}

Situado entre o produtor e o exibidor, o distribuidor tem a função de valorar comercialmente o produto final fornecido pelo produtor. O distribuidor compra dos produtores os direitos sobre cada um dos títulos produzidos para, em seguida, comercializá-los em um ou mais suportes de difusão. Destes últimos destacam-se as salas de cinema, vídeo e canais de televisão.

Uma vez a obra cinematográfica concluída, o distribuidor tem a incumbência de dar sequência à cadeia produtiva. A decisão referente ao número de salas a serem mobilizadas para a difusão da obra bem como sua locação é fundamentada na estimativa 
ex ante do distribuidor acerca da demanda pelo filme. A dimensão de demanda projetada para o lançamento inicial determina o número de cópias de películas necessárias para a distribuição nas salas de exibição. O número de espectadores habilitados a assistir o filme por sua vez, limita-se ao número de assentos disponíveis por sessão nas salas de exibição mobilizadas para o lançamento da obra.

A maioria dos distribuidores se utiliza de um processo de leilão para realizar o licenciamento dos filmes às salas de exibição. Estas últimas indicam seu desejo em negociar a licença de exibição e a seleção de salas é feita obedecendo aos planos de lançamento elaborados pelo distribuidor. Quando o desempenho de uma obra supera as expectativas e os assentos das salas são amplamente preenchidos, observa-se a geração de economias de escala que se tornam tanto maiores a cada semana de exibição em que os assentos são preenchidos. Neste sentido, a expansão do período de exibição consiste em fonte direta de ampliação de receitas do filme na medida em que as despesas realizadas durante a produção, a tiragem de cópias das películas e propaganda constituem custos fixos que são diluídos ao longo do período de exibição do filme. (DE VANY, 2004)

A adaptação à demanda pelos filmes consiste em um processo dinâmico. A oferta de assentos para uma obra bem-sucedida é ajustada através da ampliação do número de semanas na agenda de exibição do filme nas salas. Os distribuidores utilizam a informação adquirida dos relatórios de desempenho dos filmes para adaptar oferta à demanda. Ao observar uma trajetória elevada de audiência de determinada obra outros exibidores podem desenvolver interesse em inserí-la em sua carteira de exibição e dependendo do desempenho da mesma o distribuidor pode ver-se obrigado a produzir mais cópias para alinhar a oferta.

Neste sentido, De Vany (2004) aponta para o fato da indústria cinematográfica possuir um aspecto peculiar em sua lógica distributiva: em decorrência da flexibilidade em adaptar a oferta de assentos à demanda, a indústria cinematográfica consegue capturar os chamados "efeitos manada" (bandwagon effects), iniciados com comentários tanto oficiais como extra-oficiais ("boca a boca") acerca de determinada obra em cartaz. 
Conforme assinalado por Forest (2002), o distribuidor se situa no cerne da particularidade econômica do cinema, que, contrariamente à quase totalidade dos demais setores da economia, não vende seus produtos (de montante à jusante e do produtor ao varejista), mas os aluga aos exibidores. Cabe, portanto, ao distribuidor, a gestão do "ciclo das receitas" 2 , através da transmissão do produto final entre os elos da indústria que possibilita a geração das receitas e, por fim, a sua repartição entre os diferentes agentes envolvidos na cadeia produtiva.

Grosso modo, pode-se afirmar que o papel chave desempenhado pelo distribuidor consiste na otimização da difusão dos títulos cujos direitos são por ele adquiridos. O posicionamento do distribuidor é crucial para o filme tanto no que tange a recepção deste pelo seu público potencial como para a sua rentabilização.

A despeito desta função central, as tarefas desempenhadas pelo distribuidor são de natureza diversa. Ele deve, conforme mencionado anteriormente, julgar o potencial econômico e a expectativa de demanda de cada filme, estipular a data de seu lançamento, o número de salas que devem ser mobilizadas e, por conseguinte, o número de cópias das películas a serem feitas (FOREST, 2002, p.69). Cabe, portanto ao distribuidor a gestão dos custos de comercialização e da estratégia de marketing do filme, desde a sua promoção até a coordenação do material publicitário como panfletos, propagandas e cartazes, também conhecidos como P\&A (printing \& advertisement) ${ }^{3}$.

Uma vez adquiridos os direitos de difusão junto ao produtor e estipulada a amplitude de difusão desejada (número de cópias, salas etc), o distribuidor fica encarregado de fabricar as cópias da obra em laboratórios especializados e de efetuar a sua locação e distribuição física aos exibidores, a quem ficam cedidos temporariamente os direitos de difusão. O distribuidor adéqua o número de cópias e a publicidade em

\footnotetext{
${ }^{2}$ Em “L'argent du Cinéma: Introduction à l'économie du septième art” Editions Belin, Paris, 2002, Forest utiliza o conceito ao qual denomina "Remontée des Recettes", ou "Ascensão das Receitas". Consiste no mecanismo financeiro que se inicia com a coleta da receita oriunda das bilheterias (Exibidor), "sobe" ao Distribuidor - responsável pelo aluguel do filme, que, por sua vez, transmite uma parte desta mesma receita ao Produtor.

${ }^{3}$ As cópias físicas das obras custam cerca de US\$ 2.000 por impressão. Cada cinema precisa de pelo menos uma cópia e possivelmente mais, dependendo de quantas salas estão exibindo o filme. A parte do orçamento referente à publicidade constitui montante significativo. A maior parte deste orçamento é gasta na TV, porém rádio, jornais, revistas, internet e trailers também são muito importantes. A média do orçamento de $P \& A$ para um lançamento de grande estúdio é de 30 milhões dólares (MPAA).
} 
função do potencial do filme e de acordos previamente estabelecidos junto ao produtor (BONNEL, 2006).

A Figura 1 apresenta o fluxo completo do lançamento de uma obra cinematográfica.

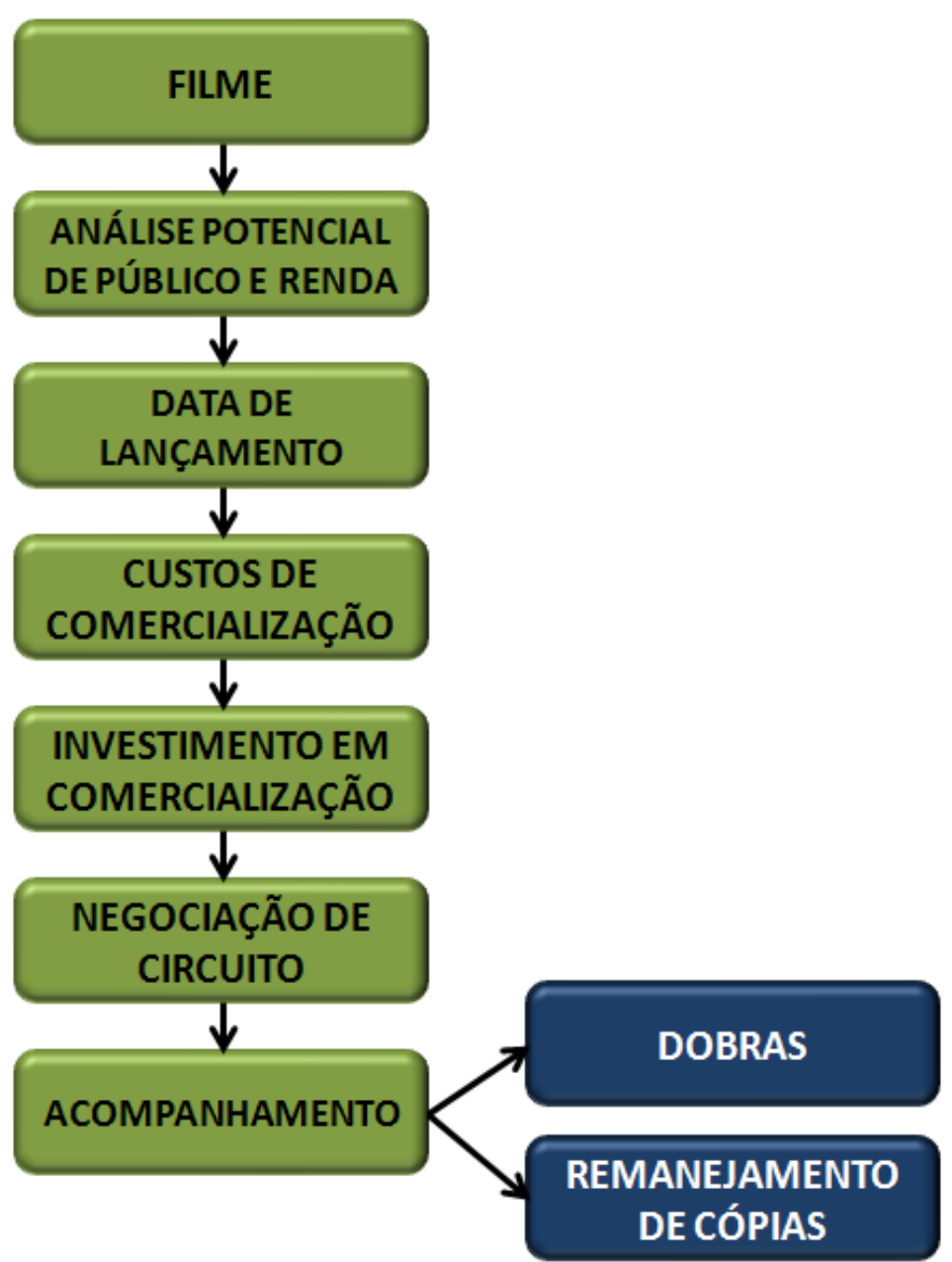

Figura 1 : Fluxograma de lançamento de uma obra cinematográfica

Fonte: Elaboração própria a partir de BRITZ, BRAGA, DE LUCA, (2010)

Mesmo necessitando de pouco material técnico e não possuindo restrições particulares impostas pelos exibidores, o distribuidor deve avançar recursos para os gastos de edição (custos de publicidade e de tiragem de cópias) de maneira que o seu risco financeiro é consideravelmente elevado. 
Os custos variáveis do distribuidor são constituídos por despesas técnicas ligadas à tiragem de cópias e ao processo de estocagem das mesmas (custos de laboratório). As despesas de laboratório representam uma média significativa dos custos totais de edição, sendo tanto mais diluídas quanto maior o número de cópias efetuado.

Os custos fixos, por sua vez, são compostos pela concepção e fabricação dos trailers, compra ou aluguel de espaços publicitários e custos de promoção, dentro dos quais podemos destacar os gastos com a imprensa (pré-estreias, festivais, viagens etc.) e a elaboração de material publicitário, como já mencionado anteriormente.

Sandot (2006) releva o fato de que atualmente, os distribuidores devem fazer face à forte inflação observada nas despesas de edição. De fato, a oferta abundante de filmes intensifica a concorrência publicitária, forçando os filmes a permanecer cada vez menos tempo em cartaz, o que dificulta a sua rentabilização.

No que tange à posição pouco confortável dos distribuidores, Bonnel (2006) aponta:

"A oferta massiva [de filmes] aumenta a concentração dos resultados e agrava a instabilidade do mercado. O número de insucessos sendo muito superior ao de sucessos [...] enfraquece a manutenção dos filmes em cartaz, os quais são guiados pela dialética assassina: triunfo rápido ou fracasso imediato". (p.113) ${ }^{4}$

A primeira semana de exibição é crucial e o produtor tem todo o interesse que o seu distribuidor aumente o número de cópias das películas. Em contrapartida, ao aumentar muito o número de cópias, o distribuidor eleva fortemente o seu risco, além de provavelmente diminuir a rentabilidade de cada cópia.

\subsubsection{O Exibidor}

A Exibição constitui o estado último da cadeia cinematográfica, estabelecendo o contato direto com os consumidores finais através da oferta da representação cinematográfica propriamente dita. Os exibidores atraem e recebem os espectadores,

\footnotetext{
${ }^{4}$ Traduzido do original pela autora.
} 
projetam o filme e recebem, por seus serviços, uma receita. Na maioria dos países desenvolvidos, os ingressos dos filmes são numerados, devendo os exibidores efetuar a contabilidade de cada filme, sessão por sessão, semana por semana, a fim de remunerar os distribuidores prorata das entradas e das receitas registradas.

O exibidor gere um estabelecimento no qual ele executa a difusão das obras cinematográficas ao público, além de organizar outras atividades vinculadas à difusão, tais como locação de espaços publicitários e gestão de serviços de alimentação (pipoca, bonbonière etc.).

O exibidor aluga dos distribuidores cópias dos filmes por um período prédeterminado - de modo geral, por algumas semanas; e os projeta nas salas. Ele negocia, além disso, a programação dos locais de estreia junto ao distribuidor, ou delega tal atividade a um grupo gestor competente.

A Exibição caracteriza-se pelos seus custos fixos notavelmente elevados. Estes se constituem de aluguéis, despesas financeiras eventuais referentes à aquisição de locais, manutenção das salas e do material, despesas com pessoal e despesas gerais. Destas, devem ser destacadas as despesas com energia elétrica, notadamente aquelas vinculadas à calefação e refrigeração de ar, as quais devem ser adaptadas às condições climáticas e à densidade de espectadores presentes nas salas. Tais despesas são bastante representativas. $\mathrm{O}$ exibidor é o agente da cadeia que suporta, em proporção, os maiores custos fixos, e, por conseguinte, é o mais afetado pelas variações nas bilheterias.

De modo geral, os exibidores dispõem de ativos de valor tais como imóveis, que lhes conferem um pouco de segurança em caso de crises de frequência às salas - à diferença dos distribuidores, cujo principal ativo consiste nos direitos sobre a comercialização das obras.

Através da observância do desempenho das obras cinematográficas após o lançamento inicial, decisões de expandir ou encurtar contratos de exibição podem vir a ser tomadas, desde que respeitadas as cláusulas contratuais estipuladas previamente entre distribuidor e exibidor a cada obra negociada e/ou feitas as devidas modificações. O exibidor se vale dos dados de desempenho do filme em cartaz em sua sala de exibição para decidir quão longa será sua permanência. 
Um contrato de exibição usualmente estabelece um período mínimo de semanas para permanência de um filme em cartaz. A maioria dos contratos estipula uma cláusula que requer que a sala de exibição mantenha um filme em cartaz na eventualidade da renda proveniente da exibição do mesmo ultrapassar determinado montante de bilheteria, contratualmente acordado.

Os exibidores remuneram o distribuidor do filme através de aluguéis semanais em troca do direito de exibir a obra. O aluguel é normalmente constituído por um percentual da receita gerada pelo exibidor. $\mathrm{O}$ arranjo de remuneração costuma estipular percentuais decrescentes da receita proveniente da exibição, que variam em função da semana de comercialização do filme. Um padrão comum de remuneração obedece a uma variação dos seguintes percentuais: 70, 70, 60, 60 para a primeira, segunda, terceira e quarta semanas de exibição, respectivamente. Semanas adicionais de exibição costumam ter a taxa de aluguel do filme reduzida, porém, ao ultrapassar o montante de receita semanal negociado contratualmente junto ao distribuidor o exibidor pode se ver obrigado a retornar até $90 \%$ do valor obtido que exceda tal montante (DE VANY, 2004). A vantagem deste tipo de acordo para o distribuidor consiste na possibilidade de auferir um grande retorno financeiro caso o filme possua potencial elevado de geração de receita. Por outro lado, se nestas semanas suplementares a obra apresenta um desempenho ruim, o distribuidor pode ter um ganho inexpressivo ou mesmo perder dinheiro.

Embora já previamente mencionado, os acordos referentes ao elo da exibição contém alguns aspectos que merecem destaque. Os acordos de exibição são comumente compostos de cláusulas padrão, válidas para a maioria das obras postas em cartaz. Uma vez devidamente estipulado e oficializado, o acordo de exibição deve especificar o nome do estabelecimento de exibição, detalhes da Pessoa Jurídica responsável, nome da obra e a duração do prazo de exibição.

A determinação do prazo de exibição de uma obra cinematográfica pode seguir alguns critérios distintos. Distribuidor e Exibidor podem acordar a determinação deste prazo baseados na divisão da receita bruta de bilheteria, na divisão da receita de bilheteria após o exibidor ter recuperado as despesas operacionais do estabelecimento 
no início do período de exibição ou ainda mediante o pagamento de uma soma préestabelecida por todo o período de exibição (BAUMGARTEN et al., 2004).

Quando é feita a opção pela divisão simples das receitas de bilheteria pode haver determinação prévia de pagamento mínimo garantido de aluguel do exibidor ao distribuidor, como medida de mitigar os riscos do distribuidor de uma frequência inesperadamente baixa às salas. Quando da opção pela divisão da receita de bilheteria após a recuperação das despesas operacionais por parte do exibidor o que se observa é o seguinte: uma vez acordado um montante referente aos custos operacionais do estabelecimento, o distribuidor geralmente mantém tal valor para os demais filmes a serem postos em cartaz naquele cinema a menos que haja novas exigências de elevação de tal montante por parte do exibidor decorrente de aumentos declarados de suas despesas operacionais. Como comumente na rubrica "despesas operacionais do estabelecimento de exibição" (sala de cinema) encaminhada pelo exibidor já está embutida uma margem de lucro observa-se, não raro, a exigência de realização de auditoria contábil por parte do distribuidor (BAUMGARTEN et al., 2004, p. 230).

Outra forma menos comum de repasse de receitas consiste no acordo de Escala Móvel. Diferentemente do repasse baseado em percentuais fixos acordados sobre a bilheteria, o repasse escalonado permite ao distribuidor auferir percentuais maiores dos resultados da bilheteria de acordo com o desempenho destes últimos. Em outros termos, quanto maior a receita de bilheteria, maior a parcela repassada ao distribuidor. Um contrato em Escala Móvel padrão consiste no "25-50". Através deste tipo de contrato fica estipulado que o distribuidor recebe um percentual mínimo de $25 \%$ da receita com bilheteria e que tal percentual pode atingir o patamar máximo de $50 \%$. O percentual de $25 \%$ corresponde supostamente às despesas operacionais do estabelecimento cinematográfico. Assim sendo, se em uma dada semana a receita bruta de bilheteria não excede tal patamar, o exibidor mantém consigo toda a receita auferida. Uma vez este patamar atingido, o exibidor mantém $75 \%$ da receita ou menos e o distribuidor aufere $25 \%$ ou mais, conforme a performance da receita de bilheteria do filme.

Um aspecto fundamental a ser salientado e que toca diretamente os exibidores diz respeito à queda da frequência das salas de cinema a partir do final dos anos 
cinquenta em decorrência da entrada massiva dos aparelhos televisores nos lares (FARCHY, 2004). A baixa na frequência "dizimou a exibição, vítima da rigidez dos seus equipamentos e dos seus custos" (BONNEL, 2006, p.129). Nos anos 1960-70, como resposta à queda de público nas salas de cinema, assistiu-se à construção de grandes complexos oficialmente denominados multiplex, cuja evolução permanece dinâmica até os dias de hoje.

Após aproximadamente uma década de fuga dos espectadores e de um movimento massivo de falências e fechamento de salas, o setor da exibição começou a reagir. Conforme salienta Bonnel, "os exibidores descobriam as vantagens do supermercado: o máximo de produtos em um mínimo de volume para rentabilizar cada metro quadrado construído" (BONNEL, 2006, p. 131). As novas salas multiplex melhoram o rendimento por poltrona instalada, estimulam a frequência através da intensificação da oferta de filmes e permitem uma flexibilização da programação. Tal aspecto facilita, ainda, adaptações no que tange à capacidade de recepção do público face ao potencial comercial de cada filme, semana por semana, diluindo, portanto, os riscos de perdas gerados por previsões equivocadas da bilheteria por filme.

Um aspecto relevante decorrente da introdução dos conjuntos multiplex é, em certo grau, a "democratização" forçada da seleção dos filmes a serem postos em cartaz. A quantidade elevada de salas gera consequentemente uma demanda maior por filmes. Esta ampliação da demanda resulta em estímulo a maior produção de títulos bem como à sua diversificação, de modo a atender públicos de gostos e faixa etária diversos. Outro fator importante e estratégico aproveitado pelo conceito multiplex consiste no "Second Best" (opção pelo segundo melhor). Em não havendo disponibilidade de ingressos para o filme desejado, a disponibilidade de outros filmes abarcados na estrutura do multiplex, pode, muitas vezes, reter o consumidor e garantir a captação de renda (ALMEIDA; BUTCHER, 2003).

De acordo com Farchy (2004), o público mais jovem, mais citadino, mais culto, tornou-se, de fato, mais exigente após a aparição da televisão. Os complexos apresentam, neste sentido, a vantagem de poder abranger um público mais vasto e diverso, oferecendo uma gama diversificada de produtos. 
Este tipo de construção se multiplicou nos anos 70 , provocando um forte movimento de concentração da atividade de exibição. Os conglomerados cinematográficos, situados em pontos específicos das grandes cidades, notadamente em centros comerciais, desenvolveram-se de forma acelerada, sucedendo os cada vez mais raros cinemas de rua (BONNEL, 2006).

\subsection{Receitas e Remuneração dos agentes da cadeia}

A seção em questão trata com maiores detalhes do processo de geração de receitas dentro da atividade cinematográfica e da forma como estas são repartidas entre os diferentes agentes da indústria. Tal análise se justifica devido à particularidade de tais processos dentro da cadeia cinematográfica. As receitas dos filmes são redistribuídas de forma ascendente e progressiva aos diferentes agentes atuantes na atividade. Estes dividem não os lucros oriundos dos filmes, mas suas receitas, que sobem de jusante à montante.

Cada um dos agentes da cadeia obtém uma rentabilidade própria, que é função de sua estrutura de custos e do ambiente de concorrência dentro do qual eles operam. A divisão do montante final é negociada entre os agentes e evolui de acordo com relações de influência de cada parte. O distribuidor parece ser nos dias atuais o elo mais frágil da cadeia. Conforme destacado por Bonnel (2006),

"a distribuição foi uma das grandes vítimas da evolução da freqüência [às salas de cinema]. Sua posição de intermediário the custou caro em uma situação de crise onde seus parceiros situados à montante [produtor] e à jusante [exibidor] buscaram comprimir seus gastos gerais e, portanto, a minimizar o papel desempenhado pela distribuição" (p.102) ${ }^{5}$

O produtor, último a recuperar sua parte e primeiro implicado no projeto, deve ser cauteloso na sua gestão financeira antes de beneficiar-se das eventuais receitas crescentes oriundas dos novos suportes de difusão, posto que estas são incertas.

\footnotetext{
${ }^{5}$ Traduzido do original pela autora.
} 
A seguir, será apresentado o tronco comum da estrutura de remuneração dos agentes. Embora já mencionado na introdução da presente seção, vale ressaltar que tal estrutura representa apenas um esboço daquilo que é observado na prática. Os produtos gerados pela indústria cinematográfica caracterizam-se pela sua unicidade tanto no tocante ao resultado final do projeto - o que pode parecer um pouco evidente; como também de todos os aspectos econômicos a eles vinculados.

Assim, a remuneração dos agentes deve, na prática, ser analisada individual e isoladamente. Cada projeto constitui um caso particular e a remuneração dos agentes dependerá fortemente da força de barganha de cada um, bem como do potencial mercadológico da obra em questão.

\subsubsection{O ciclo da Receita}

A receita ${ }^{6}$ oriunda da bilheteria sobe aos diferentes elos da cadeia cinematográfica partindo de uma posição situada à jusante da atividade.

O exibidor coleta a receita oriunda da venda de ingressos das salas de exibição, transfere uma parcela da mesma ao distribuidor e conserva o restante. Os contratos de locação dos filmes às salas preveem uma taxa de locação que é aplicada às diferentes semanas de exibição, conforme mencionado na seção 2.1.3 do presente capítulo.

O distribuidor é remunerado pelo exibidor através da receita de bilheteria calculada sobre a base da declaração de receitas realizada pelo exibidor.

O exibidor conserva um percentual contratualmente acordado aproximadamente, 50\% - da receita oriunda da venda de ingressos (receita bilheteria), com a qual ele deve cobrir seus custos fixos e, preferencialmente, ser capaz de extrair uma margem de lucro, repassando o restante ao distribuidor.

${ }^{6}$ Por conta da impossibilidade em caracterizar de maneira simplificada a composição dos diferentes tipos de receita (bruta, líquida...), o presente trabalho adotará o termo receita, sem maiores especificações. 
O distribuidor, por sua vez, conserva as receitas captadas até que tenham sido cobertos os gastos com edição, por ele avançados. Uma vez os gastos com edição reembolsados, o distribuidor retira uma porcentagem de comissão sobre as receitas que o exibidor continua lhe repassando como contrapartida ao seu trabalho de distribuição.

Se o distribuidor não assumiu nenhum risco na etapa da produção, a comissão será pequena (da ordem de 10\%). No entanto, se o distribuidor fez adiantamentos ao produtor, ele terá, em contrapartida, direitos mais elevados sobre a difusão dos filmes nas salas de exibição (20 a 40\%) (FOREST, 2002, p. 119). Tal porcentagem, definida contratualmente, se situa, de modo geral, entre 25 e $35 \%$ da receita do distribuidor e depende do tipo de contrato firmado junto ao produtor.

Após ter sido remunerado, o distribuidor repassa ao produtor a receita que lhe cabe. Esta parte diz respeito a todos os interventores financeiros no início da cadeia, durante o processo de elaboração do filme. O produtor se situa, estruturalmente, em uma posição de risco, posto que é o primeiro implicado financeiramente no projeto e o último remunerado pela lógica da "ascensão das receitas".

A Figura 2 apresenta o mecanismo de repartição das receitas através dos elos da cadeia produtiva. 
Mecanismo da repartição das receitas

( $\mathrm{N}^{\circ}$ entradas filme) $\mathrm{X}$ (Preço da entrada) $=\underline{\text { Receita bruta quichê }}$
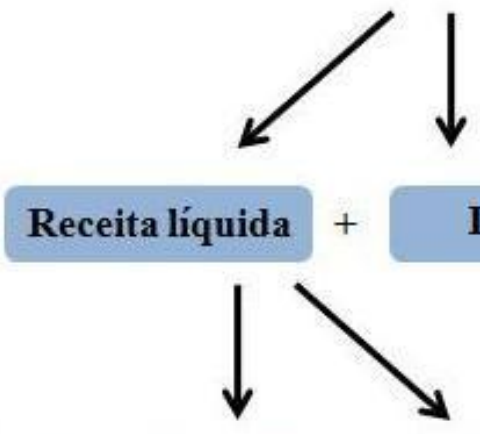

Impostos

\section{Receita Distribuidor + Receita Exibidor}

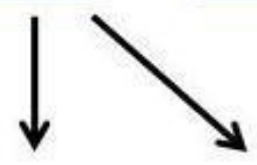

\section{Comissão de distribuição + Parte Produtor}

Figura 2: Estrutura básica da ascensão das receitas

Fonte: Elaboração própria a partir de Forest (2002)

A Figura 3 apresenta um exemplo de Demonstrativo de Resultados de um filme.

\begin{tabular}{|c|c|c|}
\hline \multicolumn{3}{|l|}{$\begin{array}{c}\text { Demonstrativo de Resultados - Lucros e Perdas } \\
\text { de Out/2011 a Mar/2012 } \\
\text { Expresso em Reais }\end{array}$} \\
\hline Descrição & & Acumulado \\
\hline (Público 1.238.125 × PMI) & $\begin{array}{c}\text { PMI } \\
12,87\end{array}$ & $15.934 .668,75$ \\
\hline (-) Impostos sobre Faturamento Bruto & & $796.733,44$ \\
\hline (-) Participação dos Exibidores & & $7.170 .600,94$ \\
\hline Receita Bruta de Comercialização & & $7.967 .334,38$ \\
\hline (-) Impostos sobre Faturamento & & $1.354 .446,84$ \\
\hline Receita Liquida de Comercialização & & $6.612 .887,53$ \\
\hline (-) Comissāo de Distribuição & $30,0 \%$ & $1.983 .866,26$ \\
\hline Receita Bruta dos Produtores & & $4.629 .021,27$ \\
\hline (-) Marketing & & $1.355 .937,22$ \\
\hline (-) Copiagem do Drama e Trailler & & $396.754,16$ \\
\hline (-) Outras Despesas & & $122,462,04$ \\
\hline Total de Gastos de Distribuição & & $1.875 .153,42$ \\
\hline Receita Líquida dos Produtores (Equity) & & $2.753 .867,85$ \\
\hline
\end{tabular}

Figura 3: Filme Exemplo: Demonstrativo de Resultados (em Reais)

Fonte: BRITZ, BRAGA, DE LUCA, (2010) 
Assim, os registros contábeis provenientes das vendas de bilhetes para as salas de exibição que projetam os filmes constituem, como já mencionado anteriormente, a receita de bilheteria. Desta, uma parte constitui a remuneração do exibidor e a outra, denominada "Comissão de distribuição", é conservada pelo distribuidor para a remuneração de seus serviços prestados. A parte restante constitui a parcela do produtor.

O exibidor confere ao distribuidor uma fração da receita estipulada no contrato de locação que, por sua vez a redistribui entre ele mesmo e os demais interventores da cadeia produtiva. Ao realizar tais ações o distribuidor preenche sua posição crucial no ciclo das receitas (FOREST, 2002, p. 120). O distribuidor reembolsa, quando o caso, a parte por ele adiantada ao produtor para a realização do filme, e as suas despesas com edição de cópias e publicidade. Ele recupera uma porcentagem da receita que varia entre 25 e $50 \%$ da receita oriunda da venda nas bilheterias das salas de exibição.

2.3 Dificuldades de previsão dos resultados das obras

O cinema não se financia como uma atividade industrial qualquer. Um empresário do ramo, ou, mais especificamente, um produtor, assume o risco de fabricar um produto (o filme) e em seguida realiza a amortização de seus empréstimos obtendo, eventualmente, uma margem de lucro através da comercialização do bem final nas salas de exibição, televisão, exportação etc. A presente seção se propõe a apresentar, através de um curto debate acerca da imprevisibilidade e dinâmica de comportamento frequentemente caótica; do resultado de uma obra cinematográfica, alguns aspectos que caracterizam a indústria do cinema como inexoravelmente arriscada e sem garantias efetivas de retorno.

\subsubsection{Os interventores no plano de financiamento e os riscos incorridos}

Quão arriscada é a indústria cinematográfica? A famosa citação do roteirista norte-americano William Goldman de que na indústria do entretenimento "ninguém sabe de nada" ("Nobody knows anything") é realmente fundamentada?

O produtor, conforme já explicitado anteriormente, é o encarregado pela captura dos meios financeiros necessários à fabricação do filme. Para tanto, ele busca, à proporção de suas necessidades de recursos, diferentes interventores de modo a 
estruturar seu plano de financiamento. Além disso, cabe lembrar a constituição de coproduções, prática bastante comum no meio, que alivia as necessidades de captação de recursos para todas as partes envolvidas.

O risco financeiro do produtor é função da estrutura de captação e de despesas que ele estabelece. Assim, quanto mais ele aumenta a parte das antecipações das receitas, mais ele minimiza seus riscos, mas ao fazê-lo, ele diminui igualmente as suas perspectivas de rentabilidade (GOLDMAN, 1989).

O produtor antecipa com frequência considerável as receitas potenciais de um ou mais suportes de exibição de modo a financiar seu projeto. Ele pode antecipar as receitas futuras das salas de exibição de forma a garantir uma renda mínima ao distribuidor; pode igualmente antecipar uma receita mínima aos editores de vídeo, sustentado pelas perspectivas do crescente mercado de audiovisual (DVDs etc.) e ainda antecipar as vendas de direito de distribuição televisuais. Estas últimas constituem antecipações de receitas significativas na elaboração dos planos de financiamento.

Inúmeros questionamentos derivam desde essa primeira etapa de constituição de uma obra cinematográfica. Quais são as fontes de risco do negócio cinematográfico? Porque é tão difícil lidar com este risco? É possível medir quão arriscada é a atividade cinematográfica? Porque o retorno é frequentemente tão baixo se a incerteza no tocante ao sucesso dos projetos cinematográficos é tão alta? As estrelas de cinema, como são chamados atores de grande impacto midiático, são mesmo capazes de alterar a estrutura de risco e o retorno de um determinado filme? Como valorar um filme e antecipar cachês de grandes talentos quando não é possível saber qual retorno uma obra irá apresentar? É possível prever quão bem sucedido será um projeto cinematográfico?

A dinâmica da geração de receitas de obras cinematográficas é tão complexa que pode, como sugere De Vany (2004), ser considerada caótica. Este mesmo autor aponta que as receitas dos filmes seguem uma dinâmica não linear que sofre uma bifurcação abrindo dois caminhos distintos possíveis para uma obra cinematográfica. O primeiro caminho conduz o filme a uma vida perene com elevado retorno financeiro, ao passo que o segundo conduz a obra a uma vida curta acompanhada de baixo retorno e não raro, a significativas perdas financeiras. 
Estas dinâmicas eventualmente convergem para um grupo de distribuições estatísticas que conjugam e avaliam riscos versus retorno, conhecidas como Distribuições Estáveis ${ }^{7}$ (DE VANY, 2004).

O termo "estável” em nada significa que o retorno financeiro do filme segue um processo bem-comportado - pelo contrário, frequentemente este comportamento é errático; mas sim que a estrutura do processo de rentabilização de uma obra cinematográfica mantém as mesmas características em todas as escalas. De Vany (2004) classifica o modelo do processo de geração de receitas de uma obra cinematográfica como uma distribuição de Pareto $^{8}$.

A distribuição de Pareto permite mostrar o quanto a incerteza está atrelada ao negócio cinematográfico e como esta incerteza afeta a organização e gestão dos elos da atividade. $\mathrm{O}$ aspecto errático caracterizado pela distribuição de Pareto sugere que a distribuição de probabilidade de retorno de uma obra cinematográfica em nada se assemelha a uma distribuição Gaussiana (ou distribuição Normal) ${ }^{9}$.

Se a rentabilização dos filmes seguisse uma distribuição Gaussiana, a maioria das obras teria retorno financeiro similar e se situaria no meio da distribuição. O filme padrão seria representado pela média e haveria pouco espaço a filmes fora do comum, tais como Central do Brasil, Chico Xavier ou Titanic, para citar um exemplo internacional. No ambiente gaussiano, um filme cujo faturamento excedesse em três desvios-padrão a média seria um caso extremamente raro e seria praticamente impossível um filme superar em quatro ou cinco desvios-padrão o retorno médio.

7 Na teoria na Probabilidade uma variável aleatória é dita estável (ou possui uma Distribuição Estável) se a combinação linear desta variável segue a mesma distribuição (WALCK, 2007).

${ }^{8}$ Originalmente utilizada para descrever a distribuição da riqueza entre indivíduos, a distribuição de Pareto - também conhecida como regra 80-20, sugere que $20 \%$ de uma determinada população controla $80 \%$ da riqueza. No entanto, a distribuição não se limita a descrever a riqueza ou distribuição de renda, sendo utilizada para descrever situações em que é encontrado um equilíbrio na distribuição de extremos (WALCK, 2007).

9 A Distribuição Normal é uma das mais importantes distribuições da estatística, conhecida também como Distribuição Gaussiana. A Distribuição Normal descreve uma série de fenômenos físicos e financeiros e é inteiramente descrita por seus parâmetros de média e desvio padrão (WALCK, 2007). 
A maioria dos filmes seria confortavelmente inexpressiva e dificilmente uma obra enfrentaria a situação de perder muito dinheiro ou de assistir a lucros espetaculares. No entanto, conforme é sabido, a indústria cinematográfica não segue tal lógica. Não existe um filme considerado padrão e médias significam muito pouco, senão nada no processo decisório acerca da estruturação de um projeto. Uma média difere da expectativa, médias de variáveis chave da indústria são altamente instáveis ao longo do tempo, valores esperados podem nem sequer existir e a variância é infinita em todas as instâncias (DE VANY, 2004).

A indústria cinematográfica é completa e amargamente não gaussiana, pois é uma indústria do extraordinário. Eventos extremos conduzem a máquina produtora de obras e todas as suas atividades adjacentes. Existe espaço para obras fora do comum, situadas na cauda elevada da distribuição de Pareto.

\subsection{Modelo Teórico}

Na presente seção serão apresentados alguns dos fundamentos microeconômicos da indústria do entretenimento, na qual está inserida a indústria cinematográfica, objeto de análise deste trabalho.

$\mathrm{Na}$ indústria do entretenimento, o fornecimento de fatores de produção, sejam eles tangíveis ou intangíveis, é diretamente afetado pela rede de capital humano disponível na região, seus custos e interações. Caves (2002) teoriza que a incapacidade de determinar o sucesso de produtos criativos com antecedência leva à formação de uma estrutura industrial caracterizada por processos de produção únicos, contratos idiossincráticos, agrupamento geográfico e formação de redes. Segundo este mesmo autor, existe a necessidade de uma ampla rede de trabalhadores, com uma gama diversificada de habilidades para atender a funções tanto artísticas como produtivas e comerciais tais como agentes, gestores, produtores, comerciantes e assim por diante. Os agentes que atuam paralelamente em processos de entretenimento podem ser vistos como partes componentes de um sistema único, implicados no objetivo final de ter o projeto concluído. A proximidade física entre os elos envolvidos nestes processos gera, sem dúvidas, valiosas economias de escopo. Economias de escopo surgem quando a mesma ideia é aplicada em processos de produção distintos, gerando diferentes produtos 
e processos de valor diferente. Em uma linguagem mais formal, o custo de uma ideia criativa pode ser disseminado através de diferentes mercados de entretenimento.

Pode-se afirmar que produtores do ramo do entretenimento possuem razões para explorar economias de escopo de modo a diluir o custo de cada ideia criativa entre diferentes projetos ou derivados destes. Economias de escopo podem ser particularmente relevantes quando a demanda regional não é suficiente para cobrir os custos relacionados à especialização necessária para a concretização de um produto tão específico, como um bem de entretenimento (um filme, peça de teatro etc). Em tais situações, um melhor aproveitamento do produto (por exemplo, através da extensão do seu ciclo de vida) pode resultar em reduções significativas dos custos médios da produção, o que evidentemente, traz benefícios competitivos à atividade produtiva.

Andersson e Andersson (2006) apontam que muitos dos processos envolvidos na produção de entretenimento abrangem uma força de trabalho altamente especializada e de custos fixos elevados, relacionados a investimentos em tecnologia, aluguéis etc. De um ponto de vista econômico, custos fixos altos exigem produção em escala para diminuir o custo fixo médio por unidade produzida, a fim de tornar viável a produção. A escala pode ser relacionada com o número de unidades produzidas e ao tamanho do mercado final, por exemplo, o tamanho do público de um filme.

Desta relação, pode-se concluir que custos fixos associados, por exemplo, à locação de um estúdio serão tanto mais diluídos quanto maior a produção de filmes neste espaço. Por outro lado, haverá um ponto de inflexão no qual a grande quantidade de filmes produzidos exigirá novos gastos em investimento e ampliação da capacidade de absorção e exibição das obras, podendo interferir no ponto ótimo. Mercados com vantagens competitivas em entretenimento precisam satisfazer duas condições:

1. Possuir demanda suficientemente grande;

2. Custos de produção baixos.

Os efeitos esperados dos maiores mercados são de dois tipos: (i) geração de economias de escala, e (ii) geração de economias de escopo no emprego de múltiplo uso da capacidade de produção. 
Economias de escala irão aumentar conforme a capacidade de absorção da região. Consequentemente, apenas regiões muito grandes podem gerar demanda suficiente para cobrir os custos relacionados a linhas de produção muito especializadas. Por um lado, o aumento da produção de entretenimento amplia a geração de economias de escopo, uma vez que há mais oportunidades para "novo trabalho a ser realizado a partir de trabalhos antigos" (Jacobs, apud Florida et al., 2009). Por outro lado, as dificuldades de administração na produção de entretenimento, também tendem a multiplicar-se, forçando as economias de escopo a diminuir na proporção que aumenta o tamanho do mercado.

Da observação destes fundamentos é possível extrair conclusões importantes que impactam a indústria do entretenimento e particularmente, a cinematográfica nos dias atuais. Levando em consideração o aparecimento e evolução dos novos suportes de difusão de conteúdo observa-se que diversas indústrias cinematográficas e notadamente a brasileira pecaram em não criar um programa robusto capaz de aliar os novos segmentos surgidos desde a segunda metade do século XX à produção cinematográfica.

Como resultado desta ausência de sinergia, observa-se não somente a não geração de economias de escala e escopo, muito benéficas à atividade produtiva, mas, sobretudo, a constituição de um cenário predatório entre a indústria cinematográfica e os novos segmentos do audiovisual, na medida em que sem interação, estes se tornam concorrentes diretos.

O Capítulo 3 apresentará o processo de constituição da indústria cinematográfica enquanto tal e as dificuldades levantadas com o advento da indústria do audiovisual após a aparição e evolução dos novos suportes de difusão. Por fim, será feita uma análise dos impactos destas novas janelas na indústria cinematográfica. 


\section{INSUSTENTABILIDADE DA INDÚSTRIA DO CINEMA? 0 ADVENTO DA INDÚSTRIA AUDIOVISUAL E SUAS CONSEQUENCIAS}

No segundo capítulo foi feita uma apresentação da indústria do Cinema, através da exposição das características econômicas e financeiras dos seus principais agentes (produtor, distribuidor e exibidor). Em seguida foram avaliadas as formas como se dão a geração e redistribuição das receitas dentro do ciclo produtivo e as dificuldades encontradas pelos agentes atuantes nesta indústria em estimar o retorno de seus projetos. Por fim, foi apresentado um breve Modelo Teórico aplicável à indústria do Entretenimento e notadamente à indústria cinematográfica, apresentando os insumos tangíveis e intangíveis presentes na atividade produtiva de um bem cultural os benefícios das economias de escala e escopo para a indústria como um todo.

No capítulo 3 serão apresentados alguns aspectos inerentes à atividade cinematográfica que evidenciam a sua fragilidade e dificultam e muitas vezes até mesmo impedem a ocupação de um posicionamento autossustentável da indústria. A necessidade de aportes financeiros que fogem ao comum, somada à forte incerteza no que toca o retorno dos investimentos são duas das diversas razões que tornam a interferência externa à atividade cinematográfica um imperativo. Será feita uma análise da evolução pela qual a indústria do cinema atravessou - notadamente após a aparição de novos suportes de difusão, e expostas as implicações decorrentes deste processo.

Através de comparação com a trajetória delineada pela indústria cinematográfica norte-americana pretende-se compreender quais fatores possibilitaram a ascensão desta indústria de cinema a uma posição forte e consolidada em contraponto com a indústria brasileira, historicamente frágil e dependente das políticas de fomento do Governo.

A seção 3.1 realiza uma análise de características intrínsecas à economia do cinema que tornam a intervenção externa à atividade necessária na maioria dos países para garantir a sua realização e sustentabilidade. A seção 3.2 apresenta a evolução da indústria do cinema desde os marcos iniciais no século XIX até sua afirmação enquanto 
indústria e as dúvidas levantadas com o aparecimento das novas janelas de difusão iniciada com o surgimento e penetração dos aparelhos televisores nos lares a partir dos anos 1920. A seção 3.3 aborda o processo de aparição dos novos suportes e a constituição da indústria do audiovisual propriamente dita. Por fim, a seção 3.4 expõe o processo de adaptação dos agentes atuantes na indústria do cinema dos Estados Unidos à nova conjuntura e como a indústria cinematográfica norte-americana foi bem sucedida neste sentido.

\subsection{Justificativa histórica do sistema de auxílio à produção cinematográfica}

A percepção da necessidade de intervenção nos planos de financiamento da produção cinematográfica foi resultado do julgamento de alguns aspectos intrínsecos ao setor, que serão expostos a seguir.

\subsubsection{Características estruturais da economia do cinema}

No tocante à posição incerta da indústria cinematográfica Benhamou (2003) aponta:

"A fragilidade econômica do setor, alimentada pelo crescimento dos custos e pela quase ausência de reservas de produtividade, justifica sem dúvida a amplitude das ajudas públicas e do recurso ao mecenato [...] Esta intervenção massiva, repartida de forma muito desigual, não é suficiente para garantir ao setor um equilíbrio financeiro durável” (p. 28)

A análise retrospectiva da indústria do cinema põe em evidência alguns elementos determinantes para a dinâmica do setor.

Em primeiro lugar, a indústria cinematográfica apresenta, como já mencionado no capítulo introdutório, aspectos ditos de "cassino" (LECLERC, 2003, p.12). A atividade caracteriza-se, por um lado, pela forte incerteza dos resultados - fruto da dificuldade em prever a recepção dos filmes pelo público e pela crítica, e por outro, por uma proporção minoritária de grandes sucessos, que mascara a baixa rentabilidade média dos filmes, através da diluição estatística dos resultados. 
Em segundo lugar, a necessidade de investimentos muito elevados - que supera em diversas vezes a necessidade de investimento em diversas outras indústrias; aumenta, evidentemente, os riscos da atividade.

Em terceiro lugar, como sugerido por William Baumol e William Bowen (BAUMOL, BOWEN, 1969 apud BENHAMOU 2003, p. 28) ${ }^{10}$, a indústria do entretenimento (na qual o cinema está inserido) apresenta uma evolução de custos nitidamente inflacionista que se conjuga a uma forte rigidez nos preços de venda - o ajuste entre oferta e demanda dos filmes não sendo operado via preços. O preço da entrada dos filmes nas salas de exibição é fixo e único, independentemente dos custos de produção da obra e do seu mercado potencial.

Acerca da constatação empírica do crescimento permanente dos custos relativos de pessoal na indústria cinematográfica decorrente da impossibilidade desta em gerar ganhos de produtividade, Baumol e Bowen destacam: "Diferentemente dos trabalhadores das indústrias, os artistas não são intermediários entre a matéria-prima e o produto final. Suas atividades são, elas próprias, o bem daquele que as consome" (1966, apud BENHAMOU, 2003, p. 32).

A oferta de filmes nos canais abertos de televisão, por sua vez, é viabilizada através do pagamento de direitos de difusão, cuja taxa não é diretamente atrelada ao equilíbrio econômico do setor cinematográfico.

Por fim, é importante assinalar que as diferentes formas de consumo dos filmes, sejam a projeção em salas, a venda ou a locação e a difusão televisionada, são, em grande medida, substitutas e, portanto, concorrentes diretas à atividade cinematográfica.

${ }^{10} \mathrm{O}$ estudo pioneiro no campo da Economia da Cultura foi resultado de uma consultoria prestada pelos economistas Baumol e Bowen (1969) à Fundação Ford. O estudo, denominado Performing arts: the economic dilemma, defende o subsídio às artes pelo fato de as atividades artísticas serem intensivas em trabalho, ao contrário de outros setores, nos quais a utilização intensiva da tecnologia possibilita a geração de ganhos de produtividade e consequente diminuição de custos. Em linhas gerais, o estudo chega à conclusão de que o setor das artes padece da chamada doença dos custos. Por um lado, observa-se uma crescente curva de custos variáveis - gerada pela elevada necessidade de aportes tecnológicos e pelos encargos de profissionais especializados. Por outro lado, a estrutura do setor, bastante intensiva em trabalho, apresenta grandes dificuldades na geração de ganhos de produtividade; diferentemente do observado na maioria das demais atividades industriais. Em tom anedótico os autores afirmavam que "não é possível aumentar a produção de concertos, cortando violinos ou oboés de uma orquestra" (Baumol; Bowen, op. cit., p.163). Esse descompasso entre os dois setores gera uma crescente disparidade entre custos e receitas e, consequentemente, a instauração de uma "crise permanente" no setor das artes tradicionais. 
A combinação de todos esses motivos - mercado restrito, riscos elevados, baixa rentabilidade e a aparição de suportes de difusão concorrentes; rapidamente levou à constatação de que a indústria cinematográfica despertava pouco interesse ao setor financeiro e que a sua sustentabilidade dependeria quase que necessariamente de intervenções externas à atividade (BENHAMOU, 2007).

3.2 Evolução histórico-estrutural da indústria cinematográfica: da hegemonia francesa à hegemonia norte-americana e à convergência audiovisual

A seção anterior apresentou características estruturais da indústria cinematográfica, que evidenciam a fragilidade desta indústria e justificam a insuficiência verificada por diversas cinematografias nacionais na ambição de tornaremse autossustentáveis. A presente seção visa a observar a trajetória de evolução e afirmação da indústria do cinema enquanto tal, assumindo como referência as indústrias cinematográficas francesa - devido ao pioneirismo desta na estruturação da nova atividade industrial; e a norte-americana devido ao posicionamento hegemônico autossustentável ocupado graças à adoção de medidas e à implementação de políticas que, conjugadas, foram capazes de solidificar e manter a atividade cinematográfica norte americana como a mais pujante do mundo.

A trajetória histórica de fortalecimento do cinema enquanto atividade industrial será analisada a partir da exposição de dois marcos fundamentais, sejam eles a conformação e afirmação da hegemonia dos Estados Unidos no campo da cinematografia após o fim da I Grande Guerra e a constituição do processo de convergência audiovisual em processo acelerado de expansão desde a primeira metade do século XX (MATTA, 2008). Para tanto será feita uma breve revisão histórica da solidificação da indústria do cinema através da apresentação dos seus marcos estruturais, da composição da hegemonia francesa até a alternância para a hegemonia norte-americana no pós I Guerra e a constituição do percurso de convergência, com o desenvolvimento e afirmação da indústria audiovisual.

A indústria cinematográfica foi, desde o seu princípio, forjada a partir de mudanças e adoção de técnicas e recursos inovadores os quais foram tornando-se mais complexos e sofisticados ao longo do tempo. A dinâmica produtiva foi e continua sendo permanentemente moldada às exigências e novos desafios do setor e o impacto ocasionado por todas estas transformações nos âmbitos social, econômico e cultural é 
flagrante. A compreensão da indústria cinematográfica, da sua evolução e dos desafios enfrentados atualmente, notadamente no Brasil, passa inevitavelmente pela avaliação dos marcos históricos atravessados pelo setor através dos anos. A aparição de novos suportes de difusão a partir da primeira metade do século XX e em curso acelerado até os dias atuais gerou novos desafios e encaminhou a indústria cinematográfica para o percurso da convergência audiovisual, onde a sinergia e a velocidade de adaptação tornaram-se elementos imprescindíveis para a ambição de uma trajetória autossustentável.

O aparecimento do cinema na Europa Ocidental e na América do Norte foi, segundo Gomes (1996),o sinal de que a Revolução Industrial estava prestes a estenderse ao campo do entretenimento. De fato, o surgimento da nova forma de lazer representada pelo advento do cinema no final do século XIX pode ser considerado, conforme sugere Rosenfeld (2002), como o marco da aparição da indústria do entretenimento, cuja importância em termos de movimentação de recursos financeiros, humanos e de impactos na sociedade é de extrema relevância.

A despeito dessa interpretação acerca da indústria do cinema como uma atividade industrial econômica voltada à satisfação da demanda do homem moderno por lazer, a aparição do cinema se deveu a aspirações científicas de pesquisadores e cientistas que visavam a aplicar a reprodução de imagens à ciência e não necessariamente tinham em mente que uma nova indústria da diversão derivaria destes esforços (MANNONI, 2000).

Conforme assinala Matta (2008), quando no ano de 1895 os irmãos Lumière fizeram em Paris a primeira demonstração pública do cinematógrafo ${ }^{11}$, pensavam ter em mãos um instrumento de pesquisa a ser aplicado a campos diversos da ciência, através da possibilidade de reproduzir a realidade em dimensão real. Georges Méliès, um ilusionista francês de grande sucesso e um dos precursores do cinema foi o primeiro a desenvolver e exibir filmes com o intuito expresso de gerar bens de entretenimento.

Enquanto a contribuição de Méliès foi notável na afirmação da atividade cinematográfica como instrumento de lazer, o desenvolvimento da atividade industrial propriamente dita deve muito a Charles Pathé (MANNONI, 2000). A companhia de

\footnotetext{
${ }^{11}$ Aparelho híbrido, capaz de associar funções de máquina de filmar, de revelação de películas e de projeção de fotogramas em série, criando a ilusão de movimento. A invenção do cinematógrafo constitui o marco inicial da história do cinema.
} 
Pathé esteve à frente da evolução da dinâmica organizacional da atividade cinematográfica no século XIX, sendo responsável pela estruturação de grande parte da conformação atual da indústria. Durante a primeira década daquele século, as obras produzidas eram comercializadas diretamente junto aos exibidores. Conforme foram sendo formados trustes ${ }^{12}$ horizontais que passaram a assumir o domínio do elo da produção, os produtores foram percebendo que o aluguel das obras era consideravelmente mais rentável do que sua venda definitiva. Neste contexto surge a figura intermediária fundamental do elo da cadeia produtiva cinematográfica, o Distribuidor, apresentado anteriormente (MATTA, 2008).

Observando a lógica da estruturação industrial de Pathé é possível identificar alguns elementos que possibilitaram a constituição da hegemonia francesa que perdurou até a eclosão da I Grande Guerra. Tal lógica foi aproveitada e replicada por Hollywood, onde a segregação dos elos fundamentais garantiu a firmação da atividade cinematográfica como negócio bem estruturado bem como possibilitou notável ampliação do faturamento. Além disso, estratégias tais como a constituição de oligopólios $^{13}$ - através da formação de trustes horizontais ou verticais; caracterizaram tanto a hegemonia francesa como posteriormente a norte-americana.

Em meados do século XIX a França encontrava-se em estado avançado do processo de industrialização e sua população contava com elevado poder aquisitivo, de maneira que o mercado interno conseguia cobrir os custos dos investimentos e demais gastos com a produção. Este fato garantia não somente a perenidade de recursos para a realização de novos projetos, mas também a possibilidade de comercialização de cópias das obras para outros países a preços relativamente menores (BERNARDET, 2001). Tal equilíbrio autossustentável foi, conforme destaca Matta (2008), fundamental para a ocupação da posição hegemônica da cinematografia francesa, que só foi abalada após o advento da I Guerra Mundial, em 1914.

Com as economias europeias adaptando-se radicalmente aos esforços de guerra, engendrou-se uma nova conjuntura político-econômica que foi eficientemente aproveitada pelos EUA. Aproveitando e adaptando o pioneirismo estrutural da indústria cinematográfica francesa, o cinema norte-americano desenvolveu notável potencial

\footnotetext{
${ }^{12}$ Fusão de empresas inseridas em uma mesma atividade.

${ }^{13}$ Estrutura de mercado de concorrência imperfeita, caracterizada por um número restrito de empresas produtoras que controlam o mercado.
} 
técnico e diversificada carteira de gêneros com apelo de massa dos quais se destacam os happy end, os filmes de faroeste e de ação (ROSENFELD, 2002). Estes aspectos, conjugados, satisfizeram como nunca antes visto por nenhuma cinematografia nacional as expectativas do público adquirente deste novo serviço. Conforme destaca Rosenfeld (2002), a dimensão do mercado interno norte-americano e o seu elevado poder aquisitivo desempenharam, tal qual na França no século XIX, importante papel na consolidação da atividade e ascensão à posição hegemônica de Hollywood. A marca da repetição, característica industrial aplicada à atividade cinematográfica constituiu outro artifício importante adotado como meio de mitigar incertezas desta atividade que a despeito de seu caráter arriscado e custos elevados, ainda era muito atraente em decorrência da possibilidade de grandes retornos (MATTA, 2008). Concentrada num primeiro momento em Nova Iorque, a produção cinematográfica foi paulatinamente sendo transferida para o oeste dos EUA, onde as vantagens geográficas e de custo se mostraram rapidamente benéficas à atividade.

O resultado deste habilidoso aproveitamento e adaptação de recursos técnicos, organizacionais e artísticos foi um público crescente tanto em esfera nacional como internacional e a inserção em um percurso que culminou na ocupação da posição hegemônica da atividade cinematográfica norte-americana, que perdura até a atualidade (DE VANY, 2004).

No pós Guerra, os agentes da cadeia cinematográfica de menor envergadura foram sendo progressivamente expostos às pressões das grandes empresas e absorvidos ou eliminados pelos trustes financeiros que estavam no topo da lógica estrutural sobre a qual se desenvolveu a indústria cinematográfica dos Estados Unidos dos anos vinte até o final da primeira década do século XX. O sistema de estúdios desenvolvido pelas empresas de maior porte buscou verticalizar toda a cadeia e, numa representação de organização de interesses, foi criada, no ano de 1922, a Motion Picture Association of America (MPAA), associação voltada a defender as aspirações do segmento cinematográfico em território americano e no resto do mundo.

Em uma trajetória de aprofundamento do processo de verticalização - através da incorporação de todas as etapas produtivas; foram utilizadas práticas anticompetitivas nos contratos estipulados junto aos elos com menor poder de barganha do setor cinematográfico norte-americano. De tais práticas, destacam-se o block-booking e o blind-booking, que estabeleciam o aluguel de pacotes de filmes ainda não concluídos 
para exibição e o aluguel de filmes em pacotes fechados que não permitiam a prévia seleção por parte do exibidor respectivamente (BORNER, 1983).

Tendo atingido o seu auge nos anos vinte, o sistema de estúdios de Hollywood vivenciou nova experiência de renovação com o advento do cinema falado e a incorporação do elemento sonoro ao contexto cinematográfico, fato que revigorou de maneira significativa a frequência às salas nos anos que se seguiram. Os importantes investimentos necessários para realizar a transição do cinema mudo ao cinema falado, juntamente aos efeitos da crise de 1929 só fizeram ampliar o domínio de mercado das grandes companhias de Hollywood, denominadas majors (VOGEL, 1998).

A trajetória de monopólio das majors só foi limitada quando, no ano de 1948, as práticas de concentração foram legalmente vetadas pela Suprema Corte de Justiça americana no que ficou conhecido como processo da Paramount. A nova regulamentação estipulou a separação entre os elos da cadeia produtiva o que alterou profundamente a organização e os rumos da cinematografia norte-americana (BORNEL, 1983). Como consequência das imposições derivadas do processo da Paramount assistiu-se à renúncia do modelo fordista implementado pelos grandes estúdios à lógica da produção cinematográfica nas décadas anteriores. Nos anos cinquenta a indústria cinematográfica já adotava um modelo mais flexível onde diversas das atividades antes realizadas em uma das fatias da organização vertical dos estúdios foram transferidas para o mercado e os contratos já eram definidos a cada projeto (DE VANY, 2004).

Além do forte abalo que o processo da Paramount ocasionou à estrutura de concentração de atividades e ganhos constituída pelas majors americanas desde o final da I Guerra outro fato relevante se conjugou a conjuntura vivenciada pela indústria cinematográfica no final da primeira metade do século XX: a popularização e penetração dos aparelhos televisores nos lares. A proibição da verticalização dos elos da cadeia cinematográfica - produção, distribuição e exibição, em 1948, levou ao desenvolvimento de maiores sinergias entre produtores e distribuidores, que precisaram se articular face ao desenvolvimento e popularização do elo da exibição, agora representado pela demanda de duas mídias diferentes: cinematográfica e televisiva. Em decorrência da concorrência direta gerada pela aparição e disseminação da televisão, o elo da distribuição ganhou fortemente em importância, na medida em que se tornou a etapa essencial capaz de obter vantagens competitivas no encaminhamento da produção 
da indústria do cinema, agora com maiores riscos e incertezas quanto à demanda (SQUIRE, 2004).

3.3 A aparição de novos suportes e a constituição da indústria audiovisual

Na presente seção será exposta a trajetória de aparição e evolução de novos suportes de difusão de conteúdo programático que ampliou as dificuldades do setor cinematográfico e avaliados os impactos desses na indústria de cinema.

\subsubsection{As novas janelas de exibição}

Os anos cinquenta marcaram a entrada dos aparelhos de TV nos lares representando uma revolução no entretenimento doméstico. Ainda nesta década, a indústria cinematográfica já passou a ser encarada como parte componente de uma indústria mais ampla e complexa: a indústria do audiovisual. A evolução da tecnologia foi intensa e ininterrupta nas décadas que se seguiram e o resultado deste processo foi o aparecimento de novos formatos de produção de conteúdo e suportes de difusão audiovisuais. Em decorrência destas mudanças a estrutura competitiva da indústria cinematográfica foi profundamente alterada e a dinâmica do audiovisual passou a envolver a produção e adaptação de conteúdo para exibição não mais apenas nas salas de cinema, mas também nas novas janelas de difusão como a televisão aberta, a televisão por assinatura, vídeo e posteriormente, as mídias digitais como DVDs e transmissões via internet e telefonia móvel. 
A figura 4 apresenta o organograma com a estrutura organizacional da indústria do audiovisual.

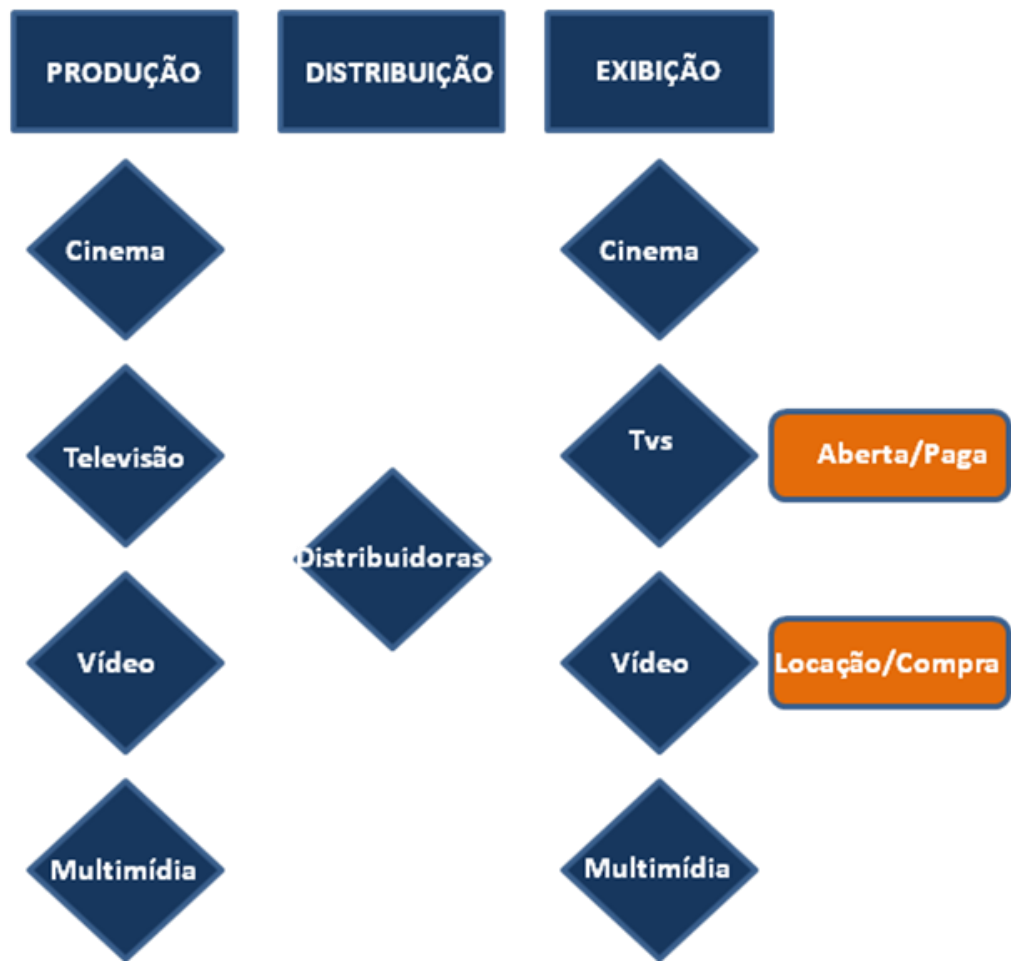

Figura 4: Cadeia da indústria do audiovisual

Fonte: Elaboração própria a partir de Squire (2004)

A tecnologia da televisão já existe desde o final dos anos 1920. Entretanto, conforme assinala Ochiva (2004) somente após a II Guerra Mundial a produção de aparelhos televisores tornou-se massiva, em um processo que marcou o início da indústria de produção de conteúdo para a televisão. Já no primeiro ano de disponibilização, 1946, 17 mil aparelhos de TV foram vendidos. Menos de uma década depois, dois terços dos lares americanos já possuíam ao menos um aparelho de TV. Estações de transmissão desenvolveram-se de maneira acelerada, auxiliadas pela forte injeção de recursos oriunda de campanhas de propaganda atraídas por esta nova e representativa audiência domiciliar. Nos dias atuais, estima-se que $98 \%$ dos lares estejam equipados com ao menos um aparelho de TV, e que os consumidores dedicam cerca de $40 \%$ do seu tempo livre assistindo televisão (Ochiva in Squire, 2004). 
As consequências da aparição e disseminação dos aparelhos de televisão se fizeram rápida e fortemente sentir já nos primeiros anos em que as salas de exibição deixaram de ocupar a posição de principal veículo de entretenimento.

A análise dos efeitos sobre a frequentação às salas de exibição após o advento da televisão já evidencia o quanto este novo marco afetou estruturalmente a indústria cinematográfica. No entanto, em se tratando de uma trajetória evolutiva tecnológica natural, é preciso pensar nas implicações de forma mais progressista e não atribuir à televisão ou aos demais suportes de exibição a inteira culpa das deficiências e limitações do cinema. Se por um lado a captura de público das salas de exibição por parte da televisão foi flagrante, por outro esta última se transformou em mais uma janela de transmissão de conteúdo da indústria do cinema e, portanto, em possibilidade de alongamento do ciclo de vida do produto cinematográfico. A consolidação da integração e das interelações entre as indústrias do cinema e da televisão, conjugadas às transformações tecnológicas em curso ininterrupto, marcam o nascimento da indústria audiovisual, em desenvolvimento e evolução permanente até os dias atuais.

Diferentemente da maioria das cinematografias nacionais, notadamente a brasileira, a indústria cinematográfica norte-americana soube reagir rápida $\mathrm{e}$ positivamente às mudanças às quais foi exposta com o advento da televisão e com o desenvolvimento acelerado da indústria do audiovisual que se sucedeu (VOGEL, 1998). Um aspecto fundamental na condução da atividade cinematográfica por Hollywood foi a habilidade na percepção e compreensão da nova conjuntura e consequente adaptação a ela. Já no início dos anos sessenta a indústria cinematográfica norte-americana foi capaz de incorporar à sua lógica o surgimento da televisão e realizar ajustes para proteger-se e mesmo obter vantagens nesse novo contexto (MATTA, 2008).

Um fator relevante na proteção da cinematografia norte-americana foi, segundo Matta (2008), o respaldo da regulamentação da Federal Comunications Comission ${ }^{14}$ (FCC), que até o ano de 1993 proibiu que a produção e distribuição de programas pelas próprias redes de televisão ultrapassassem o patamar de 30\%. Como esta cota era rapidamente esgotada (programas de fins jornalísticos e esportivos já atingiam a cota),

\footnotetext{
${ }^{14}$ Criado em 1934, dentro do programa New Deal, a Federal Communications Commissions (FCC) é o órgão regulador da área de telecomunicações e radiodifusão dos EUA.
} 
havia grande espaço para a aquisição de obras oriundas da indústria cinematográfica (MATTA, 2008).

A indústria de Hollywood foi, portanto, pioneira na adaptação da produção cinematográfica à crescente demanda por conteúdo programático das emissoras de TV. A renda obtida através da venda de direitos de difusão às emissoras transformou-se em relevante fonte de renda para o elo da produção do cinema, que habilmente soube adaptar seus recursos e capacidade produtivos a esta bifurcação do elo exibidor. Como resultado desta percepção, verificou-se a consolidação da integração entre as mídias cinematográfica e televisiva a partir dos anos sessenta, auxiliada pelo governo norteamericano, o qual soube reconhecer a importância da indústria cinematográfica e administrar as medidas necessárias para protegê-la. A consequência das ações do governo foi o desenvolvimento de fortes sinergias entre as duas mídias: cinema e TV desenvolveram-se como vertentes de produção distintas, porém apoiadas na mesma estrutura principal, conformando e consolidando a indústria do audiovisual.

Na medida em que a nova configuração da indústria audiovisual se consolidava e expandia, a indústria de cinema precisou refletir seu posicionamento e definir novas estratégias, em um processo que resultou na transformação do papel desempenhado pelas salas de exibição, marcado notadamente pela introdução de diferenciais técnicos na exibição nas salas. A internalização da lógica da nova indústria audiovisual, mais ramificada e abrangente, na qual as salas de exibição não mais constituíam a única janela de difusão de conteúdo audiovisual foi fundamental no processo de reversão da diminuição de expectadores das salas de cinema. A rápida compreensão e absorção da nova dinâmica audiovisual pela indústria cinematográfica norte-americana garantiu um posicionamento adequado desta indústria e o investimento a tempo no desenvolvimento de novas estratégias de distribuição de conteúdo (BAUMGARTEN et al., 2004).

Se em um primeiro momento o cinema norte-americano se concentrava na produção de obras destinadas às massas, já a partir do pós I Guerra as produções de Hollywood passaram ser pensadas para nichos de mercado mais específicos. Dentre uma diversidade, destacam-se dois segmentos de mercado que se desenvolveram com maior força, sejam os filmes de arte e os filmes voltados para adolescentes e jovens adultos (MINC, 2003). Os filmes de arte passaram a contar com um público exigente, 
porém cativo e significante, na medida em que a televisão atendia mais do que satisfatoriamente a demanda por conteúdo de massa, tendo rapidamente destronado o cinema como veículo deste tipo de conteúdo e abrindo espaço para o desenvolvimento dos filmes de autor. Conforme destaca Matta (2008), as produções destinadas ao público jovem se firmaram como gênero estratégico e lucrativo nos anos setenta, originando os chamados blockbusters, que até hoje representam um pilar fundamental da indústria cinematográfica norte-americana e simboliza o poder econômico das majors. (MINC apud MATTA, 2008).

O avanço tecnológico acelerado e a consolidação da indústria audiovisual através do surgimento e aprimoramento de novas mídias impulsionou o desenvolvimento de novas estratégias para o mercado de cinema. A estrutura de custos de produção foi modificada com os blockbusters - as produções passaram a contar com orçamentos cada vez mais elevados e a ênfase nas campanhas de marketing tornou-se elemento de fundamental importância (VOGEL, 1998).

Neste momento de evolução das estratégias de lançamento dos filmes a orçamentos elevados surge o novo conceito de exibição de obras: o multiplex. Caracterizado por um complexo de exibição, o multiplex conta com um número elevado de salas situadas em um mesmo empreendimento comercial, onde além da atividade de exibição propriamente dita, a disponibilização de serviços acessórios como venda de alimentos e outras atividades menores de lazer como máquinas de jogos etc, possibilitam a captura e acomodação de clientes que eventualmente não consigam obter ingressos ou não se interessem pelos filmes em cartaz, garantindo assim a obtenção de receita. Matta (2008) destaca que o modelo multiplex possibilitou maior eficiência e eficácia nos lançamentos dos filmes, notadamente dos blockbusters (MATTA, 2008, p. 13).

Outra estratégia desenvolvida pela indústria cinematográfica como decorrência da evolução das novas mídias foi o windowing (janelas). Nesta estratégia, a posição primária do mercado de exibição é ocupada pelas salas de cinema e após serem comercializados e exibidos nas salas de exibição, os filmes são novamente comercializados para os mercados subsequentes com custos adicionais menos elevados, atingindo, progressivamente, as diferentes janelas de exibição domésticas: vídeos e DVDs, TVs pagas, TVs abertas nacionais e estrangeiras e quaisquer outras mídias 
(transmissões via internet, telefones celulares, etc.) (BRITZ, BRAGA, DE LUCA, 2010).

As salas de exibição auferem atualmente cerca de $18 \%$ das receitas totais da indústria cinematográfica; o restante da receita cabendo às janelas subsequentes. Apesar desta representatividade aparentemente pouco elevada, o glamour e o efeito do lançamento nas salas impacta diretamente o desempenho das obras nos mercados subseqüentes (MPAA, 2004).

A despeito da capacidade de assimilação da nova conjuntura audiovisual e rápida adaptação a ela, alguns previam e prognosticavam o fim da indústria de cinema de Hollywood. Tal fato, no entanto, nunca ocorreu, e o que se observou foi a reinvenção da indústria cinematográfica, através da reestruturação da atividade e sua centralização nas atividades relacionadas à distribuição de conteúdo haja vista o posicionamento estratégico que este elo passou a representar. A produção de filmes passou a seguir uma estrutura de pacotes os quais eram financiados pelas distribuidoras com base em suas estratégias de negócio.

Ao longo do processo de adaptação, observou-se a firmação de uma nova dinâmica do elo distribuidor. Por meio de fusões e aquisições as distribuidoras de grande porte foram se transformando em conglomerados de entretenimento, englobando atividades de lazer que extrapolavam o domínio do cinema, assumindo como estratégicos também os ramos da televisão, produção e gravação musical, esporte e turismo. A atividade cinematográfica esteve, conforme mencionado anteriormente, à origem da indústria do entretenimento e contribuiu para a evolução e afirmação da indústria audiovisual, através da absorção de sua lógica e adaptação a ela (DE VANY, 2004).

A respeito deste processo Neves (2003) resume: Hollywood [...] soube adaptarse institucionalmente às consequências da evolução tecnológica ao compreender muito rapidamente que cada novo suporte representava uma tremenda revitalização de seus ativos, pois permitia novos ciclos de vida comercial aos seus catálogos (NEVES, 2003, p. 90). 
De fato, a partir dos anos 70, quando os novos suportes de difusão começaram a despontar como revolucionários elementos de lazer doméstico - liderados pelos emblemáticos home video e TV a cabo, as distribuidoras majors já haviam assimilado o novo contexto representado pela abrangente indústria do audiovisual e executado as manobras necessárias para ajustar-se a ele, notadamente através da percepção e do posicionamento do elo da distribuição como elemento chave da competitividade do setor. A adaptação em tempo adequado possibilitou à indústria de Hollywood colher os benefícios da existência de mídias distintas de exibição ao distribuir conteúdo audiovisual para os diferentes suportes (DE VANY, 2004).

Com o advento da indústria audiovisual e incorporação da indústria cinematográfica por aquela primeira, a melhor compreensão e, consequentemente, a adaptação mais adequada das políticas e estratégias desta segunda dependem da observância do novo contexto estrutural. Ao assimilar a dimensão e a abrangência da indústria do audiovisual, observa-se que o desenvolvimento de políticas que fortalecem a indústria cinematográfica desempenha efeito semelhante na indústria audiovisual como um todo. O valor que o produto cinema representa tanto do ponto de vista social como econômico se torna flagrante ao se constatar que ele constitui o único serviço audiovisual que atinge todas as principais janelas de exibição de conteúdo (SQUIRE, 2004).

A Figura 5 apresenta de forma esquemática a consolidação da indústria do cinema e sua evolução até o processo de convergência audiovisual nos EUA.

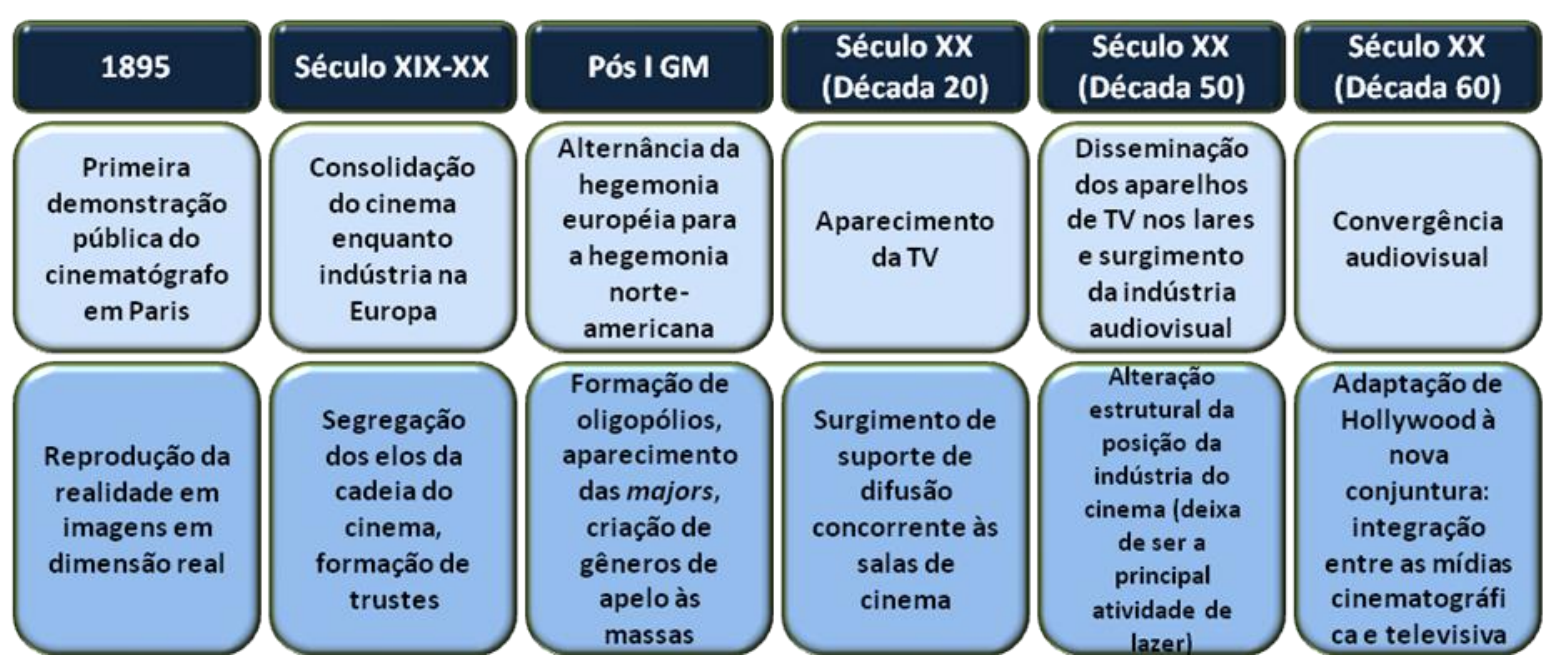

Figura 5: Conformação da indústria cinematográfica e convergência audiovisual Fonte: Elaboração própria 
O presente capítulo buscou mostrar que a configuração da hegemonia da atividade cinematográfica nos Estados Unidos e o processo de convergência audiovisual constituem dois fatores estruturais essenciais para a compreensão da dinâmica na qual a atividade cinematográfica como um todo está inserida. $\mathrm{O}$ entendimento do processo de conformação histórica dos fatores que garantiram à cinematografia norte-americana a sua adaptação e perenidade em um contexto de constante evolução e novas perspectivas é fundamental para a definição de diretrizes e formulação de políticas eficazes para a condução da atividade. As tentativas de reflexão e definição de novas propostas para o setor cinematográfico que não considerem estes elementos tendem a ser inócuas e insuficientes na proposta de traçar um caminho sustentável para a atividade (MATTA, 2008). 


\section{CONSOLIDAÇÃO DA INDÚSTRIA CINEMATOGRÁFICA BRASILEIRA: INEFICÁCIA NO DESENVOLVIMENTO DE UMA TRAJETÓRIA SUSTENTÁVEL}

O capítulo 3 apresentou aspectos inerentes à atividade cinematográfica que tornam evidente a fragilidade desta indústria e dificultam ou mesmo impedem, conforme observado na maioria dos países, a sua inserção em uma trajetória autossustentável. Foi feita uma análise da trajetória de afirmação e evolução da indústria do cinema propriamente dita, assumindo como referência as indústrias cinematográficas francesa num primeiro momento e a norte-americana num segundo devido ao pioneirismo daquela primeira e à pujança atingida por esta segunda. Buscouse identificar os elementos que possibilitaram a ascensão e perenidade da hegemonia da indústria de Hollywood a despeito do desconfortável contexto de ascensão da indústria audiovisual na primeira metade do século XX e compreender as adaptações feitas por esta indústria no intuito de aderir à nova dinâmica de convergência audiovisual.

A partir desta análise elaborada no capítulo 3, pretende-se, no presente capítulo, avaliar a trajetória de consolidação da indústria cinematográfica brasileira e identificar os aspectos que contribuíram para que o cinema brasileiro permanecesse fortemente dependente do auxílio do Governo e não lograsse na ambição de consolidar uma trajetória sustentável. Para tanto, serão analisadas na seção 4.1 as primeiras iniciativas adotadas em prol da indústria do cinema brasileiro até o golpe militar e a instauração da ditadura no Brasil. Na seção 4.2 serão apresentadas as medidas adotadas durante o regime militar, com destaque para o papel desempenhado pela Empresa Brasileira de Filmes (Embrafilme). A seção 4.3 abordará as políticas implementadas a partir da década de 1990 as quais viabilizaram a retomada da produção nacional após anos de estagnação.

Conforme exposto anteriormente, a presente dissertação se baseia na hipótese de que as políticas federais de fomento à indústria de cinema no Brasil não têm sido eficazes no intuito de melhorar a competitividade dos filmes brasileiros e inserir a atividade cinematográfica nacional em uma trajetória de mercado autossustentável. A 
questão da distribuição e comercialização dos filmes nacionais constitui um gargalo permanente e a despeito das diversas tentativas de fomento à atividade cinematográfica nacional, observa-se que as iniciativas para regular a indústria do cinema e provocar a convergência entre esta e os demais elos da indústria do audiovisual nacional são insuficientes. Em não desenvolvendo o elo da distribuição e não provocando a convergência entre os elos da cadeia do audiovisual, as políticas federais não têm encontrado êxito na ambição de desenvolver uma indústria cinematográfica nacional forte e consolidada.

Os anos cinquenta marcaram a penetração dos aparelhos televisores nos lares e já a partir desta década, a indústria do cinema passou a ser entendida como uma das vertentes de uma nova indústria, mais ampla e abrangente, a indústria do audiovisual. A dinâmica produtiva do cinema sofreu profunda transformação e dentre as principais consequências, observou-se o aumento da importância do elo da distribuição haja vista seu caráter estratégico na manutenção da competitividade da produção cinematográfica (DE VANY, 2004). A este respeito Marques (2009) destaca:

\footnotetext{
"Sem uma estratégia de comercialização, calcada não só em dados e características da produção em si, mas principalmente em informações do mercado exibidor, a probabilidade de a obra cinematográfica não ser lançada é alta”. (p.35)
}

A evolução tecnológica ao longo das décadas subsequentes só fez intensificar o processo de expansão da indústria audiovisual, alimentada pelo surgimento de novas plataformas de exibição e formatos de produção adaptados a elas. Consequentemente, a dinâmica competitiva da indústria cinematográfica como um todo passou a envolver, conforme apresentado no capítulo 3, a produção e distribuição de filmes para exibição nas diferentes janelas do audiovisual (SQUIRE, 2004).

A eficácia das políticas de apoio à indústria de cinema está diretamente sujeita à compreensão e assimilação da nova dinâmica produtiva surgida com o advento da indústria do audiovisual e do melhor aproveitamento do produto cinematográfico, através da inserção deste nas diferentes janelas de exibição e consequente extração de todo o seu valor comercial (BRITZ, BRAGA, DE LUCA, 2010). 
4.1 As primeiras iniciativas em prol da indústria do cinema brasileiro

Já no início do século XX a deficiência competitiva da produção cinematográfica brasileira em relação às cinematografias europeia e norte-americana nas salas revela-se um fato. Com a eclosão da I Guerra Mundial este cenário de baixa competitividade torna-se ainda mais acirrado na medida em que, com a ascensão da indústria cinematográfica norte-americana à posição hegemônica, o espaço para a comercialização de obras nacionais e de outros países torna-se mais limitado (GOMES, 1996).

Dentro de tal conjuntura, sob o governo Vargas, foi lançada a primeira política pública voltada para o fomento da atividade cinematográfica nacional: a introdução do sistema de cotas de tela. Este dispositivo, igualmente adotado em outros países, objetiva assegurar um patamar mínimo de mercado para a produção cinematográfica nacional a partir da obrigatoriedade de exibição. No auge da inserção da cinematografia brasileira nas salas, nos anos 80, atingiu-se a obrigatoriedade de cada sala ter em sua carteira de exibição filmes brasileiros durante 140 dias por ano (MATTA, 2008).

Apesar da introdução do sistema de cotas ter gerado um incentivo à classe produtora, Simis (2008) destaca que a intervenção do Estado ainda estava longe de direcionar a atividade cinematográfica nacional para o caminho da plena consolidação do setor. Embora a obrigatoriedade de exibição tenha criado um espaço para a maior inserção de obras nacionais, o decreto-lei no 21.240, que, em abril de 1932, determinou a obrigatoriedade de exibição não interrompeu o sistema das distribuidoras estrangeiras, que impunham aos exibidores a compra de pacotes com mais de cinquenta filmes, deixando pouco espaço para a manutenção dos filmes brasileiros em cartaz (SIMIS, 2008).

Simis (2008) aponta que neste momento, o Estado atribuía valor à atividade cinematográfica mais pelo seu potencial educativo, cultural e formador de opiniões do que pelo seu potencial industrial - gerador de empregos e renda; propriamente dito. Neste contexto, e após terem sido avaliados aspectos educativos e o potencial de captura e armazenamento da riqueza cultural, o cinema foi considerado atividade estratégica para o país e, em 1937, mediante decreto de Getúlio Vargas, foi criado o Instituto 
Nacional do Cinema Educativo ( $\operatorname{INCE}^{15}$ ), primeiro órgão público que apoiava a produção e divulgação de obras nacionais para fins educativos.

Entre o período democrático vivido pelo país, de 1945 a 1964; a cinematografia nacional conheceu um momento de esplendor com os movimentos da iniciativa privada. Embora tenham encontrado a falência precoce, as experiências privadas das chanchadas e a Companhia Cinematográfica Vera Cruz foram de enorme importância para a cinematografia nacional. O imenso sucesso vivido pelas chanchadas tornou evidente a existência de um mercado interno para as obras cinematográficas nacionais, notadamente entre as classes menos favorecidas, além de ter gerado um impacto em termos de geração de postos de trabalho e renda significativos.

A Companhia Cinematográfica Vera Cruz por sua vez, marcou época com a sua ambição de erguer uma indústria de cinema nacional equiparável à Hollywood e com o impacto causado na classe de cinema nacional e internacional por obras que tornaram clara a viabilidade da cinematografia brasileira. $O$ sonho de uma indústria cinematográfica forte e sofisticada, no entanto, durou poucos anos. Já no ano de 1954, a Companhia Vera Cruz apresentava sinais de declínio. Os motivos da decadência precoce da Companhia foram a não existência de um sistema de distribuição próprio distribuidores e exibidores internacionais tais como a Colúmbia e Universal ficavam com mais de $60 \%$ da arrecadação; conjugada à concorrência desigual com os filmes estrangeiros que ingressavam no país e à dificuldade de inserir o cinema brasileiro no competitivo mercado internacional. Desta forma, apesar de o sucesso de público e artístico experimentado pela Companhia Vera Cruz, o seu fracasso precoce tornou flagrante a limitação na comercialização das obras nacionais bem como evidenciou a impossibilidade de sobrevivência em uma estrutura que não remunera adequadamente a produção (JORGE, 2004).

Além do declínio dos movimentos privados, outros fatores contribuíram para agravar o cenário da cinematografia brasileira. Conforme destaca Mattos (2002), nos anos 60, a popularização dos aparelhos televisores, fortalecida e facilitada pelo apoio do regime militar e pelo barateamento dos custos dos aparelhos, já atingira um nível

15 Com a publicação da Lei 378 em 13 de janeiro de 1937, foi criado o INCE, primeiro órgão oficial do governo voltado para a atividade cinematográfica nacional de cunho educativo. De acordo com o Artigo 40 da Lei: "Fica criado o Instituto Nacional de Cinema Educativo, destinado a promover e orientar a utilização da cinematografia, especialmente como processo auxiliar do ensino, e ainda como meio de educação popular em geral". 
significativo e o mercado de cinema começava a ser severamente afetado pelo novo marco do entretenimento doméstico. Além disso, a aquisição e exibição de conteúdo estrangeiro pelas companhias de televisão - os quais eram comercializados a preços mais baixos que o conteúdo nacional, acabou por agravar ainda mais o ambiente de concorrência no qual o cinema brasileiro estava inserido.

Diferentemente do observado na maioria dos países, o Governo brasileiro não se estruturou e não se posicionou adequadamente após o aparecimento e afirmação da televisão. Ao não criar uma legislação que fomentasse a integração da atividade cinematográfica e os novos elos surgidos após o advento da indústria audiovisual, o Governo brasileiro acabou permitindo que cinema e televisão se bifurcassem em atividades isoladas, não provocando a criação de sinergias entre estas atividades e não permitindo que a produção de filmes tivesse seu ciclo de vida prolongado nas novas mídias (MATTOS, 2002).

\subsection{A era Embrafilme}

Com o acirramento do regime militar e aumento do rigor político - notadamente através da introdução de práticas de censura com o Decreto AI-5, em 1968; a vertente crítica de alguns movimentos artísticos internos, em particular do Cinema Novo ${ }^{16}$, foi sendo desestruturada e perdendo força. Por outro lado, sob o ponto de vista da atividade industrial, foi durante a ditadura que foram elaboradas e instauradas as políticas que possibilitaram à cinematografia brasileira atingir o maior patamar de participação no mercado interno de toda a história do cinema nacional (BERNARDET, 2001).

Neste contexto, o movimento mais representativo no sentido de favorecer a indústria cinematográfica nacional foi a criação, em 1966, do Instituto Nacional do Cinema (INC), autarquia federal cujo objetivo era centralizar a gestão da atividade de cinema nacional.

A criação do INC previa uma participação mais ativa do Estado no setor cinematográfico nacional. Por um lado a criação do INC não agradou a alguns representantes da classe cinematográfica por significar uma pulverização da

16 O movimento Cinema Novo foi iniciado na década de 1950 com o intuito de refletir nas obras cinematográficas a realidade brasileira. Sem adotar a estrutura de custos elevados das companhias privadas paulistas e contrário à alienação cultural refletida nas chanchadas, o Cinema Novo conquistou inúmeras premiações internacionais e chamou a atenção de pesquisadores nacionais e estrangeiros do ramo das artes e do cinema para a produção cinematográfica brasileira. 
participação dos diferentes setores na condução da atividade. Por outro lado, conforme assinala Simis (2008), neste momento surgiu uma nova mentalidade da cinematografia brasileira, onde sindicatos e associações do setor cinematográfico reconheceram a impossibilidade do cinema nacional competir com a produção estrangeira e que a intervenção estatal era vital para garantir a inserção de filmes nacionais nos circuitos de exibição (SIMIS, 2008).

A tabela abaixo descreve as principais contribuições do INC para a indústria cinematográfica nacional.

Tabela 1: Principais ações do INC

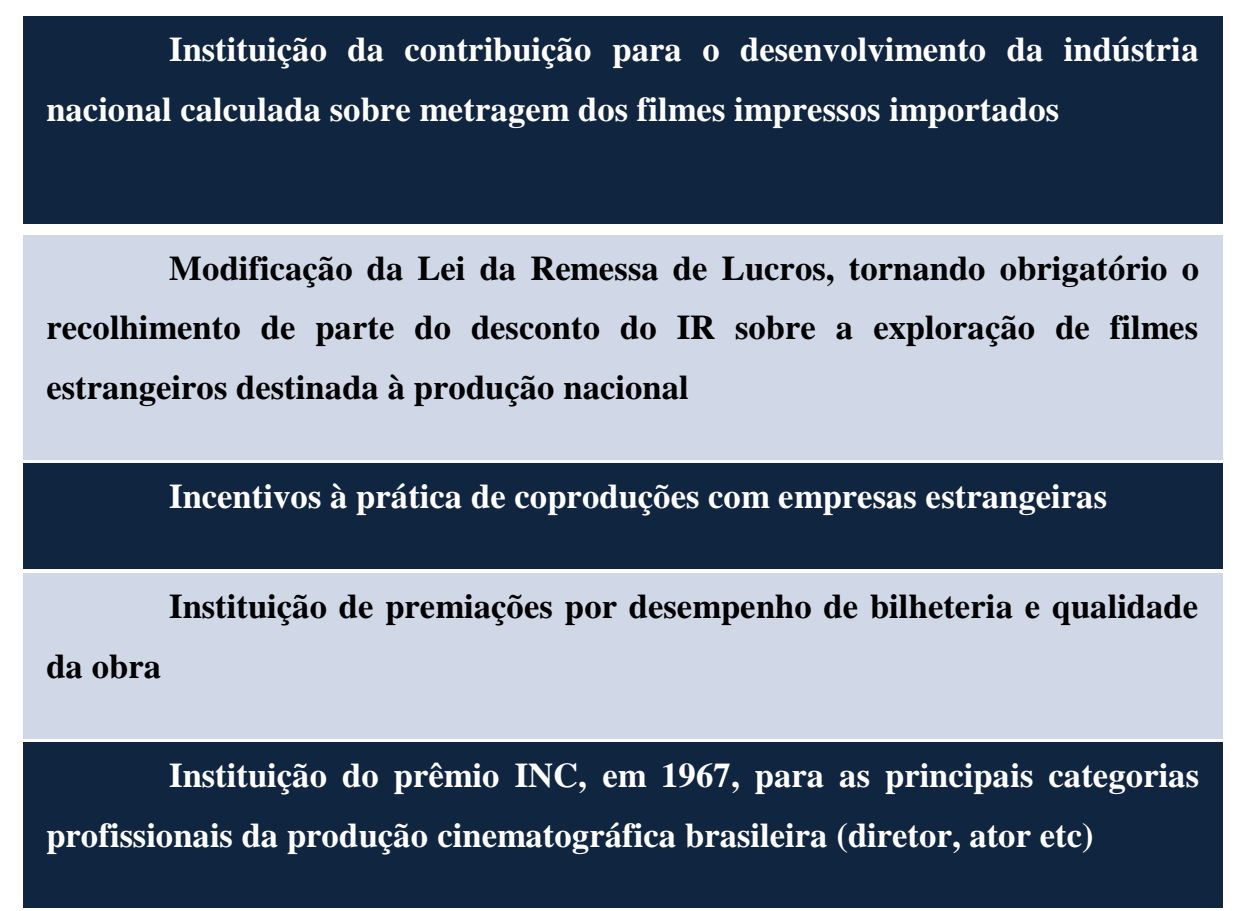

Fonte: Elaboração própria a partir de MINC, 2003.

Apesar da importância da atuação do INC e consequente ampliação da participação do cinema nacional nos circuitos de exibição, o principal marco intervencionista do Estado na trajetória da consolidação da indústria cinematográfica nacional foi a criação, no ano de 1969, da Empresa Brasileira de Filmes S.A. (Embrafilme). A atuação da Embrafilme determinou as bases da estrutura de competição da cinematografia nacional nas salas de exibição até a sua extinção, em 1990.

Criada pelo Decreto $\mathrm{n}^{\mathrm{o}} 862$ pela junta de ministros militares no poder, a Embrafilme era uma empresa de economia mista, que tinha por objetivos principais a promoção e distribuição de filmes nacionais no exterior. 
Se em um primeiro momento a atuação da empresa se restringia à promoção dos filmes nacionais fora do país, na década de 1970, após a extinção do Instituto Nacional de Cinema (INC), as atribuições da Embrafilme foram ampliadas e sua atuação passou a abarcar a produção, financiamento, promoção, distribuição e premiações do cinema nacional (AMANCIO, 2008).

A política industrial da Embrafilme gerou resultados positivos para a indústria cinematográfica brasileira. Tais resultados tornam-se evidentes quando se observa que, entre os anos de 1974 e 1978, os filmes nacionais assistiram a um aumento de mais de 100\% de público. Após a criação da distribuidora Embrafilme, um número maior de filmes nacionais passou a atingir o elo exibidor da indústria e a média anual do período 1975-1985 alcançou o marco de 88 filmes lançados por ano (MARQUES, 2009). Tal fato possibilitou que o filme nacional atingisse, já a partir de 1976, um patamar superior a 20\% de market share. Na Figura 6, segue um gráfico com a evolução do market share do filme nacional durante os anos de 1971 e 1980.

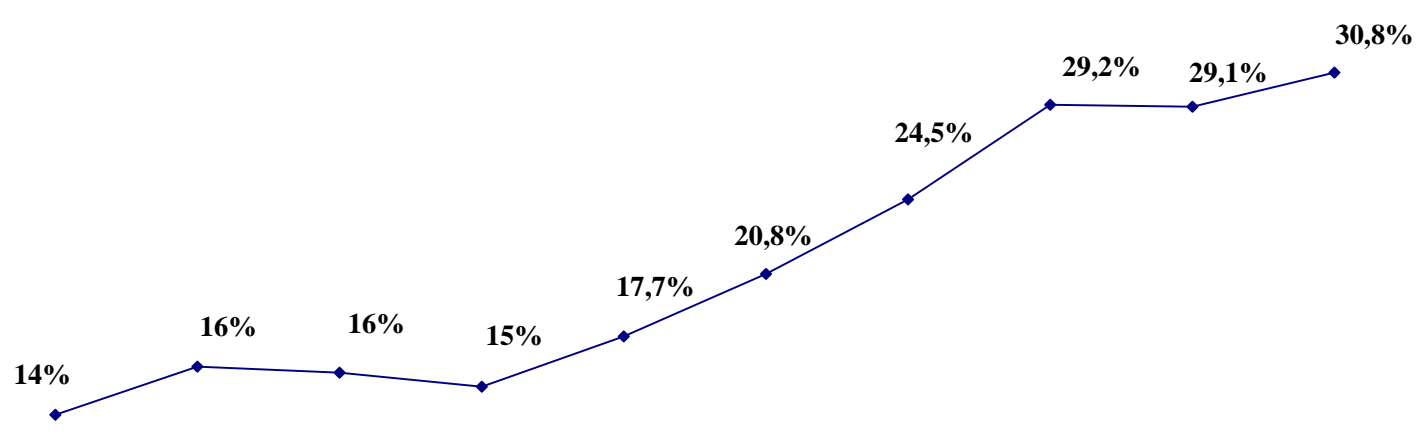

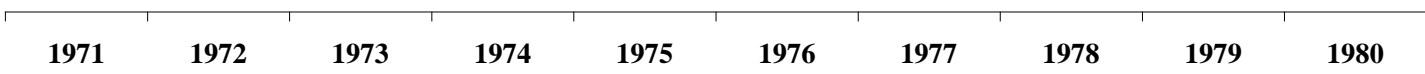

Figura 6: Market share do filme nacional 1971 - 1980

Fonte: MARQUES (2009)

Dentro deste contexto favorável de desenvolvimento da atividade, um clima otimista apontava, segundo Amancio (2008), para a consolidação industrial definitiva da indústria cinematográfica brasileira e para a obtenção de sua independência econômica. Almeida e Butcher (2003) destacam que a Embrafilme ocupou a liderança 
do market share nacional de distribuição por três anos (1978, 1979 e 1981), superando a atuação das majors.

O início da década de 1970 marcou a fase áurea da relação industrial do cinema nacional intermediada pela atuação do Estado e os primeiros revezes desta atuação só seriam sentidos no início da década de 1980.

A grave crise econômica que se instalou no país no final da década de 1970 interrompeu e desfragmentou o percurso de crescimento da atividade cinematográfica nacional. Com o Estado imerso em dificuldades econômicas, a indústria de cinema nacional assiste, neste momento, a um forte retrocesso e a utopia da sustentabilidade e independência da atividade perde espaço para uma nova realidade (AMANCIO, 2008).

Denunciada por uma campanha difamatória na imprensa, a Embrafilme enfrenta nos anos 1980 uma forte crise econômica e de legitimidade, resultado de denúncias de esquemas de distribuição de cargos e corrupção. Conjugado a estes fatores, o aumento vertiginoso da inflação transformou a questão orçamentária dos filmes em um problema grave, onde reajustes se faziam necessários em uma frequência desconfortável (MATTA, 2008).

Além destes fatores, ao longo da década de 1980, o mercado das salas de exibição assistiu a uma grave crise decorrente do aparecimento de novas estratégias de lançamento das majors (baseadas nos lançamentos mundiais dos blockbusters adaptados ao novo conceito de salas de exibição, o multiplex), e no acirramento competitivo das mídias de exibição domésticas o que só agravou a situação do cinema nacional. É importante ressaltar que o novo conceito de exibição, o multiplex, demandava um padrão tecnológico tanto de imagem como de som que não era acessível à maior parte das obras nacionais, o que se revelou como mais um entrave para o produto fílmico brasileiro.

No ano de 1990, em pleno processo de retomada da democracia, o então presidente eleito, Fernando Collor de Mello, em sua tendência privatista, declara sumariamente a extinção da Embrafilme e de toda a estrutura governamental que sustentava a produção e a comercialização do filme brasileiro no mercado interno das salas de exibição. Não foram sequer preservados os mecanismos de atualização e controle estatístico da atividade mantidos até então pelo Estado. 
Desta forma, de um momento de grande euforia sustentada por resultados promissores, a indústria cinematográfica brasileira retorna a uma posição de extrema fragilidade e incerteza. A este respeito, Amancio (2008) conclui:

"De uma situação de estabelecimento confortável frente ao mercado o cinema reduziu-se novamente a uma atividade periférica, recomeçando do zero. A produção nacional, que atingira nos picos dos anos 1970 mais de 100 filmes por ano, com uma ocupação de mercado da faixa de um terço, vai voltar a níveis insignificantes, e nesse vácuo permitir a reconquista desse terreno pelo cinema americano. $\mathrm{O}$ cinema brasileiro perdeu suas agências financiadoras, sua capacidade de produção e de distribuição e finalmente seu público, embora isto se tenha dado também por conta da modernização tecnológica [...] que mudou radicalmente o panorama do mercado de cinema.” (p. 181).

Embora as políticas de intervenção estatal tenham encontrado êxito durante a era Embrafilme e possibilitado que o cinema brasileiro atingisse uma posição representativa no mercado interno de exibição até os anos 1980, uma análise mais atenta do modelo adotado por essas políticas e a comparação com a estrutura e contexto gerais da indústria cinematográfica teriam evidenciado algumas inconsistências e a impossibilidade de um percurso duradouro e sustentável (MATTA, 2008).

Quando já nos anos cinquenta e sessenta, a indústria cinematográfica tornou-se, tal qual a televisão, o vídeo e futuramente as novas mídias visuais, parte componente da mais ampla e abrangente indústria do audiovisual, toda e qualquer política estatal que objetivasse o desenvolvimento consistente e perene da sua indústria cinematográfica nacional deveria necessariamente fundamentar-se na convergência dos elos componentes desta nova indústria.

A observância da conjuntura na qual o mercado cinematográfico norteamericano estava inserido no pós II Guerra Mundial permitiria a percepção de que a popularização da televisão gerou uma crise estrutural no mercado de cinema daquele país, resultando em grande diminuição do parque exibidor e que este efeito mais cedo ou mais tarde seria reproduzido no Brasil.

De acordo com Matta (2008), as políticas governamentais que visavam o desenvolvimento da indústria audiovisual no Brasil incorreram no grave erro estratégico 
de não terem criado instrumentos legais que proporcionassem a convergência entre as indústrias cinematográfica e televisiva, integrando a produção nos diferentes suportes e direcionando a participação da mídia televisiva na produção cinematográfica, tal qual ocorreu em alguns países, notadamente os EUA.

Foram criadas políticas de desenvolvimento para as indústrias cinematográfica e televisiva que seguiam lógicas isoladas, ao invés de uma política que favorecesse o desenvolvimento integrado da indústria audiovisual nacional. A televisão brasileira, contando com o apoio governamental e respaldada em uma estrutura favorável, desenvolveu-se com notória velocidade e de forma concentrada, com destaque para o grupo econômico que assume a posição líder do mercado televisivo até os dias atuais, as organizações Globo (ALMEIDA; BUTCHER, 2003).

\subsection{A Retomada}

Os anos que sucederam a extinção da Embrafilme e de outros órgãos públicos ligados à cultura foram marcados por uma reestruturação da relação entre o Estado brasileiro e a atividade cultural como um todo. A política cultural esboçada no governo de Fernando Collor de Mello e consolidada nos mandatos de Fernando Henrique Cardoso representou um sintoma de redefinição do papel desempenhado pelo Estado brasileiro resultante da entrada do país na era da globalização e do avanço acelerado da tecnologia que remodelou a dinâmica da cultura em todo o mundo.

Em contraposição ao papel desempenhado pelo Estado nas décadas anteriores mais interventor e indutor direto do desenvolvimento do setor cinematográfico; ao Estado caberia agora a função de regulador e articulador (MARQUES, 2009). Como decorrência desta reestruturação, na década de 1990, os governos focaram sua atuação no fomento indireto, lançando mão do mecenato corporativo como catalisador de recursos a serem investidos no setor cinematográfico (ALMEIDA; BUTCHER, 2003).

A nova estratégia de fomento à atividade cinematográfica focada no mecenato privado por meio da Lei Rouanet e da Lei do Audiovisual redefiniu a atuação do Estado brasileiro, através da adoção de uma postura neoliberal no setor cultural baseada nas políticas de incentivo à captação de recursos advindos da renúncia fiscal (ARRUDA, 2003).

O setor cultural bem como os agentes culturais, responsáveis pela captação de recursos, beneficiaram-se imensamente das políticas de incentivo indireto, recebendo 
recursos em proporção nunca antes vista. Além disso, a iniciativa privada encontrou nas leis de incentivo à cultura um canal inequívoco de valorização de sua imagem e de propaganda indireta de seus produtos (MARQUES, 2009). Aqui cabe ressaltar que a conjuntura econômica marcada pelo êxito na estabilidade monetária foi de fundamental importância para reinserir a atividade cinematográfica em uma trajetória de expansão da produção.

As primeiras medidas no sentido de enquadrar a atividade cinematográfica foram adotadas ainda sob gestão do governo Collor, quando o embaixador Sergio Rouanet assume o cargo de secretário de Cultura e lança, em 1991, o Programa Nacional de Apoio à Cultura (PRONAC), por meio da Lei 8.313/91, popularizada como Lei Rouanet.

O PRONAC disponibilizou três novos instrumentos de financiamento à indústria cinematográfica brasileira: o Fundo Nacional de Cultura (FNC), os Fundos de Investimentos Culturais e Artísticos (FICARTs) e o mecenato corporativo. Através do FNC, o Estado poderia apoiar diretamente $80 \%$ do orçamento de projetos culturais através de empréstimos. Os FICARTs consistiam em fundos de investimento que permitiam o abatimento integral do investimento realizado em projetos culturais de imposto de renda, caso estes apresentassem prejuízo aos seus cotistas. Caso os projetos gerassem lucro, os investidores deveriam ser taxados; caso contrário, o Estado se comprometia em arcar com todo o prejuízo. O mecenato corporativo, por sua vez, determinava que os contribuintes (pessoas físicas ou jurídicas) poderiam ter parte ou totalidade de investimentos em projetos culturais abatidos de seu imposto de renda.

Dos três mecanismos disponibilizados pelo PRONAC, o mecenato corporativo foi o que gerou maiores resultados. Conforme aponta SARKOVAS (2005, p. 22), o FNC não teve êxito por não ter sido "operado por regras primárias de um fundo público tais como transparência de critérios, acessibilidade paritária e primazia do mérito público", e os FICARTs, devido às maiores vantagens oferecidas pelo mecenato privado.

A classe cinematográfica avaliou positivamente a Lei Rouanet, porém a julgou insuficiente para a indústria do cinema no Brasil. Além disso, a gestão de Rouanet não foi capaz de estruturar a política audiovisual de tal modo que incluísse todos os segmentos desta indústria, notadamente as emissoras de TV aberta, que ficaram 
excluídas da exibição compulsória de filmes brasileiros em sua grade. Outra limitação da gestão de Rouanet foi a priorização da produção cinematográfica, em detrimento aos demais elos da cadeia produtiva de conteúdo audiovisual, restringindo a integração e comercialização dos produtos finais em todos os suportes (MARQUES, 2009).

4.4 Programas e mecanismos de fomento ao setor cinematográfico brasileiro na Retomada

\subsubsection{ANCINE}

Sob o ponto de vista regulatório, a indústria cinematográfica brasileira assistiu a mais um passo, com a criação, em 2001 da Agência Nacional de Cinema (ANCINE). Criada como autarquia especial pela Medida Provisória $n^{\circ} 2.228-1$, que definiu os princípios gerais da política nacional de cinema do governo do Presidente Fernando Henrique Cardoso, a ANCINE atua na regulação, fiscalização e fomento das atividades cinematográficas e audiovisuais (MARQUES, 2009).

\section{Tabela 2: Objetivos da ANCINE}

I - promover a cultura nacional e a língua portuguesa mediante o estímulo ao desenvolvimento da indústria cinematográfica e videofonográfica nacional em sua área de atuação;

II - promover a integração programática, econômica e financeira de atividades govemamentais relacionadas à indústria cinematográfica e videofonográfica;

III - aumentar a competitividade da indústria cinematográfica e videofonográfica nacional por meio do fomento à produção, à distribuição e à exibição nos diversos segmentos de mercado;

IV - promover a autossustentabilidade da indústria cinematográfica nacional visando o aumento da produção e da exibição das obras cinematográficas brasileiras;

V - promover a articulação dos vários elos da cadeia produtiva da indústria cinematográfica nacional;

VI - estimular a diversificação da produção cinematográfica e videofonográfica nacional e o fortalecimento da produção independente e das produções regionais com vistas ao incremento de sua oferta e à melhoria permanente de seus padrões de qualidade;

VII - estimular a universalização do acesso às obras cinematográficas e videofonográficas, em especial as nacionais;

VIII - garantir a participação diversificada de obras cinematográficas e videofonográficas estrangeiras no mercado brasileiro;

IX - garantir a participação das obras cinematográficas e videofonográficas de produção nacional em todos os segmentos do mercado interno e estimulá-la no mercado externo;

$\mathrm{X}$ - estimular a capacitação dos recursos humanos e o desenvolvimento tecnológico da indústria cinematográfica e videofonográfica nacional;

$\mathrm{XI}$ - zelar pelo respeito ao direito autoral sobre obras audiovisuais nacionais e estrangeiras.

Fonte: Elaboração própria a partir de ANCINE (2012) 
Através de articulações políticas foi aprovada uma legislação específica para o setor audiovisual, que culminou com criação, em 1993, da Lei 8.685/93, ou Lei do Audiovisual. Os principais instrumentos de financiamento disponibilizados pela nova lei constavam nos artigos $1^{\circ}$ e $3^{\circ}$.

\subsubsection{Lei do Audiovisual}

$\mathrm{O}$ artigo $1^{\circ}$ da Lei do Audiovisual determinava que contribuintes (pessoas físicas ou jurídicas) poderiam abater de seu imposto de renda o valor investido em projetos cinematográficos, respeitada a alíquota de dedução. Ao investir em um projeto de filme, o contribuinte virava acionista do filme através da aquisição de Certificados de Investimento Audiovisual $^{17}$, que garantiam a obtenção de lucro caso o filme tivesse êxito de bilheteria. Sob a ótica das empresas, o investimento era altamente vantajoso, na medida em que além de permitir a dedução do valor investido do imposto de renda e a divulgação de sua marca junto ao público de cinema, a Lei do Audiovisual possibilitava a contabilização de $25 \%$ do investimento como despesa operacional, o que reduzia ainda mais o valor da base tributável.

Um esquema resumido do mecanismo proposto pelo artigo $1^{\circ}$ da Lei do Audiovisual é apresentado na Figura 7.

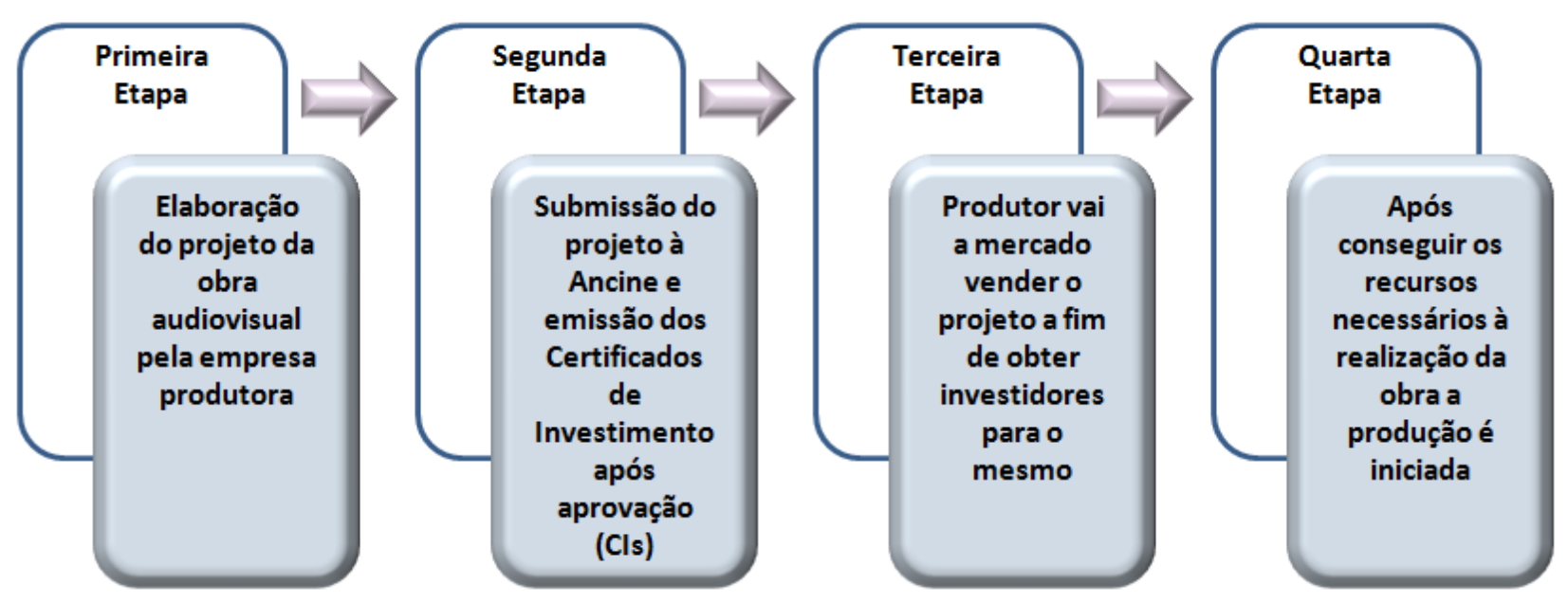

Figura 7: Mecanismo do artigo $1^{\circ}$ da Lei do Audiovisual

Fonte: Elaboração própria a partir de Michel (2011)

17 Os Certificados de Investimentos (CI) são valores mobiliários representativos de cotas de comercialização da obra. Cada cota garante ao investidor um percentual sobre as receitas auferidas pelo projeto em condições fixadas pela empresa emissora por ocasião do pedido de registro e expresso no Certificado de Investimento. (ZAVERUCHA, 1996, p.7) 
Outro artigo de grande impacto da Lei do Audiovisual foi o artigo $3^{\circ}$. Este artigo determinava que as empresas distribuidoras estrangeiras atuantes no país tinham a possibilidade de destinar para a coprodução de obras cinematográficas nacionais até $70 \%$ do imposto devido sobre a remessa de lucros e dividendos ao exterior, obtidos através da exploração comercial de filmes estrangeiros no país.

Um esquema resumido do funcionamento do artigo $3^{\circ}$ da Lei do Audiovisual é apresentado na Figura 8.

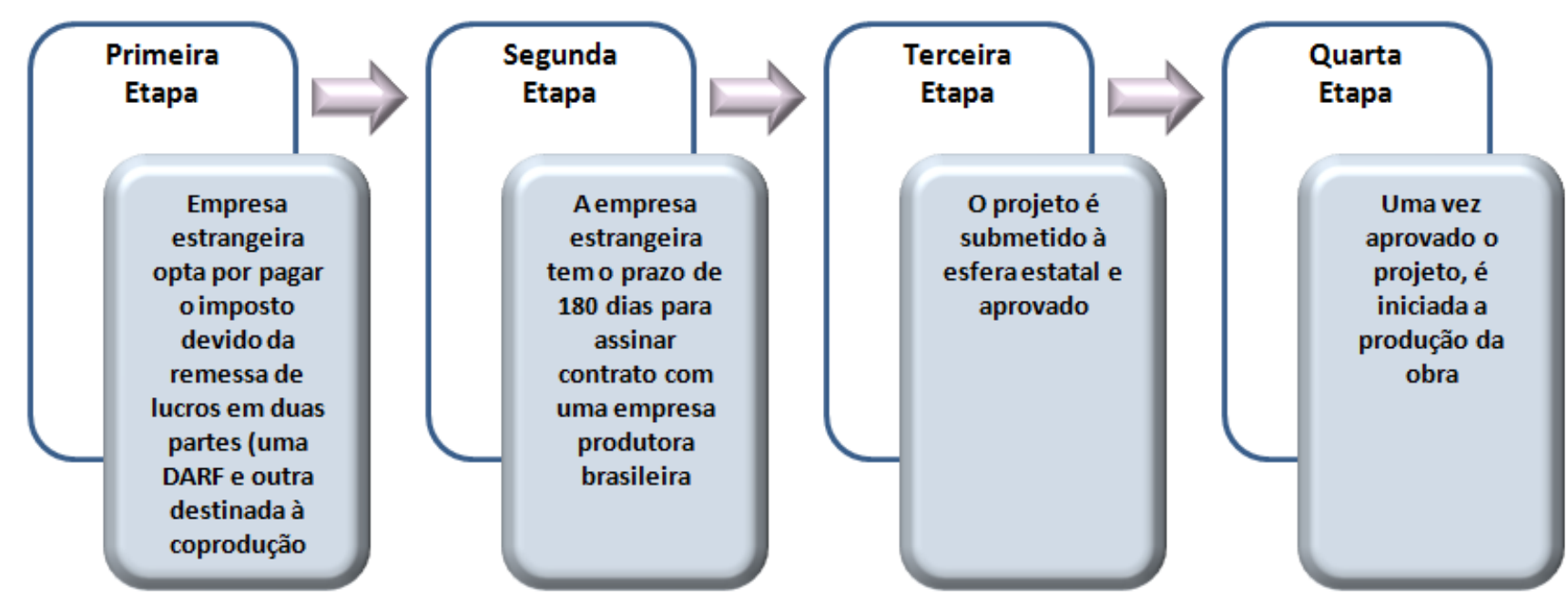

Figura 8: Mecanismo do artigo $3^{\circ}$ da Lei do Audiovisual

Fonte: Elaboração própria a partir de Michel (2011)

Por fim, o artigo $3^{\circ}$-A da Lei do Audiovisual, estende a possibilidade de investimento de parte do imposto de renda devido ao exterior na coprodução de obras nacionais às emissoras de televisão aberta e programadoras de TV por assinatura, com o objetivo de incentivar parcerias entre o setor cinematográfico e televisivo e ampliar o espaço ocupado pelos filmes nacionais nas grades de programação de TV.

Em decorrência do desconhecimento do funcionamento do mecanismo da Lei, e da baixa alíquota de dedução do imposto de renda, a Lei do Audiovisual não logrou, em um primeiro momento, em catalisar recursos suficientes para a produção de obras cinematográficas nacionais. Nos anos que sucederam a criação da Lei, no entanto, a disseminação do funcionamento do mecanismo juntamente ao aumento da alíquota (de $1 \%$ para 3\%) resultou na obtenção de montantes expressivos de recursos destinados à produção cultural, possibilitando a retomada da produção cinematográfica nacional e a conquista do público espectador pelo filme brasileiro (ALMEIDA; BUTCHER, 2003). 


\subsubsection{FUNCINES}

Além dos mecanismos baseados em incentivos fiscais, é relevante destacar a criação, a partir da Medida Provisória $\mathrm{n}^{\circ}$ 2.228-1 de 2001, dos Fundos de Financiamento da Indústria Cinematográfica Nacional (FUNCINES). O dispositivo dos FUNCINES permite a constituição de fundos que podem investir na produção cinematográfica e audiovisual brasileira ou em qualquer empreendimento associado à cadeia cinematográfica conforme exemplificado abaixo:

1. Aquisição de ações de empresas de infraestrutura, fornecedores, distribuidores, exibidores e produtores;

2. Projetos de construção, reforma e recuperação de salas de exibição;

3. Projetos de infraestrutura realizados por empresas brasileiras;

4. Produção de obras audiovisuais brasileiras;

5. Comercialização e distribuição de obras cinematográficas brasileiras.

Diferentemente de muitos fundos de investimento, os FUNCINES conferem aos seus investidores a possibilidade de dedução fiscal correspondente a $100 \%$ do valor investido até o limite de $3 \%$ do imposto de renda a pagar, no caso de pessoa jurídica, ou 6\%, no caso de pessoa física (BNDES, 2011).

Os fundos são administrados por instituições financeiras legalmente habilitadas pelo Banco Central do Brasil e representam mais uma alternativa de investimento para a indústria cinematográfica nacional (ANCINE, 2012).

A obra nacional de grande sucesso Divã (2009) foi integralmente produzida com recursos advindos de FUNCINES, tendo captado um total de $\mathrm{R} \$ 4.250 .000$ e atingido um público de quase dois milhões de expectadores, que geraram uma receita de $\mathrm{R} \$$ 16.492.461,00 (ANCINE, 2012).

Devido a sua natureza recente, os resultados dos FUNCINES ainda não permitem uma coleta de resultados representativa para a elaboração de uma análise da sua eficácia. A possibilidade de investimentos em todo o segmento da cadeia produtiva deve, conforme ressalta Michel (2011), auxiliar no desenvolvimento da indústria cinematográfica nacional, porém como as rentabilidades de fundos de investimento requerem um tempo para serem avaliadas, ainda não é possível fazer uma projeção da eficiência e durabilidade deste mecanismo. 


\subsubsection{Fundo Setorial do Audiovisual (FSA)}

O Fundo Setorial do Audiovisual (FSA) é um fundo de natureza contábil destinado ao desenvolvimento articulado de toda a cadeia produtiva da atividade audiovisual no Brasil. Criado em 2006 pela Lei $n^{\circ}$ 11.437, o FSA constitui uma modalidade específica do Fundo Nacional de Cultura (FNC).

Dentre os principais objetivos do FSA estão: o aumento da cooperação entre os agentes econômicos envolvidos na cadeia; a ampliação e diversificação da infraestrutura de serviços e de salas de exibição; o incentivo à pesquisa e inovação; o crescimento sustentado da participação de mercado do conteúdo nacional e o desenvolvimento de novos meios de difusão da produção audiovisual brasileira.

As ações de fomento do FSA são:

1. Apoio a projetos audiovisuais específicos;

2. Equalização de encargos financeiros incidentes nas operações de financiamento;

3. Investimentos em empresas e projetos; e

4. Financiamento ao setor audiovisual.

Os recursos empregados pelo FSA são oriundos de contribuições recolhidas pelos agentes do mercado, principalmente a Contribuição para o Desenvolvimento da Indústria Cinematográfica Nacional $\left(\mathrm{CONDECINE}^{18}\right)$ e do Fundo de Fiscalização das Telecomunicações (FISTEL ${ }^{19}$ ).

Um Comitê Gestor define as diretrizes e o plano anual de investimentos do FSA, acompanha a implementação das ações e avalia a cada ano os resultados alcançados. $\mathrm{O}$ Fundo tem ainda a Agência Nacional do Cinema (ANCINE) como Secretaria Executiva e conta com o BNDES como agente (BNDES, 2011).

18 A Contribuição para o Desenvolvimento da Indústria Cinematográfica Nacional (CONDECINE) terá por fato gerador a veiculação, a produção, o licenciamento e a distribuição de obras cinematográficas e videofonográficas com fins comerciais. A CONDECINE também incidirá sobre o pagamento, o crédito, o emprego, a remessa ou a entrega, aos produtores, distribuidores ou intermediários no exterior, de importâncias relativas a rendimento decorrente da exploração de obras cinematográficas e videofonográficas ou por sua aquisição ou importação, a preço fixo (MP No. 2228 DE 06 /09 /2001 Art. 32.).

${ }^{19}$ Fundo de natureza contábil, destinado a prover recursos para cobrir as despesas feitas pelo Governo Federal na execução da fiscalização dos serviços de telecomunicações, desenvolver os meios e aperfeiçoar a técnica necessária a essa execução. 


\subsubsection{PROCULT}

Criado no ano de 2006, o Programa para o Desenvolvimento da Economia da Cultura (PROCULT) dedicava-se, até 2009, unicamente à cadeia produtiva do audiovisual. A partir deste ano, o programa se expande, passando a fornecer suporte financeiro a diferentes segmentos da economia da cultura.

O PROCULT possui dotação orçamentária de $\mathrm{R} \$ 1,5$ bilhão e fornece apoio financeiro através de três subprogramas: BNDES PROCULT - Financiamento, BNDES PROCULT - Renda Variável e BNDES PROCULT - Não Reembolsável; visando atingir os seguintes objetivos:

1. Viabilizar o apoio ao desenvolvimento e fortalecimento da cadeia produtiva da economia da cultura no País;

2. Preservar a memória cultural nacional tangível e intangível;

3. Estimular a diversidade cultural brasileira;

4. Promover a descentralização da oferta de bens culturais;

5. Promover a inclusão social por meio da arte e da cultura.

A Tabela 3 abaixo apresenta a dotação orçamentária por subprograma do PROCULT:

Tabela 3: Dotação orçamentária PROCULT (por subprograma)

\begin{tabular}{|l|c|c|}
\hline \multicolumn{1}{|c}{ Subprograma } & $\begin{array}{c}\text { Limite total } \\
\text { (milhões de R\$) }\end{array}$ & $\begin{array}{c}\text { Limite anual } \\
\text { (milhões de R\$) }\end{array}$ \\
\hline BNDES Procult - Financiamento & $\mathbf{8 0 0}$ & $\mathbf{2 5 0}$ \\
\hline BNDES Procult - Renda Variável & 200 & 100 \\
\hline BNDES Procult - Não Reembolsável & $\mathbf{5 0 0}$ & 150 \\
\hline
\end{tabular}

Fonte: Elaboração própria a partir de BNDES (2011)

Conforme destaca Michel (2011), o apoio ao setor advindo do PROCULT foi positivo na medida em que criou uma alternativa de crédito além dos mecanismos de incentivos fiscais. Com novas alternativas, a indústria audiovisual reduz sua dependência vis à vis os instrumentos de renúncia para seu funcionamento e são gerados incentivos de desenvolvimento calcados em resultados financeiros, condição essencial para a construção de um percurso sustentável para o setor. 


\subsubsection{Cota de Tela}

Estabelecida em 2011 através do Decreto 7647/2011, a Cota de Tela determina o número de dias e a diversidade mínima de títulos brasileiros a serem exibidos nas salas de cinema do país a cada ano.

Adotada em diversos países com o intuito de promover o aumento da competitividade e a sustentabilidade da indústria cinematográfica nacional, o instrumento da Cota de Tela foi estabelecido pela primeira vez no Brasil na década de 1930 (ANCINE, 2012).

Em função do número de salas de exibição do complexo, os cinemas precisam cumprir uma Cota de Tela mínima entre 28 e 63 dias por sala e exibir no mínimo entre 3 e 14 filmes nacionais diferentes. Para complexos de 6 e 7 salas, a obrigação será de 63 dias por cada sala e no mínimo 8 e 9 títulos no complexo (ANCINE, 2012).

Embora seja uma ação protecionista, a cota de tela constitui importante instrumento de enfrentamento ao oligopólio norte americano nas salas de exibição, através da tentativa do Estado de inserir o filme brasileiro no mercado, gerando para o consumidor a opção do cinema nacional. Apesar de alguns filmes não necessitarem dessa política por já possuirem a capacidade de competir com filmes de Hollywood (os chamados blockbusters nacionais, tais como Tropa de Elite e Se eu Fosse Você), a maioria não possui o grau de competitividade exigido e a cota de tela é capaz de auxiliar o setor através da criação induzida de oferta (MICHEL, 2011).

\subsubsection{Lei da TV Paga}

Discutida por cinco anos no Congresso Nacional antes de entrar em vigor, em setembro de 2011, a Lei 12.485 (ou Lei da TV Paga) propõe remover barreiras à competição, valorizar a cultura brasileira e incentivar uma nova dinâmica para produção e circulação de conteúdos audiovisuais nacionais, possibilitando que um número maior de brasileiros tenha acesso a esses conteúdos.

Através da abertura do mercado a novos competidores, a Lei da TV Paga amplia a oferta do serviço e estimula a redução do preço final ao assinante, além de estabelecer a obrigatoriedade de inclusão de conteúdos nacionais nos canais de espaço 
qualificado $^{20}$, e de canais brasileiros dentro de cada pacote ofertado ao assinante (ANCINE, 2012).

A promulgação da Lei da TV Paga constitui o primeiro marco regulatório convergente para a atividade audiovisual no Brasil, ao unificar a regulamentação dos serviços de televisão por assinatura que estava dispersa sob diferentes comandos legais.

O objetivo da lei é criar as condições necessárias para a multiplicação de empreendimentos e a geração de riqueza interna, abrindo espaço para que o Brasil possa vir a se tornar um grande polo produtor audiovisual, a exemplo de outros países que se consolidaram como produtores de conteúdos e exportadores de formatos audiovisuais.

A Lei 12.485 abre oportunidades de crescimento para diferentes segmentos do mercado: para as produtoras, na medida em que será criada demanda por 1.070 horas anuais de conteúdos audiovisuais nacionais; para as programadoras brasileiras, uma vez que a lei induz o aumento da demanda por novos canais brasileiros de espaço qualificado; e para a programadoras estrangeiras, que terão uma proximidade maior do público brasileiro (ANCINE, 2012).

O início deste período que ficou conhecido como Retomada do Cinema Nacional pode ser expressa em alguns dados estatísticos. Entre os anos 1991 e 199413 filmes nacionais foram lançados; já entre os anos 1995 e 1998 este número se elevou a 81 filmes, dos quais cinco ultrapassaram a marca de um milhão de espectadores (ANCINE, 2012). Além disso, o movimento de retomada da atividade se expressou também no aumento do número de salas, conforme pode ser observado na Figura 9 abaixo.

20 Espaço total do canal de programação, excluindo-se conteúdos religiosos ou políticos, manifestações e eventos esportivos, concursos, publicidade, televendas, infomerciais, jogos eletrônicos, propaganda política obrigatória, conteúdo audiovisual veiculado em horário eleitoral gratuito, conteúdos jornalísticos e programas de auditório ancorados por apresentador. 


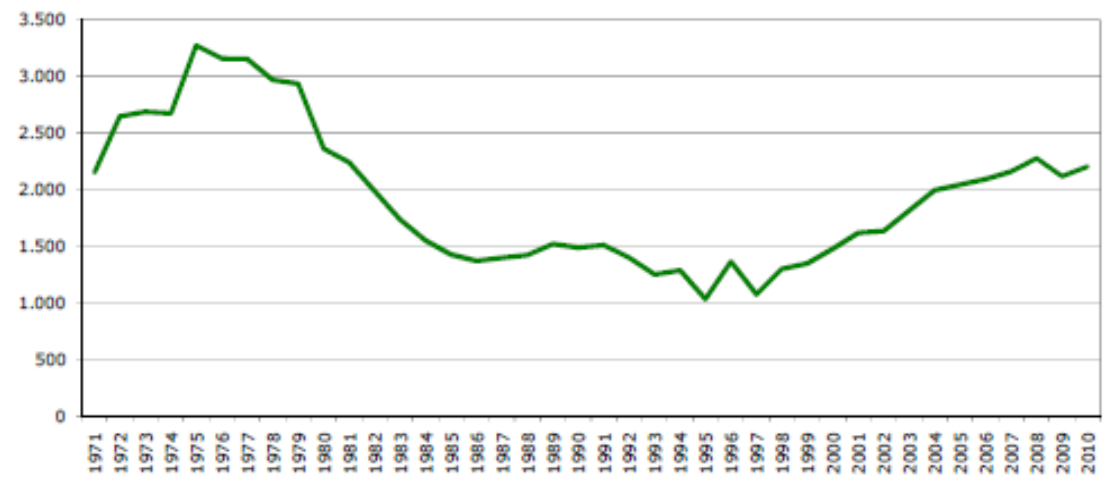

Figura 9: Evolução do número de salas no país 1971 - 2010

Fonte: ANCINE (2012)

O desempenho do público e renda dos filmes nacionais é retratado na Tabela 4 abaixo.

Tabela 4: Público e Renda de Filmes Nacionais por Ano (Todos gêneros)

\begin{tabular}{|c|c|}
\hline \multicolumn{2}{|c|}{ Público por Ano - Geral } \\
\hline Ano de Lançamento & Público \\
\hline 1995 & 3.278 .508 \\
1996 & 1.070 .852 \\
1997 & 3.750 .913 \\
1998 & 4.330 .557 \\
1999 & 6.092 .779 \\
2000 & 6.344 .669 \\
2001 & 7.948 .065 \\
2002 & 7.170 .334 \\
2003 & 22.291 .806 \\
2004 & 15.494 .873 \\
2005 & 10.178 .369 \\
2006 & 10.727 .571 \\
2007 & 9.112 .934 \\
2008 & 8.617 .003 \\
2009 & 17.249 .039 \\
\hline Total & $\mathbf{1 3 3 . 6 5 8 . 2 7 2}$ \\
\hline
\end{tabular}

\begin{tabular}{|c|c|}
\hline \multicolumn{2}{|c|}{ Renda por Ano - Geral } \\
\hline Ano de Lançamento & Renda (R\$) \\
\hline 1995 & $14.681 .088,00$ \\
1996 & $4.742 .154,00$ \\
1997 & $16.564 .437,00$ \\
1998 & $18.616 .704,00$ \\
1999 & $25.261 .991,00$ \\
2000 & $31.610 .071,00$ \\
2001 & $40.475 .909,00$ \\
2002 & $39.322 .601,00$ \\
2003 & $135.329 .180,58$ \\
2004 & $102.344 .654,00$ \\
2005 & $71.545 .402,50$ \\
2006 & $78.769 .170,00$ \\
2007 & $71.954 .656,00$ \\
2008 & $66.080 .770,46$ \\
2009 & $140.900 .986,55$ \\
\hline Total & $\mathbf{8 5 8 . 1 9 9 . 7 7 5 , 0 9}$ \\
\hline
\end{tabular}

Fonte: ANCINE (2012) 
4.5 Panorama dos elos da cadeia cinematográfica brasileira nos dias atuais

A presente seção ilustrará o posicionamento atual em termos de ocupação do mercado nacional dos três elos componentes da cadeia cinematográfica brasileira. Para um panorama mais amplo da situação socioeconômica do país e análise dos dados e valores das maiores bilheterias do cinema nacional sugere-se a consulta às Tabelas 5, 6 e 7 contidas no Apêndice do presente trabalho.

\subsubsection{Posicionamento do elo da Produção}

O Posicionamento elo da Produção no Brasil pode ser analisado nas Figuras 10 e 11, que apresentam a evolução do market share e do público do filme nacional desde 1995 até o ano de 2010.

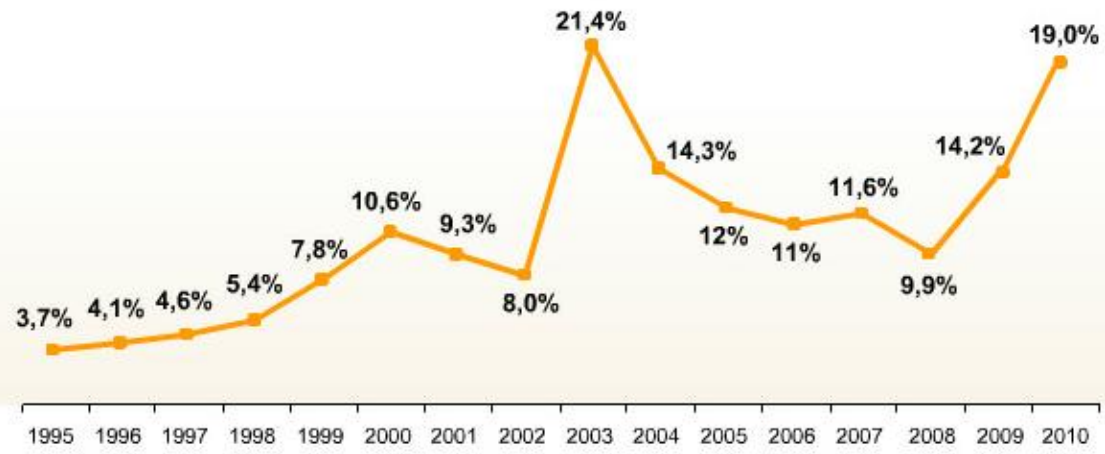

Figura 10: Evolução do market share do filme nacional 1995-2010

Fonte: FilmeB (2012)

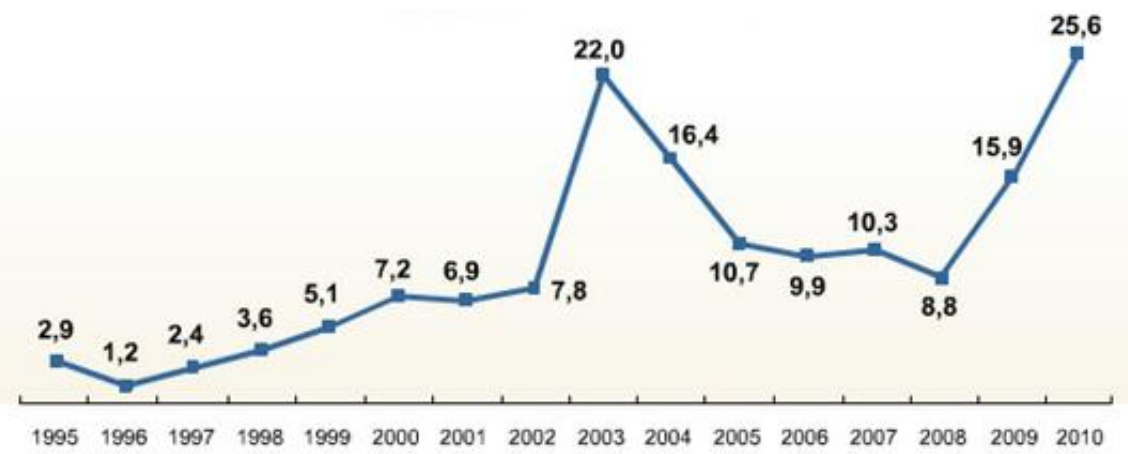

Figura 11: Evolução do público do filme nacional 1995-2010

Fonte: FilmeB (2012) 
A adoção de políticas culturais voltadas para a indústria audiovisual foi de fundamental importância para a retomada da produção de obras nacionais. O histórico do setor apresentado nas seções anteriores torna evidente que a participação do Estado é crucial para o seu funcionamento.

No Brasil, a Produção é o elo mais pulverizado em relação à quantidade de agentes econômicos atuando na atividade. Em 2010 cerca de 4.000 empresas produtoras de obras audiovisuais eram registradas na ANCINE, das quais 618 tinham projetos de obras em fase de captação de recursos pelas Leis de incentivo federal (ANCINE, 2012).

\subsubsection{Posicionamento do elo da Distribuição}

No Brasil observa-se o domínio, embora não absoluto, das distribuidoras internacionais (majors) no segmento de distribuição, notadamente ao analisarmos a carteira de distribuição de filmes estrangeiros. A Figura 12 abaixo mostra o posicionamento dos stakeholders ${ }^{21}$ do segmento da distribuição no ano de 2010 no tocante aos resultados obtidos em público e em renda (em reais).

\footnotetext{
${ }^{21}$ Pessoa ou grupo que pode afetar ou ser afetado pelo desempenho da organização (FREEMAN, 1984).
} 


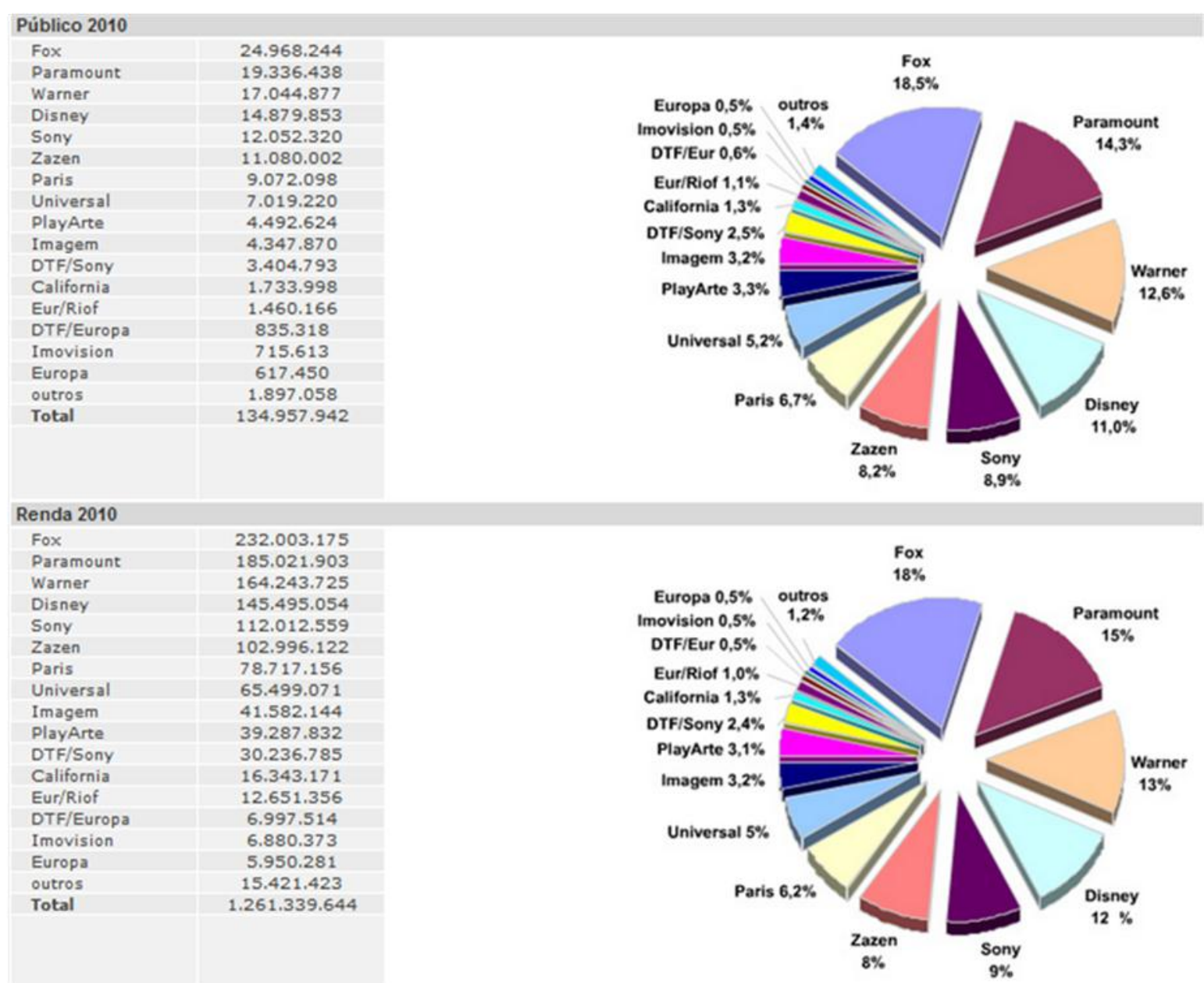

Figura 12: Market share das distribuidoras - Público e Renda

Fonte: FilmeB (Database Brasil 2011)

Ao restringirmos a análise aos filmes nacionais lançados no mesmo ano de 2010, observamos um pequeno acréscimo no market share dos stakeholders da distribuição nacional. A despeito disto, as majors permanecem com as maiores fatias do mercado do segmento, conforme pode ser observado na Figura 13 abaixo. 


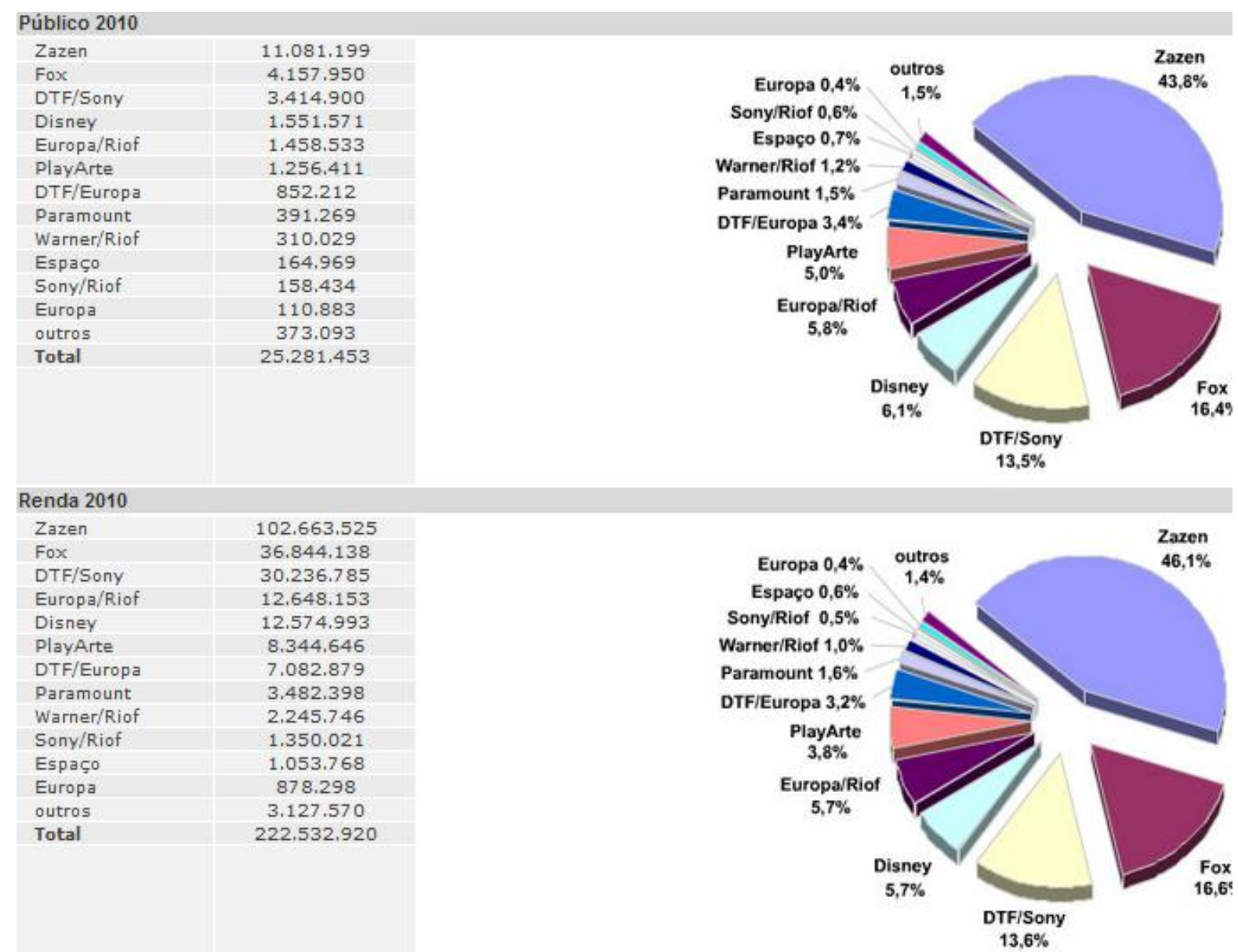

Figura 13: Market share das distribuidoras - Público e Renda filmes nacionais

Fonte: FilmeB (Database Brasil 2011)

Em termos de resultados da distribuição, o ano de 2010 foi espetacular, tendo registrado um público total de 134,3 milhões de espectadores e renda de R \$1,25 bilhão, com a exibição de 509 filmes, dos quais 303 lançamentos. Este constitui o maior público desde 1982, com um crescimento de $19 \%$ nas entradas e de $29 \%$ na renda comparado aos números do ano de 2009.

O aumento do público do cinema neste ano deveu-se em grande medida ao desempenho das produções nacionais, em particular, do filme Tropa de Elite 2, que representou, sozinho, $44 \%$ do público de filmes nacionais e $8 \%$ do público total das salas. Em 2010, o público do cinema nacional foi de aproximadamente 25 milhões de espectadores, seja 56\% acima do registrado em 2009. Com esta performance, a participação de público dos filmes brasileiros em 2010 foi de 19\%. Além de Tropa de Elite 2, as obras lançadas neste ano que encontraram o maior sucesso foram os filmes 
com temática espírita Nosso Lar e Chico Xavier, com mais de 7 milhões de espectadores (ANCINE, 2012).

\subsubsection{Posicionamento do elo da Exibição}

As figuras 14 e 15 apresentam, respectivamente, a geografia das salas de exibição no país e o mapa de distribuição dos complexos multiplex por unidade federativa no Brasil:

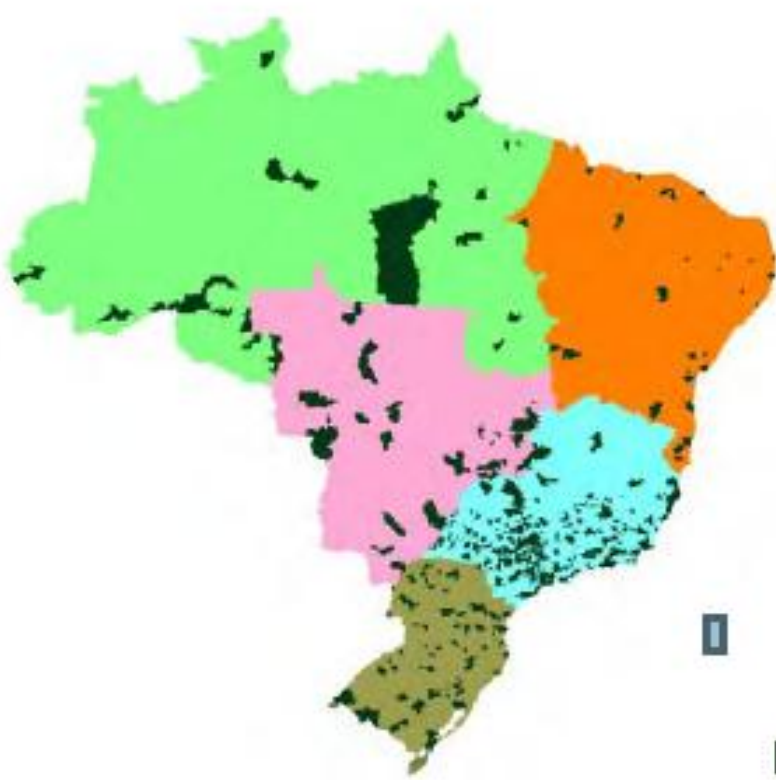

Cidades com cinema

Figura 14: Dispersão das salas de exibição no país

Fonte: IBGE (Censo 2010) ${ }^{22}$

${ }^{22}$ A região norte, em parte por sua baixa densidade demográfica e geografia peculiar, é a região com o menor número de salas. Estas se restringem basicamente às capitais dos estados. No mapa, destaca-se uma grande área com presença de salas de cinemas. Trata-se do município de Altamira, que possui 160 mil km², mas apenas uma sala para seus 105 mil habitantes. 


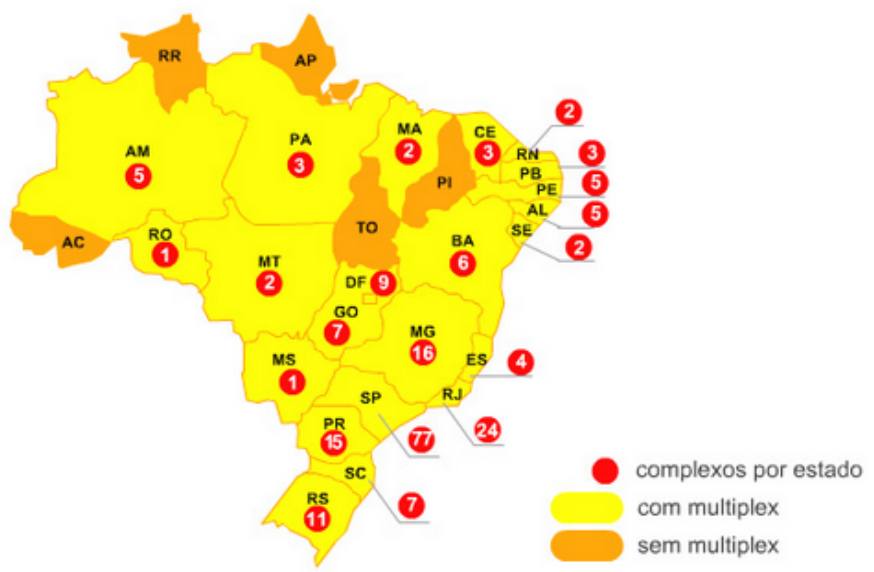

\begin{tabular}{|l|l|l|}
\hline $\begin{array}{l}\text { Total de cinemas multiplex por estado } \\
\text { UF }\end{array}$ & \multicolumn{1}{l|}{ total } & market share \\
\hline São Paulo & 77 & $37,4 \%$ \\
\hline Rio de Janeiro & 24 & $11,7 \%$ \\
\hline Minas Gerais & 16 & $7,8 \%$ \\
\hline Paraná & 15 & $7,3 \%$ \\
\hline Rio Grande do Sul & 11 & $5,3 \%$ \\
\hline Distrito Federal & 9 & $4,4 \%$ \\
\hline Goiás & 7 & $3,4 \%$ \\
\hline Santa Catarina & 7 & $3,4 \%$ \\
\hline Bahia & 6 & $2,9 \%$ \\
\hline Amazonas & 5 & $2,4 \%$ \\
\hline Pernambuco & 5 & $2,4 \%$ \\
\hline Espirito Santo & 4 & $1,9 \%$ \\
\hline Paraiba & 3 & $1,5 \%$ \\
\hline Ceará & 3 & $1,5 \%$ \\
\hline Pará & 3 & $1,5 \%$ \\
\hline Maranhão & 2 & $1,0 \%$ \\
\hline Mato Grosso & 2 & $1,0 \%$ \\
\hline Rio Grande do Norte & 2 & $1,0 \%$ \\
\hline Sergipe & 2 & $1,0 \%$ \\
\hline Alagoas & 1 & $0,5 \%$ \\
\hline Mato Grosso do Sul & 1 & $0,5 \%$ \\
\hline Rondonia & 1 & $0,5 \%$ \\
\hline Total & 206 & $100,0 \%$ \\
\hline
\end{tabular}

\begin{tabular}{|c|c|c|}
\hline \multicolumn{3}{|c|}{ Total de salas multiplex por estado } \\
\hline UF & total & market share \\
\hline São Paulo & 546 & $39,2 \%$ \\
\hline Rio de Janeiro & 159 & $11,4 \%$ \\
\hline Minas Gerais & 97 & $7,0 \%$ \\
\hline Paraná & 88 & $6,3 \%$ \\
\hline Distrito Federal & 66 & $4,7 \%$ \\
\hline Rio Grande do Sul & 65 & $4,7 \%$ \\
\hline Bahia & 46 & $3,3 \%$ \\
\hline Pernambuco & 41 & $2,9 \%$ \\
\hline Amazonas & 40 & $2,9 \%$ \\
\hline Goiás & 40 & $2,9 \%$ \\
\hline Santa Catarina & 40 & $2,9 \%$ \\
\hline Espirito Santo & 25 & $1,8 \%$ \\
\hline Ceará & 24 & $1,7 \%$ \\
\hline Pará & 19 & $1,4 \%$ \\
\hline Paraiba & 18 & $1,3 \%$ \\
\hline Maranhão & 16 & $1,1 \%$ \\
\hline Mato Grosso & 16 & $1,1 \%$ \\
\hline Rio Grande do Norte & 14 & $1,0 \%$ \\
\hline Sergipe & 14 & $1,0 \%$ \\
\hline Mato Grosso do Sul & 9 & $0,6 \%$ \\
\hline Alagoas & 5 & $0,4 \%$ \\
\hline Rondonia & 5 & $0,4 \%$ \\
\hline Total & 1.393 & $100,0 \%$ \\
\hline
\end{tabular}

Figura 15: Mapa de distribuição dos complexos multiplex no Brasil

Fonte: FilmeB (2012)

No ano de 2010, o Brasil mantinha 2.206 salas, distribuídas entre os 662 cinemas os quais eram operados por aproximadamente 400 empresas.

As duas maiores empresas de exibição do país, a multinacional norte-americana Cinemark e o Grupo Severiano Ribeiro, de capital nacional, respondem por cerca da metade da receita gerada pelas salas de cinema no país tendo superado a marca de $\mathrm{R} \$ 1,2$ bilhão em 2010 (ANCINE, 2012).

4.6 Análise dos resultados dos programas e mecanismos da Retomada

Se por um lado no período da Retomada a indústria cinematográfica brasileira viveu um momento de renascimento, as políticas que possibilitaram esta renovação não foram isentadas de críticas que apontavam suas limitações. Uma das consequências das modificações na Lei do Audiovisual adotada no governo FHC foi o incentivo às produções de grandes orçamentos, o que levantou o debate dentro do setor 
cinematográfico quanto à viabilidade de grandes produções em um mercado liderado pela cinematografia norte-americana - devido à elevação da desvantagem competitiva da cinematografia nacional (MARQUES, 2009).

A atuação do Estado como mero repassador indireto de recursos públicos através dos instrumentos de renúncia fiscal; se confrontou com a incapacidade de elaboração de uma política mais abrangente que fosse capaz de incorporar à sua dinâmica os demais elos da indústria audiovisual, enquadrando notadamente o setor televisivo e publicitário.

Tal qual se observa nos demais países, a indústria do cinema depende cada vez mais do alinhamento e proximidade com os demais segmentos audiovisuais (AMANCIO, 2008). No Brasil, a integração entre cinema e televisão ocorreu de maneira superficial e insuficiente, calcada apenas na transposição da estética televisiva e publicitária nos filmes, como estratégia encontrada por alguns cineastas para aproximar suas obras do público. Até recentemente, nenhum mecanismo de obrigatoriedade de exibição dos produtos da indústria cinematográfica nos suportes televisivos havia sido criado e tampouco foram determinadas leis que gerassem mecanismos de financiamento para o cinema brasileiro a partir da contribuição das emissoras de TV (MARQUES, 2009).

A criação, em 1997 do braço cinematográfico da principal rede de televisão nacional, a Globo Filmes, gerou euforia entre alguns agentes do setor cinematográfico brasileiro, esperançosos da atuação desta como distribuidora nacional que adquiriria e atuaria também em prol das produtoras independentes. No entanto, rapidamente ficou claro que a Globo focaria sua atuação na distribuição de filmes de produção in house, aproveitando-se da utilização da já existente infraestrutura dos estúdios televisivos e do seu star system (aproveitamento do valor e influência midiáticos de alguns atores como estratégia comercial e mitigadora de risco de frequentação), agravando a estrutura competitiva entre as produtoras nacionais (ALMEIDA; BUTCHER, 2003).

Acerca da importância da atuação da Globo Filmes para a cinematografia nacioanal, Matta (2008) assinala:

"As produções que trazem o selo da Globo Filmes têm obtido destacado desempenho de bilheteria, sendo fundamentais para o incremento da competitividade do cinema nacional, a ponto de 13 dos 
20 maiores sucessos de público do cinema nacional, entre 1994 e 2003, terem tido participação direta ou algum tipo de apoio desta produtora. O sucesso dessas produções tem relação direta com o fato de suas campanhas de lançamento terem obtido significativo espaço de divulgação na Rede Globo”. (p. 12)

Nos dois mandatos do Presidente FHC a indústria cinematográfica brasileira assistiu à solidificação da utilização das leis de incentivos indiretos como mecanismos de financiamento (funding) da atividade cinematográfica. Apesar de ainda se encontrar em um patamar de atividade inferior ao observado no passado, o cinema nacional retomou o ciclo de produções e reencontrou seu público. A produção foi diversificada e obteve reconhecimento internacional através de indicações e participação em disputas de prêmios relevantes do cinema mundial (ALMEIDA; BUTCHER, 2003).

No entanto, alguns pontos devem ser ressaltados. As alterações na Lei do Audiovisual retiraram do produtor a responsabilidade pelo desempenho mercadológico das obras produzidas, na medida em que a contrapartida das empresas investidoras nos projetos foi diminuída ao mesmo tempo em que foi permitida a remuneração a priori das produtoras através da taxa de administração dos recursos captados (10\% do orçamento da obra). É relevante destacar que isto segue na direção oposta ao demonstrado no Capítulo II: a atividade cinematográfica possui uma característica intrínseca no que diz respeito à geração de receitas e remuneração de seus agentes. $\mathrm{O}$ primeiro elo remunerado é o exibidor, depois o distribuidor, e por fim, o produtor. Com este adiantamento da remuneração, diminuiu-se o incentivo do produtor a realizar projetos que tivessem apelo ao público nacional e que tivessem potencial mercadológico (AMANCIO, 2008).

Além destas observações, não foi elaborada nos governos FHC, uma política cinematográfica consistente capaz de gerar a convergência entre os elos da cadeia produtiva cinematográfica. A distribuição continuou hierarquizada pelos braços comerciais dos grandes estúdios dos EUA, as majors, que entre os anos 1994 e 2007, capturaram mais de $80 \%$ da renda de bilheteria (ANCINE, 2012). O elo exibidor, por sua vez, tornou-se dependente de um modelo de exibição altamente concentrador, na medida em que o novo conceito de exibição, multiplex, fica restrito basicamente a novos shoppings centers, localizados na maioria das circunstâncias nos grandes centros 
urbanos. Consequentemente, a despeito das políticas adotadas, a relação habitante/salas de cinema permaneceu elevada, em um cenário desvantajoso para o filme nacional, dada a hegemonia das obras de Hollywood nas salas de exibição. A cinematografia nacional retomou uma trajetória de produção, porém não obteve êxito na inserção das obras no mercado de distribuição e exibição nacionais.

A adoção nos Governos Lula de políticas de fomento calcadas em mecanismos que já visam a atingir toda a cadeia cinematográfica - e não somente o elo produtor; bem como já incorporam a dinâmica mais ampla e complexa da indústria audiovisual representam uma nova expectativa para o setor, através da modernização da dinâmica de produção cinematográfica nacional. No entanto, devido a sua introdução recente, os impactos destas novas políticas bem como a sua eficácia na inserção da indústria cinematográfica brasileira em um percurso de mercado ainda não podem ser mensurados.

A Figura 16 abaixo apresenta de forma esquemática o resumo do processo de consolidação da indústria cinematográfica no Brasil.

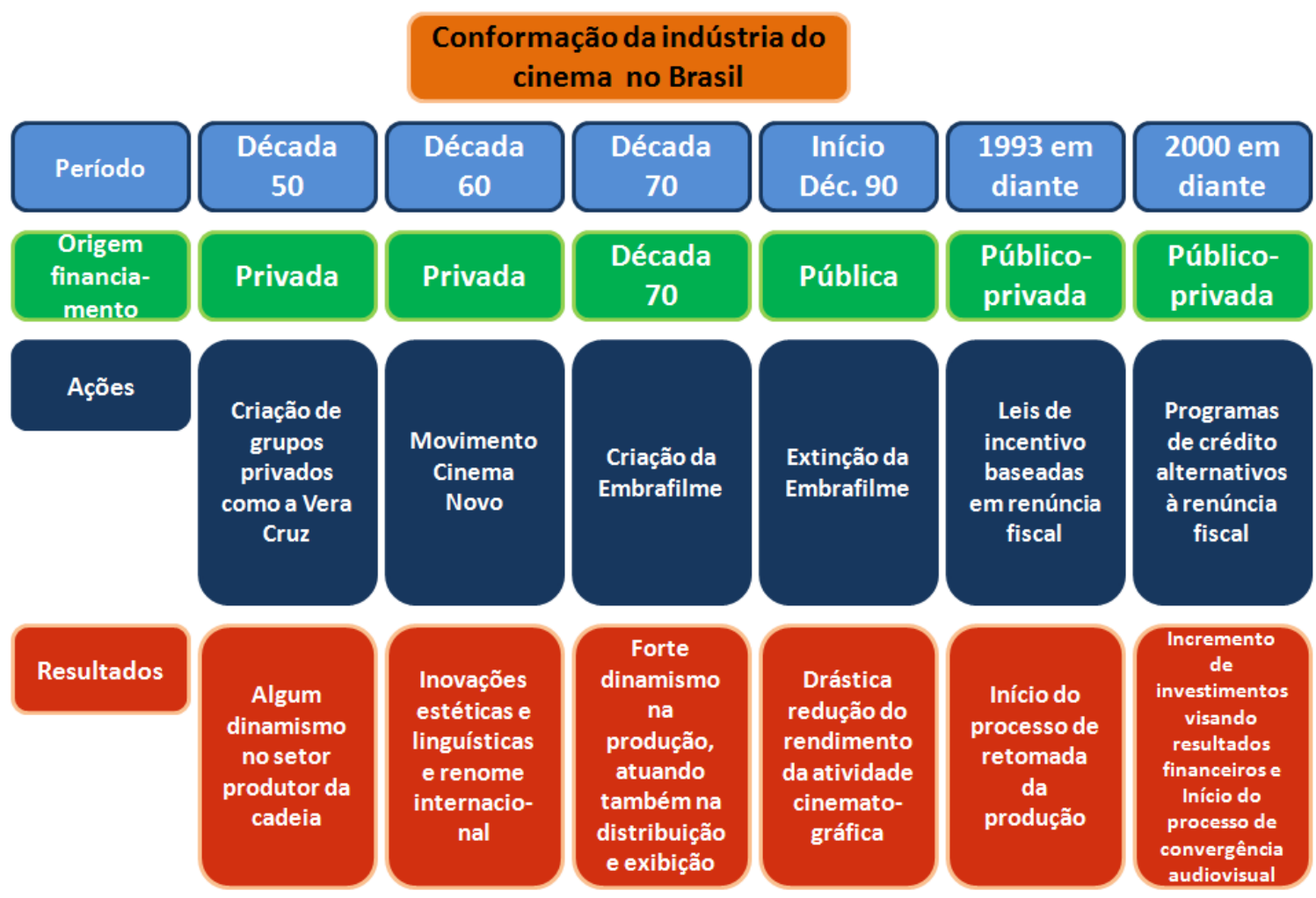

Figura 16: Conformação da indústria cinematográfica brasileira

Fonte: Elaboração própria a partir de MICHEL (2011) 
A despeito das inúmeras limitações enfrentadas desde o seu surgimento, a atividade cinematográfica brasileira assistiu ao longo de sua trajetória de consolidação a diversas tentativas de implementação de políticas visando a sua solidificação e afirmação. A origem do financiamento da atividade oscilou entre pública e privada tendo atingindo recentemente um perfil que conjuga estas duas naturezas de recursos.

O resultado no incremento da produção de obras foi visível em alguns momentos da cinematografia nacional, porém as limitações e incentivos errados das políticas impediram uma trajetória de desenvolvimento perene. Recentemente, com a incorporação da nova lógica audiovisual à atividade e adoção de políticas que visam a desenvolver o aspecto mercadológico das obras espera-se conduzir a indústria do cinema brasileiro a um percurso de desenvolvimento que não seja interrompido por restrições do modelo de fomento. 


\section{Conclusão}

A indústria cinematográfica da maior parte dos países possui, em maior ou menor grau, algum vínculo de dependência junto ao Estado. Atuando no sentido de cobrir as necessidades do setor, o Estado promove suas ações de acordo com o nível de desenvolvimento e carências da sua indústria cinematográfica.

Conforme evidenciado ao longo da presente dissertação, o Brasil possui um forte vínculo de dependência e apresenta elevada intervenção estatal na condução da atividade cinematográfica, cabendo ainda destacar que as políticas implementadas pelo Estado aplicam-se com ênfase maior no elo da produção.

Ao analisarmos as políticas públicas voltadas ao fomento da indústria de cinema no Brasil torna-se evidente que o apoio ao elo da distribuição foi ineficiente, o que não possibilitou a estruturação de uma dinâmica competitiva adequada de inserção das obras nacionais no mercado de exibição, além de não ter sido desenvolvido um programa de convergência audiovisual, que estabelecesse um vínculo entre os elos da indústria audiovisual nacional, fortalecendo o produto cinema e possibilitando o prolongamento do seu ciclo de vida através da sua inserção em outras janelas de exibição.

Alguns países tais como os EUA e a França já enxergam e atuam sobre a atividade audiovisual de maneira integrada há décadas, através da criação e adoção de políticas de convergência que visam o desenvolvimento da indústria cinematográfica conjuntamente aos demais elos da indústria audiovisual como a televisão e os demais suportes digitais.

Embora a indústria cinematográfica brasileira tenha assistido a uma evolução positiva do seu desempenho em alguns episódios da sua história - notadamente durante a era Embrafilme e a partir da Retomada; com aumento do número de obras produzidas e da competitividade impulsionados por mecanismos de incentivo diretos ou indiretos, os problemas histórico-estruturais da distribuição e da falta de sinergia entre a produção 
e distribuição cinematográfica e os demais elos de produção e comercialização de conteúdo audiovisual nacional permanecem uma realidade.

Além disso, embora tenha havido melhorias e ampliação da produção nacional nos últimos anos, estas não se deram à mesma proporção da evolução dos demais suportes de difusão e o acesso das obras cinematográficas brasileiras às janelas de exibição domésticas ainda é pouco representativo.

A superação da ineficiência do elo distribuidor da cadeia cinematográfica brasileira e da falta de sinergia entre os elos da cadeia audiovisual constitui um grande desafio e depende da articulação e da vontade política dos agentes atuantes na indústria e fora dela. Nos últimos anos, a questão do desenvolvimento da atividade audiovisual tem sido debatida e alternativas às experiências malsucedidas ou insuficientes têm sido propostas. A criação da TV Brasil - projeto de estruturação de rede televisiva pública nacional; e a promulgação em 4 de junho de 2011 da lei nº12.485 (ou Lei da TV Paga) com a proposta de remover barreiras à competição, valorizar a cultura nacional e gerar incentivos para uma dinâmica de produção e distribuição que favoreça o conteúdo audiovisual nacional são medidas adotadas neste sentido. 


\section{REFERÊNCIAS BIBLIOGRÁFICAS}

ANCINE - Agência Nacional de Cinema. Home Page Institucional. Disponível em: http://www.ancine.gov.br/ Acesso em Nov.2010

ANDERSSON, D., ANDERSSON, A. The Economics of Experiences, the Arts, and Entertainment. Northampton, Edward Elgar Publishing, 2006.

ALMEIDA, P. S; BUTCHER, P. Cinema, desenvolvimento e mercado. Rio de Janeiro, Aeroplano, 2003.

AMANCIO, T. Pacto Cinema e Estado: Os Anos EMBRAfILME. In: Embrafilme e o Cinema Brasileiro. São Paulo: Centro Cultural São Paulo, 2008.

AMRAM, M. The Value of Film Studios, Journal of Applied Corporate Finance, Volume 15 n. 2, 2002.

ARIAS, G. Principes et mode de fonctinnement des Sociétés de Financement de I'Industrie Cinématographique et de I'Audiovisuel. Association Cinéma au Soleil. Novembro 2005.

ARRUDA, M. A Política Cultural: regulação estatal e mecenato privado. Tempo social. vol.15 no.2 São Paulo Nov. 2003.

AUTRAN, A. O pensamento industrial cinematográfico brasileiro: ontem e hoje. In: Cinema e Mercado. São Paulo: Iniciativa Cultural. (Indústria Cinematográfica e Audiovisual Brasileira Vol.3), 2010.

BNDES - BANCO NACIONAL DO DESENVOLVIMENTO ECONÔMICO E SOCIAL. Home Page Institucional. Disponível em: http://www.bndes.gov.br/ Acesso em Nov.2011 
BAUMGaRTEN, P. A. ; FARBER, D. ; FLEISCHER, M. Producing, financing, and distributing film, 2nd ed., New York : Limelight Editions, 2004.

BAUMOL, W.; BOWEN, W. Performing arts: the economic dilemma. Massachussets: Yale University Press, 1969.

BENHAMOU, F. A economia da Cultura. São Paulo, Ateliê Editorial,2007.

BERNARDET, J.-C. O Que é Indústria Cinema. São Paulo: Brasiliense. 2001.

BERTINI, A. Economia da Cultura: a Indústria do entretenimento e o audiovisual no Brasil. São Paulo: Saraiva, 2008.

BONNELL, R. La vingt-cinquième image: une économie de l'audiovisuel. Gallimard, 4ème édition, 2006.

BORNER, W. Motion Picture Split Agreements: An Antitrust Analysis, 52 Fordham Law Revue, 159, 1983

BOURGUIGNON, Y. Leis de Incentivo à Cultura (Lei Rouanet e Lei do Audiovisual) e Patrocínio: incentivo efetivo à cultura ou mera ferramenta mercadológica? Disponível em: http://integracao.fgvsp.br/ano7/01/opiniao.htm Acesso em Abr. 2012.

BRASIL. Lei no 12.485, de 12 de setembro de 2011. Dispõe sobre a comunicação audiovisual de acesso condicionado. Disponível em: http://www.planalto.gov.br/ccivil_03/_Ato2011-2014/2011/Lei/L12485.htm Acesso em Jun. 2012.

BRITZ, I; BRAGA, R.; DE LUCA, L. Film business: o negócio do cinema. Rio de Janeiro, Elsevier, 2010.

CAVES, R. Creative industries: contracts between art and commerce. Cambridge: Harvard University Press, 2000. 
Centre National de la Cinématographie (CNC). Les SOFICA : Un dispositif original de financement du cinéma et de l'audiovisuel, Outubro 2008. Disponível em :

http://www.cnc.fr/CNC_GALLERY_CONTENT/DOCUMENTS/Dossiers_commis sions/cinema/les_SOFICA/SOFICA_presentation_gen/Sofica_Presentation_gen e_08.pdf Acesso em: Mar. 2012.

CESNIK, F \& BELTRAME, P. Globalização da cultura. Barueri, SP: Manole, 2005.

Code de l'industrie Cinématographique. Disponível em :

http://www.ancine.gov.br/cgi/cgilua.exe/sys/start.htm?sid=74 Acesso em: Abr. 2012.

COUTO, F. Gerenciamento de projetos no âmbito da Economia Criativa Um estudo de caso das "incubadoras Rio Criativo". Dissertação de Mestrado - Departamento de Engenharia Industrial, PUC-Rio, Rio de Janeiro, 2011.

DA SILVA, E. R. A Sofisticação da Gestão e o direcionamento estratégico no Setor de Cinema: um estudo exploratório no segmento produtor. Dissertação de Mestrado - Programa de Pós-Graduação em Administração, Instituto COPPEAD de Administração, Universidade Federal do Rio de Janeiro. Rio de Janeiro, 2005.

Datafolha - Instituto de Pesquisas. Projeto Cinema - Estudo qualitativo, Abril/Maio 2008.

DEBANDE, O.; CHETRIT, G. The European Audiovisual Industry: anoverview. European Investment Bank, Setembro 2001.

DINIZ, S. C. Análise do setor cultural nas regiões metropolitanas. Disponível em: http://www.anpec.org.br/encontro2008/artigos/200807211651060-.pdf Acesso Dez. 2009. 
DOYLE, G. Understanding media economics. SAGE Publications, Trowbridge, Wiltshire, 2002.

Economia do Cinema no Brasil. Pesquisa Desenvolvida pelo Ministério da Cultura, Brasil, 1997 ou $1998 . \quad$ Disponível em http://www9.cultura.gov.br/relats/relats.htm Acesso 20 de maio 2012

FARCHY, J. L'industrie du cinéma. Que sais-je? Presses Universitaires de France, Paris, 2004.

FIGUEIRÔA, A. (2008). Cinema Novo, a luta por uma estética nacional. Rede de Memória Virtual. Disponível em < http://bndigital.bn.br/redememoria/cinovo.html> Acesso em Out. 2010.

FILMEB. Dados de Mercado. Disponível em < www.filmeb.com.br> Acesso em Nov. 2011.

FIRJAN. A cadeia da Indústria Criativa no Brasil. Disponível em: http://www.firjan.org.br/main.jsp?lumltemld=2C908CE9215B0DC40121737B1C 8107C1\&lumPageld=2C908CE9215B0DC40121793770A2082A Acesso em Nov. 2011.

FLORIDA, R. et al. That's Entertainement: Scale and Scope Economies in the Location and Clustering of the Entertainement Economy. The Royal Institute of technology, Centre of Excellence for Science and Innovation Studies (CESIS), 2009.

FOREST, C. L'argent du cinéma: Introduction à I'économie du septième art. Editions Belin, Paris, 2002.

FREEMAN, E. Strategic Management: A Stakeholder Approach. Cambridge University Press, 1984.

GODOY, A. Introdução à pesquisa qualitative e suas possibilidades. RAE Revista de Administração de Empresas, São Paulo, v. 35, n. 2, p. 57-63, 1995. 
GOLDMAN, W. Adventures in the Screen Trade: A Personal View of Hollywood and Screenwriting. Warner Books, 1989.

GOMES, P. Cinema: Trajetória no Subdesenvolvimento. $2^{\underline{a}}$ ed. São Paulo: Paz e Terra, 1996.

GORGULHO, L. et al. A Economia da Cultura, o BNDES e o desenvolvimento sustentável. [Editorial]. BNDES Setorial, nํ30, p.299 - 352, mar/set 2009.

GORGULHO, L. O papel do BNDES no fomento ao setor audiovisual: depoimento. [setembro de 2009] Rio de Janeiro: Revista FilmeB. Entrevista concedida a Pedro Butcher.

IKEDA, M. Estado e cinema no início do século XXI: Características de formação da Ancine. Fundação Casa de Rui Barbosa, 2011.

INSTITUTO BRASILEIRO DE GEOGRAFIA E ESTATÍSTICA. Sistema de Informações e Indicadores Culturais 2003-2005. Disponível em: <http://www.ibge.gov.br/home/estatistica/populacao/indic_culturais/2005> Acesso em Out. 2010.

JOHNSON, R. The Film Industry in Brazil: Culture and State. Pittsburgh: University of Pittsburgh Press, 1987.

JORGE, W. 1949/1954: um sonho do cinema brasileiro. Ciencia e Cultura. 2004, vol.56, n.3, pp. 54-55

LANGE, A. et al. Les aides publiques aux œuvres cinématographiques et audiovisuelles en Europe - Une analyse comparative. Observatoire Européen de l'Audiovisuel, Banque européenne d’investissement, Strasbourg, 2004.

LECLERC, J. P. Réflexions sur le dispositif français de soutien à la production cinématographique - Rapport établi à la demande du ministre de la culture et de la communication, Janeiro 2003. 
MAILLARD, D. Les SOFICA sont-elles un bon placement? (EF-GP). Document de recherche. Conservatoire National des Arts et Métiers (CNAM), Dezembro 2005.

MANNONI, L. The great art of light and shadow: archaeology of the cinema. Exeter Studies in Film History: University of Exeter Press, 2000.

MARQUES, P. H. M. Modelos de financiamento da indústria cinematográfica: 0 caso brasileiro pós-Embrafilme. Dissertação de Mestrado - Instituto de Economia, Universidade Estadual de Campinas, Campinas, 2008.

MARQUES, P. H. O Papel do BNDES no fortalecimento da cadeia produtiva cinematográfica. Monografia de conclusão do curso de especialização em Economia e Regulação Audiovisual. Universidade Federal do Rio de Janeiro, Rio de Janeiro, 2009.

MARSON, M. Cinema e políticas de estado, da Embrafilme à Ancine. São Paulo. Iniciativa Cultural. (Indústria Cinematográfica e Audiovisual Brasileira Vol.1), 2010.

MATTA, J. P. Análise Competitiva da Indústria Cinematográfica Brasileira no Mercado Interno de Salas de Exibição, de 1994 a 2003. 2004. 296 f. Dissertação (Mestrado em Administração) - Escola de Administração, Universidade Federal da Bahia, Salvador, 2004.

MATTA, J. P. Políticas Públicas federais de apoio à indústria cinematográfica brasileira: um histórico de ineficácia na distribuição. In: Cinema e Mercado. São Paulo. Iniciativa Cultural. (Indústria Cinematográfica e Audiovisual Brasileira Vol.3), 2010.

MINISTÉRIO DA CULTURA - MINC. Nova Lei da Cultura. Disponível em: http://www.cultura.gov.br/site/2010/01/28/lei-rouanet-12/ Acesso em Out. de 2012. 
MPAA. The Motion Picture Association of America. Home Page Institucional Disponível em http://www.mpaa.org Acesso em Jan. 2012.

ORTIZ, J.M, Cinema, Estado e Lutas Culturais, anos 50/60/70. Rio de Janeiro: Paz e Terra, 1983.

REIS, Ana Carla. Economia da Cultura e desenvolvimento sustentável: o caleidoscópio da cultura. São Paulo: Manole, 2007.

RODRIGO, M. Imagens Poderosas. Gazeta Mercantil, São Paulo e Gramado, p.1, 21 de setembro 2007.

ROSENFELD, A. Cinema: Arte \& Indústria. São Paulo: Editora Perspectiva, 2002.

SÁ EARP, F. Pão e Circo: Problemas e perspectivas da economia do entretenimento. Rio de Janeiro: Razão Cultural, 2002.

SÁ EARP, F; GUIMARÃES, R. Incentivando a produção de "blockbusters" no Brasil. In Cinema e Economia Política. São Paulo. Iniciativa Cultural. (Indústria Cinematográfica e Audiovisual Brasileira Vol.2), 2010.

SANDOT, F. Méthode de Financement et rentabilité dans la Production Cinématographique : les SOFICAS. Paris, Maio 2006. Trabalho de Pesquisa de Final de Curso Ecole des Hautes Etudes Commerciales Paris HEC.

SARKOVAS, Y. (2005). O Incentivo Fiscal à Cultura no Brasil. Revista D'Art. Centro Cultural São Paulo. Disponível em:

http://www.centrocultural.sp.gov.br/revista_dart/pdfs/dart12\%200\%20incentivo \%20fiscal\%20\%C3\%A0\%20cultura\%20no\%20brasil.pdf Acesso em Jan. 2012

SIMIS, A. Estado e Cinema no Brasil. 2ª̂ed. São Paulo: Annablume, 2008.

SQUIRE, J. The Movie Business Book. 3ㄹed. Fireside, 2004. 
STEBBINS, R. Exploratory Research in the Social Sciences. Sage University Papers Series on Qualitative Research Methods, Vol. 48. Thousand Oaks, California, 2001.

The final frontier: How digital technology is changing the way cinemas work. The Economist, Los Angeles, 12 de Julho 2007.

THROSBY, D. (Department of Economics, Macquarie University, Sydney, Australia). Determining the Value of Cultural Goods: How Much (or How Little) Does Contingent Valuation Tell Us? Journal of Cultural Economics 27, 2003. 275-285 p.

United Nations, UNCTAD/DITC/2008/2. Creative Economy Report 2008. (Todos os direitos reservados), 2008.

VERON, L. (1999). The competitive advantage of Hollywood industry. Columbia International Affairs on Line. Disponível em $<$ https//www.cc.columbia.edu/sec/dlc/ ciao/wps/ve101 Acesso em 4 de outubro de 2010.

VOGEL., H. Entertainment Industry Economics: a guide for financial analysis. New York, Cambridge University Press. 1998.

DE VANY, A. Hollywood Economics: How Extreme Uncertainty Shapes the Film Industry. Routledge, 2004.

WALCK, C. Hand-book on Statistical Distributions for experimentalists. University of Stockholm, 2007.

ZAVERUCHA, V. Lei do Audiovisual Passo a Passo. Edição da Autora, 1996. 


\section{APÊNDICE}

Tabela 5: Dados gerais do mercado brasileiro

\begin{tabular}{|c|c|c|c|c|}
\hline \multicolumn{5}{|c|}{ Dados gerais do mercado brasileiro } \\
\hline \multicolumn{5}{|c|}{ Números Gerais População Brasil } \\
\hline Indicador & 2008 & 2009 & 2010 & 2011 \\
\hline População & 183.987 .291 & 191.480 .130 & 190.755 .799 & 192.379.287 \\
\hline Número de Habitantes nas capitais & 44.222 .828 & 45.427 .851 & 45.466 .045 & 45.466 .045 \\
\hline Número de Municípios & 5.564 & 5.565 & 5.565 & 5.565 \\
\hline $\begin{array}{l}\text { Número de Municípios com mais de } 1 \text { milhão } \\
\text { de habitantes }\end{array}$ & 14 & 14 & 15 & 15 \\
\hline $\begin{array}{l}\text { Número de habitantes em Municípios com } \\
\text { mais de } 1 \text { milhão de habitantes }\end{array}$ & 38.465 .981 & 39.458 .578 & 40.135 .344 & 40.135 .344 \\
\hline \multicolumn{5}{|c|}{ Dados econômicos } \\
\hline Indicador & 2008 & 2009 & 2010 & 2011 \\
\hline PIB & $\mathrm{R} \$ 3,032$ trilhões & $\mathrm{R} \$ 3,239$ trilhões & $\mathrm{R} \$ 3,770$ trilhões & $\mathrm{R} \$ 4,143$ trilhões \\
\hline Renda per Capita & $\mathrm{R} \$ 15.991,65$ & $\mathrm{R} \$ 16.917,66$ & $\mathrm{R} \$ 19.508,59$ & $\mathrm{R} \$ 21.252,00$ \\
\hline Salario Mínimo Nacional & $\begin{array}{c}\mathrm{R} \$ 415,00 \\
(\mathrm{março/2008} \mathrm{a} \\
\text { janeiro/2009) }\end{array}$ & $\mathrm{R} \$ 465,00$ & $\mathrm{R} \$ 510,00$ & $\mathrm{R} \$ 545,00$ \\
\hline Valor médio do dolar & $\mathrm{R} \$ 1,84$ & $\mathrm{R} \$ 2,00$ & $\mathrm{R} \$ 1,76$ & $\mathrm{R} \$ 1,67$ \\
\hline
\end{tabular}

Fonte: ANCINE (2012) 
Tabela 6: Dados básicos do mercado cinematográfico brasileiro

\begin{tabular}{|c|c|c|c|c|}
\hline \multicolumn{5}{|c|}{ Dados básicos do Mercado } \\
\hline Indicador & 2008 & 2009 & 2010 & 2011 \\
\hline Público em salas de exibição & 89.960 .164 & 112.665.601 & 134.364 .520 & 143.886.208 \\
\hline Público filme nacional em salas de exibição & 9.143 .052 & 16.070 .368 & 25.227 .757 & 17.869 .385 \\
\hline Público filme estrangeiro em salas de exibição & 80.817 .112 & 96.595 .233 & 109.136 .763 & 126.016 .823 \\
\hline Renda Bruta em salas de exibição & $\mathrm{R} \$ 729.522 .782,41$ & $\mathrm{R} \$ 969.744 .934,14$ & $\mathrm{R} \$ 1.256 .550 .704,09$ & $\mathrm{R} \$ 1.437 .801 .236,00$ \\
\hline $\begin{array}{c}\text { Renda Bruta em salas de exibição filmes } \\
\text { nacionais }\end{array}$ & $\mathrm{R} \$ 70.244 .803,07$ & $\mathrm{R} \$ 131.873 .775,25$ & $\mathrm{R} \$ 222.169 .100,11$ & $\mathrm{R} \$ 163.270 .076,00$ \\
\hline $\begin{array}{c}\text { Renda Bruta em salas de exibição filmes } \\
\text { estrangeiros }\end{array}$ & $\mathrm{R} \$ 659.277 .979$ & $\mathrm{R} \$ 837.871 .158,89$ & $\mathrm{R} \$ 1.034 .381 .603,98$ & $\mathrm{R} \$ 1.274 .531 .160,00$ \\
\hline Número de filmes lançados em salas & 323 & 319 & 303 & 339 \\
\hline $\begin{array}{c}\text { Número de filmes nacionais lançados em } \\
\text { salas }\end{array}$ & 79 & 84 & 75 & 99 \\
\hline $\begin{array}{l}\text { Número de filmes estrangeiros lançados em } \\
\text { salas }\end{array}$ & 244 & 235 & 228 & 240 \\
\hline $\begin{array}{c}\text { Número de obras lançadas em vídeo } \\
\text { doméstico }\end{array}$ & 1.537 & 1.028 & 1.013 & 1.13 \\
\hline $\begin{array}{l}\text { Número de obras nacionais lançadas em vídeo } \\
\text { doméstico }\end{array}$ & 78 & 104 & 89 & 89 \\
\hline $\begin{array}{l}\text { Número de obras estrangeiras lançadas em } \\
\text { vídeo doméstico }\end{array}$ & 1.459 & 924 & 924 & 1.041 \\
\hline Número de salas de exibição & 2.278 & 2.141 & 2.206 & 2.352 \\
\hline Número de complexos & 816 & 674 & 662 & 686 \\
\hline $\begin{array}{l}\text { Número de indivíduos nos domicílios com } \\
\text { televisores }\end{array}$ & 50.520 .000 & 53.384 .000 & 57.644 .409 & 57.736 .046 \\
\hline Número de canais de TV por assinatura ${ }^{1}$ & 106 & 118 & 116 & 165 \\
\hline Número de assinantes de TV por assinatura ${ }^{2}$ & 6,3 milhões & 7,449 milhões & 9,768 milhões & 12,744 milhões \\
\hline $\begin{array}{l}\text { Número de redes de TV aberta (cabeças de } \\
\text { rede) }\end{array}$ & 34 & 34 & 62 & 91 \\
\hline Número de celulares & 150,6 milhões & 174,0 milhões & 202,9 milhões & 242,2 milhões \\
\hline \multicolumn{5}{|c|}{ Índices básicos do Mercado Audiovisual } \\
\hline Indicador & 2008 & 2009 & 2010 & 2011 \\
\hline Habitantes por sala & 80.297 & 89.435 & 86.471 & 81.794 \\
\hline Ingressos per capita & 0,42 & 0,59 & 0,70 & 0,75 \\
\hline Preço médio do ingresso & $\mathrm{R} \$ 8,11$ & $\mathrm{R} \$ 8,61$ & $\mathrm{R} \$ 9,35$ & $\mathrm{R} \$ 9,99$ \\
\hline $\begin{array}{l}\text { Participação de público do filme nacional em } \\
\text { salas }\end{array}$ & $10,2 \%$ & $14,3 \%$ & $18,8 \%$ & $12,4 \%$ \\
\hline $\begin{array}{l}\text { Lançamentos de filmes nacionais em salas } \\
\text { sobre o total }\end{array}$ & $24,5 \%$ & $26,3 \%$ & $24,8 \%$ & $29,2 \%$ \\
\hline
\end{tabular}

$\mathrm{ND}=$ não disponível.

1. Não foram considerados os canais pay-per-view, canais de áudio, interativos, televendas, canais abertos e canais locais.

2. Este número corresponde ao conjunto de assinantes de cabo, MMDS e DTH.

Fonte: ANCINE (2012) 
Tabela 7: Três principais bilheterias por ano (1995 - 2010)

\begin{tabular}{|c|c|c|c|c|c|c|c|}
\hline $\begin{array}{c}\text { Ano de } \\
\text { Lançamento }\end{array}$ & Título & Diretor & $\begin{array}{c}\text { Proponente / } \\
\text { Produtora }\end{array}$ & UF & Distribuidora & Renda (R\$) & Público \\
\hline 2010 & Chico Xavier & Daniel Filho & Lereby Produções & RJ & $\begin{array}{l}\text { Sony/Disney } \\
\text { (Columbia) }\end{array}$ & $30,279,033.00$ & $3,412,969$ \\
\hline 2010 & Nosso Lar & $\begin{array}{l}\text { Wagner de } \\
\text { Assis }\end{array}$ & $\begin{array}{c}\text { Cinética Filmes e } \\
\text { Produções }\end{array}$ & RJ & Fox & $36,126,083.00$ & $4,060,304$ \\
\hline 2010 & $\begin{array}{c}\text { Tropa de Elite } \\
2\end{array}$ & José Padilha & $\begin{array}{l}\text { Zazen Produções } \\
\text { Audiovisuais }\end{array}$ & RJ & Zazen & $102,320,114.16$ & $11,023,475$ \\
\hline 2009 & $\begin{array}{l}\text { A Mulher } \\
\text { Invisível }\end{array}$ & $\begin{array}{l}\text { Cláudio } \\
\text { Torres }\end{array}$ & Conspiração Filmes & RJ & Warner & $20,498,576.00$ & $2,353,136$ \\
\hline 2009 & Os Normais 2 & $\begin{array}{c}\text { José } \\
\text { Alvarenga Jr. }\end{array}$ & Globo Filmes & RJ & Imagem & $18,978,259.88$ & $2,202,640$ \\
\hline 2009 & $\begin{array}{c}\text { Se Eu Fosse } \\
\text { Você } 2\end{array}$ & Daniel Filho & $\begin{array}{c}\text { Total } \\
\text { Entertainment }\end{array}$ & RJ & Fox & $50,543,885.00$ & $6,112,851$ \\
\hline 2008 & $\begin{array}{l}\text { Ensaio Sobre a } \\
\text { Cegueira }\end{array}$ & $\begin{array}{l}\text { Fernando } \\
\text { Meirelles }\end{array}$ & $\begin{array}{l}\text { O2 Produções } \\
\text { Artísticas e } \\
\text { Cinematográficas }\end{array}$ & SP & Fox & $7,772,105.00$ & 904,514 \\
\hline 2008 & $\begin{array}{l}\text { Meu Nome } \\
\text { não É Johnny }\end{array}$ & Mauro Lima & $\begin{array}{c}\text { Atitude Produções } \\
\text { e } \\
\text { Empreendimentos }\end{array}$ & RJ & Sony/ Downtown & $18,092,043.00$ & $2,099,294$ \\
\hline 2008 & $\begin{array}{c}\text { O Guerreiro } \\
\text { Didi e a Ninja } \\
\text { Lili }\end{array}$ & $\begin{array}{l}\text { Marcus } \\
\text { Figueiredo }\end{array}$ & Diler \& Associados & RJ & Disney & $2,996,388.00$ & 647,555 \\
\hline 2007 & $\begin{array}{l}\text { A Grande } \\
\text { Família - o } \\
\text { Filme }\end{array}$ & $\begin{array}{l}\text { Maurício } \\
\text { Farias }\end{array}$ & Globo Filmes & RJ & Europa/MAM & $15,482,240.00$ & $2,035,576$ \\
\hline 2007 & O Primo Basílio & Daniel Filho & Lereby Produções & RJ & Buena Vista & $6,376,703.00$ & 838,726 \\
\hline 2007 & Tropa de Elite & José Padilha & $\begin{array}{l}\text { Zazen Produções } \\
\text { Audiovisuais }\end{array}$ & RJ & Universal & $20,395,447.00$ & $2,417,754$ \\
\hline 2006 & $\begin{array}{c}\text { Didi, o Caçador } \\
\text { de Tesouros }\end{array}$ & $\begin{array}{c}\text { Marcus } \\
\text { Figueiredo }\end{array}$ & Diler \& Associados & RJ & Buena Vista & $6,220,016.00$ & $1,024,732$ \\
\hline 2006 & $\begin{array}{c}\text { Se eu Fosse } \\
\text { Você }\end{array}$ & Daniel Filho & $\begin{array}{c}\text { Total } \\
\text { Entertainment }\end{array}$ & RJ & Fox & $28,916,137.00$ & $3,644,956$ \\
\hline 2006 & Xuxa Gêmeas & $\begin{array}{c}\text { Jorge } \\
\text { Fernando }\end{array}$ & Diler \& Associados & RJ & Fox & $5,801,734.00$ & $1,007,490$ \\
\hline 2005 & $\begin{array}{l}\text { Dois Filhos de } \\
\text { Francisco: a } \\
\text { História de } \\
\text { Zezé Di } \\
\text { Camargo \& } \\
\text { Luciano }\end{array}$ & $\begin{array}{l}\text { Breno } \\
\text { Silveira }\end{array}$ & Conspiração Filmes & RJ & Columbia & $36,728,278.00$ & $5,319,677$ \\
\hline 2005 & $\begin{array}{l}\text { O Casamento } \\
\text { de Romeu e } \\
\text { Julieta }\end{array}$ & $\begin{array}{l}\text { Bruno } \\
\text { Barreto }\end{array}$ & Filmes do Equador & RJ & Buena Vista & $7,303,657.00$ & 969,278 \\
\hline 2005 & $\begin{array}{l}\text { Tainá } 2 \text { - a } \\
\text { Aventura } \\
\text { Continua }\end{array}$ & Mauro Lima & $\begin{array}{l}\text { Tietê Produções } \\
\text { Cinematográficas }\end{array}$ & RJ & Columbia & $4,612,264.00$ & 788,442 \\
\hline 2004 & $\begin{array}{c}\text { Cazuza - o } \\
\text { Tempo Não } \\
\text { Para }\end{array}$ & $\begin{array}{c}\text { Sandra } \\
\text { Werneck e } \\
\text { Walter } \\
\text { Carvalho }\end{array}$ & Lereby Produções & RJ & Columbia & $21,230,606.00$ & $3,082,522$ \\
\hline 2004 & Olga & $\begin{array}{c}\text { Jayme } \\
\text { Monjardim }\end{array}$ & $\begin{array}{c}\text { Nexus Cinema e } \\
\text { Vídeo }\end{array}$ & $\mathrm{SP}$ & Lumière & $20,375,397.00$ & $3,078,030$ \\
\hline 2004 & $\begin{array}{l}\text { Sexo, Amor e } \\
\text { Traição }\end{array}$ & $\begin{array}{c}\text { Jorge } \\
\text { Fernando }\end{array}$ & $\begin{array}{c}\text { Total } \\
\text { Entertainment }\end{array}$ & RJ & Fox & $15,775,132.00$ & $2,219,423$ \\
\hline 2003 & Carandiru & $\begin{array}{c}\text { Hector } \\
\text { Babenco }\end{array}$ & HB Filmes & $\mathrm{SP}$ & Columbia & $29,623,481.00$ & $4,693,853$ \\
\hline 2003 & $\begin{array}{l}\text { Lisbela e o } \\
\text { Prisioneiro }\end{array}$ & Guel Arraes & $\begin{array}{c}\text { Natasha } \\
\text { Enterprises }\end{array}$ & RJ & Fox & $19,915,933.00$ & $3,174,643$ \\
\hline 2003 & Os Normais & $\begin{array}{c}\text { José } \\
\text { Alvarenga Jr. }\end{array}$ & $\begin{array}{c}\text { Missão Impossível } \\
\text { Cinco Produções } \\
\text { Artísticas }\end{array}$ & $\mathrm{RJ}$ & Lumière & $19,874,866.00$ & $2,996,467$ \\
\hline 2002 & Avassaladoras & $\begin{array}{l}\text { Mara } \\
\text { Mourão }\end{array}$ & $\begin{array}{c}\text { Total } \\
\text { Entertainment }\end{array}$ & RJ & Fox & $1,722,883.00$ & 310,260 \\
\hline 2002 & $\begin{array}{l}\text { Cidade de } \\
\text { Deus }\end{array}$ & $\begin{array}{l}\text { Fernando } \\
\text { Meirelles }\end{array}$ & O2 Filmes Curtos & $\mathrm{SP}$ & Lumière & $19,066,087.00$ & $3,370,871$ \\
\hline
\end{tabular}




\begin{tabular}{|c|c|c|c|c|c|c|c|}
\hline 2002 & $\begin{array}{l}\text { Xuxa e os } \\
\text { Duendes } 2\end{array}$ & $\begin{array}{l}\text { Paulo Sérgio } \\
\text { Almeida e } \\
\text { Rogério } \\
\text { Gomes } \\
\end{array}$ & Diler \& Associados & RJ & Warner & $11,485,979.00$ & $2,301,152$ \\
\hline 2001 & A Partilha & Daniel Filho & Lereby Produções & RJ & Columbia & $8,797,925.00$ & $1,449,411$ \\
\hline 2001 & $\begin{array}{l}\text { Tainá - uma } \\
\text { Aventura na } \\
\text { Amazônia }\end{array}$ & $\begin{array}{c}\text { Tânia } \\
\text { Lamarca e } \\
\text { Sérgio Bloch } \\
\end{array}$ & $\begin{array}{l}\text { Tietê Produções } \\
\text { Cinematográficas }\end{array}$ & RJ & Art Filmes/ MAM & $3,054,492.00$ & 853,210 \\
\hline 2001 & $\begin{array}{l}\text { Xuxa e os } \\
\text { Duendes }\end{array}$ & $\begin{array}{l}\text { Paulo Sérgio } \\
\text { Almeida e } \\
\text { Rogério } \\
\text { Gomes } \\
\end{array}$ & Diler \& Associados & RJ & Warner & $11,691,200.00$ & $2,657,091$ \\
\hline 2000 & Eu, tu, eles & $\begin{array}{c}\text { Andrucha } \\
\text { Waddington }\end{array}$ & Conspiração Filmes & RJ & Columbia & $4,111,481.00$ & 695,682 \\
\hline 2000 & $\begin{array}{c}\text { O Auto da } \\
\text { Compadecida }\end{array}$ & Guel Arraes & Globo Filmes & RJ & Columbia & $11,496,994.00$ & $2,157,166$ \\
\hline 2000 & Xuxa Popstar & $\begin{array}{c}\text { Paulo Sérgio } \\
\text { Almeida e } \\
\text { Tizuka } \\
\text { Yamasaki } \\
\end{array}$ & Diler \& Associados & RJ & Warner & $9,625,191.00$ & $2,394,326$ \\
\hline 1999 & Orfeu & $\begin{array}{c}\text { Cacá } \\
\text { Diegues }\end{array}$ & $\begin{array}{l}\text { Rio Vermelho } \\
\text { Filmes }\end{array}$ & RJ & Warner & $4,455,409.00$ & 961,961 \\
\hline 1999 & Xuxa Requebra & $\begin{array}{c}\text { Tizuka } \\
\text { Yamazaki }\end{array}$ & Diler \& Associados & RJ & Fox & $8,173,376.00$ & $2,074,461$ \\
\hline 1999 & Zoando na TV & $\begin{array}{c}\text { José } \\
\text { Alvarenga Jr. }\end{array}$ & $\begin{array}{c}\text { Globo Filmes / } \\
\text { Angélica Produções } \\
\text { Artísticas / Lereby } \\
\text { Produções }\end{array}$ & RJ & Columbia & $3,463,297.00$ & 911,394 \\
\hline 1998 & $\begin{array}{l}\text { Central do } \\
\text { Brasil }\end{array}$ & Walter Salles & $\begin{array}{l}\text { Videofilmes } \\
\text { Produções } \\
\text { Artísticas } \\
\end{array}$ & RJ & $\begin{array}{l}\text { S. Ribeiro/ } \\
\text { Riofilme }\end{array}$ & $8,087,276.00$ & $1,593,967$ \\
\hline 1998 & $\begin{array}{c}\text { Menino } \\
\text { Maluquinho } 2\end{array}$ & $\begin{array}{l}\text { Fernando } \\
\text { Meirelles e } \\
\text { Fabrizia } \\
\text { Alves Pinto }\end{array}$ & $\begin{array}{l}\text { Grupo Novo de } \\
\text { Cinema e TV }\end{array}$ & RJ & $\begin{array}{l}\text { S. Ribeiro/ } \\
\text { Riofilme }\end{array}$ & $898,496.00$ & 367,456 \\
\hline 1998 & $\begin{array}{l}\text { Simão, o } \\
\text { Fantasma } \\
\text { Trapalhão }\end{array}$ & $\begin{array}{l}\text { Paulo } \\
\text { Aragão }\end{array}$ & $\begin{array}{c}\text { Renato Aragão } \\
\text { Produções } \\
\text { Artísticas } \\
\end{array}$ & RJ & Columbia & $6,118,522.00$ & $1,658,136$ \\
\hline 1997 & $\begin{array}{l}\text { Guerra de } \\
\text { Canudos }\end{array}$ & $\begin{array}{c}\text { Sérgio } \\
\text { Rezende }\end{array}$ & Morena Filmes & RJ & Columbia & $2,725,130.00$ & 655,016 \\
\hline 1997 & $\begin{array}{l}\text { O Noviço } \\
\text { Rebelde }\end{array}$ & $\begin{array}{c}\text { Tizuka } \\
\text { Yamazaki }\end{array}$ & $\begin{array}{c}\text { Renato Aragão } \\
\text { Produções } \\
\text { Artísticas } \\
\end{array}$ & RJ & $\begin{array}{l}\text { Columbia/ Art } \\
\text { Filmes }\end{array}$ & $6,019,150.00$ & $1,501,035$ \\
\hline 1997 & $\begin{array}{c}\text { Pequeno } \\
\text { Dicionário } \\
\text { Amoroso }\end{array}$ & $\begin{array}{c}\text { Sandra } \\
\text { Werneck }\end{array}$ & $\begin{array}{l}\text { Cineluz Produções } \\
\text { Cinematográficas }\end{array}$ & RJ & Lumière/ Riofilme & $2,100,685.00$ & 402,430 \\
\hline 1996 & Jenipapo & $\begin{array}{c}\text { Monique } \\
\text { Gardenberg }\end{array}$ & $\begin{array}{c}\text { Dueto Produções e } \\
\text { Publicidade }\end{array}$ & RJ & Riofilme & $350,000.00$ & 72,133 \\
\hline 1996 & $\begin{array}{l}\text { Tieta do } \\
\text { Agreste }\end{array}$ & $\begin{array}{c}\text { Cacá } \\
\text { Diegues }\end{array}$ & $\begin{array}{l}\text { Sky Light Cinema } \\
\text { Foto e Art }\end{array}$ & RJ & Columbia & $2,380,586.00$ & 511,954 \\
\hline 1996 & $\begin{array}{c}\text { Todos os } \\
\text { Corações do } \\
\text { Mundo } \\
\end{array}$ & Murilo Salles & $\begin{array}{l}\text { Sports Target } \\
\text { Media }\end{array}$ & RJ & S. Ribeiro & $1,004,415.00$ & 265,017 \\
\hline 1995 & $\begin{array}{c}\text { Carlota } \\
\text { Joaquina, } \\
\text { Princesa do } \\
\text { Brazil } \\
\end{array}$ & $\begin{array}{c}\text { Carla } \\
\text { Camurati }\end{array}$ & $\begin{array}{l}\text { Elimar Produções } \\
\text { Artísticas }\end{array}$ & RJ & Elimar & $6,430,000.00$ & $1,286,000$ \\
\hline 1995 & $\begin{array}{c}\text { Menino } \\
\text { Maluquinho }\end{array}$ & $\begin{array}{l}\text { Helvécio } \\
\text { Ratton }\end{array}$ & $\begin{array}{c}\text { Grupo Novo de } \\
\text { Cinema e TV }\end{array}$ & RJ & $\begin{array}{l}\text { S. Ribeiro/ } \\
\text { Riofilme }\end{array}$ & $1,532,509.00$ & 397,023 \\
\hline 1995 & O Quatrilho & $\begin{array}{l}\text { Fábio } \\
\text { Barreto }\end{array}$ & $\begin{array}{l}\text { Filmes do Equador } \\
\text { / Produções } \\
\text { Cinematográficas } \\
\text { LC Barreto }\end{array}$ & RJ & S. Ribeiro & $4,513,302.00$ & $1,117,154$ \\
\hline
\end{tabular}

Fonte: Elaboração própria a partir de ANCINE (2012) 